\author{
Universidade de São Paulo \\ Instituto de Física de São Carlos \\ Departamento de Física e Ciências dos Materiais \\ Grupo de Computação Interdisciplinar
}

CARLOS DORO NETO

Reconstrução e análise comparativa de canais de Volkmann e Havers utilizando redes complexas

São Carlos

2015 

CARLOS DORO NETO

\title{
Reconstrução e análise comparativa de canais de Volkmann e Havers utilizando redes complexas
}

\author{
Dissertação apresentada ao Programa de Pós- \\ Graduação em Física do Instituto de Física de \\ São Carlos da Universidade de São Paulo, para a \\ obtenção do título de Mestre em Ciências. \\ Área de Concentração: Física Aplicada \\ Opção: Física Computacional \\ Orientador: Prof. Dr. Luciano da Fontoura Costa \\ Colaborador: Prof. Dr. Marcelo Emilio Beletti
}

\section{Versão Original}

São Carlos

2015 
AUTORIZO A REPRODUÇÃO E DIVULGAÇÃO TOTAL OU PARCIAL DESTE TRABALHO, POR QUALQÜER MEIO CONVENCIONAL OU ELETRÔNICO PARA FINS DE ESTUDO E PESQUISA, DESDE QUE CITADA A FONTE.

Ficha catalográfica elaborada pelo Serviço de Biblioteca e Informação do IFSC, com os dados fornecidos pelo(a) autor(a)

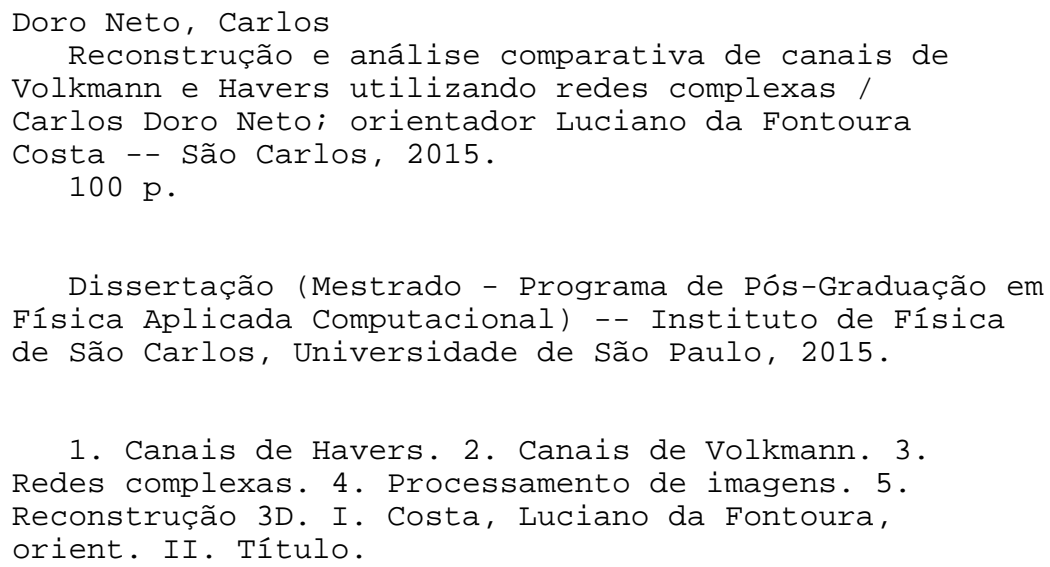




\section{FOLHA DE APROVAÇÃO}

Carlos Doro Neto

Dissertação apresentada ao Instituto de Física de São Carlos da Universidade de São Paulo para obtenção do título de Mestre em Ciências. Área de Concentração: Física Aplicada - Opção: Física Computacional.

Aprovado(a) em: 16/10/2015

Comissão Julgadora

Dr(a). Luciano da Fontoura Costa

Instituição: IFSC/USP

$\operatorname{Dr}(\mathrm{a})$. Siome Klein Goldenstein

Instituição: UNICAMP/Campinas

Dr(a). Solange Oliveira Rezende

Instituição: ICMC/USP 



\section{AGRADECIMENTOS}

Agradeço ao Prof. Luciano da Fontoura Costa, pela oportunidade concedida, por toda a paciencia, compreensão.

Ao Matheus Palhares Viana, por toda a ajuda no ínicio do projeto e por toda a colaboração, sem a qual este trabalho nunca seria realizado. Ao Prof. Marcelo Emilio Beletti, pelo trabalho de coletar todos o ossos e nos prover com material de pesquisa. À Cynthia Martins, que desenvolve o projeto junto comigo, pela ajuda na área biológica.

Aos Profs. Valtencir Zucolotto, Odemir Martinez Bruno, Marcelo Alves Barros, Gonzalo Travieso, Moacir Pereira Ponti Junior e Agma Juci Machado Traina, pelo tempo dedicado nos cursos e por todo o conhecimento transmitido.

Aos meus pais, Carlos e Nilva, pelo suporte e entendimento incondiconais. Às minhas irmãs Livia e Thais, pela convivência e amizade.

Aos amigos César "Bieber" Lodovico, Felipe "Fiapo" Soga, Gabriel "Fiapinho" Soga, Gustavo “Cabaré” Martins d'Oliveira, Hendrik Marques Soares, Marcos "Burguer" Gabriel Silveira, Arthur "Ligeiro" Piai, Natalia Martins, Vinicius “Kiwi” Katata. 
A todos os amigos que conheci no IFSC: Renato Fabri, Vilson Vieira, David Sbrissa, Débora Correa, Mauro Miazaki, César Comin, Thomas Peron, Krissia Zawadski, Renata Batista, Carol Silvério e Mônica Campiteli.

A Alexandre de Castro Maciel e Ricardo Fabbri cujos trabahlos ajudaram enormemente o desenvolvimento desse projeto.

Às comunidades de software livre e aberto, por todo o conhecimento e tecnologia repassados e que compõem esta contribuição. 
"Se soubéssemos o que estamos fazendo, isso não se chamaria pesquisa, não é?"

- Albert Einstein 



\section{RESUMO}

DORO NETO, C. Reconstrução e análise comparativa de canais de Volkmann e Havers utilizando redes complexas. 2015. 100 p. Dissertação (Mestrado) - Instituto de Física de São Carlos, Universidade de São Paulo, São Carlos, 2015.

Ossos, estruturas essenciais para a proteção de órgãos internos, estrutura corporal e suporte mecânico nos vertebrados, possuem uma complexa rede de canais (canais de Volkmann e Havers) responsáveis por nutrir as células do tecido. Entretanto a falta de estudos quantitativos leva a uma carência de medidas e parâmetros para a caracterização dessas estruturas. Utilizando computação gráfica, técnicas de processamento de imagens, e redes complexas descreveremos a obtenção, reconstrução, representação, e análise dessas redes de canais. Para isso, duas falanges distais, uma de um galo e uma de uma galinha, passaram por um processo de corte histológico, as lâminas resultantes foram fotografadas e as imagens tratadas até serem reconstruídas em 3D. Os volumes foram convertidos em redes complexas, o que permitiu o uso de métodos de análise consagrados pela literatura. As redes foram comparadas entre si e com a rede do trabalho desenvolvido por Matheus P. Viana et al. (1-3) usando análise de grau, posicionamento dos nós, detecção de comunidades, e ataques (em cascata e aleatórios). Três resultados se destacam: 1) as redes apresentam divisões predominantemente dicotômica dos canais; 2) as redes apresentam uma alta modularidade, indicando que áreas específicas desempenham funções específicas; e 3) as redes são particularmente resistentes a ataques em cascata.

Palavras-chave: Canais de Havers. Canais de Volkmann. Redes complexas. Processamento de imagens. Reconstrução 3D. 



\section{ABSTRACT}

DORO NETO, C. 3D reconstruction and comparative analysis of Volkmann and Havers canals with complex networks. 2015. 100p. Dissertação (Mestrado) - Instituto de Física de São Carlos, Universidade de São Paulo, São Carlos, 2015.

Bones are essential for the protection of internal organs, for body structure, and for mechanical support in vertebrates, and present a complex network of channels (Havers and Volkmann channels) required to nourish tissue cells. However, the lack of quantitative studies leads to scarce parameters and measures to characterize these structures. By using computational graphic, image processing, and complex networks we will describe the acquisitation, reconstruction, representation, and analysis of these channel networks. Two distal phalanges (one from a hen and one from a rooster) were submitted to hystological section processing; the resulting slices were photographed and the images were treated before 3D reconstruction. The volumes were converted into complex networks which allow us to use methods of analysis widely accepted in literature. Networks were compared with each other and with the network obtained in the study by Viana et al. (1-3) using degree analysis, node positioning, community detection, and random and systematic attacks. Three results stand out: (i) the networks show a predominantly dichotomic division of channels; (ii) the networks show high modularity, indicating that specific areas perform specific functions; and (iii) the networks are particularly resistant to cascate attacks.

Keywords: Havers canals. Volkmann canals. Complex networks. Image processing. 3D reconstruction. 



\section{LISTA DE FIGURAS}

Figura 2.1 - $\quad$ Desenho de corte transversal de um osso. Os canais de Havers e Volkmann são destacados no canto inferior direito. . . . . . . . 28

Figura 2.2 - $\quad$ Desenho linear mostrando o esqueleto de uma pata de galinha. No círculo está destacado a falange distal do dedo um. . . . . . 29

Figura 2.3 - $\quad$ Quatro fotografias da primeira lâmina de corte histológico do osso 1, cada uma representando um setor da lâmina original. . . 30

Figura 2.4 - $\quad$ Quatro fotografias da primeira lâmina de corte histológico do osso 2, cada uma representando um setor da lâmina original. . .

Figura 2.5 - $\quad$ Decomposição de uma imagem no espaço RGB. A imagem superior esquerda mostra a imagem original, as outras mostram os canais de cor vermelha (canto superior direito), de cor verde (canto inferior esquerdo) e de cor azul (canto inferior direito). 
Figura $2.6-$

Duas imagens de mesmo tamanho (físico) ilustram a diferença de resolução. A primeira imagem (à esquerda) possui resolução de $512 \times 512$, enquanto a segunda imagem (à direita) possui resolução de $64 \times 64$. Como a segunda imagem contém menos "pixels", cada um deles deve ser maior de forma que as duas imagens tenham o mesmo tamanho. . . . . . . . . 33

Figura 2.7 - Diferença entre uma imagem em escala de cinza (à esquerda) e uma imagem em preto e branco (à direita). . . . . . . . . . 34

Figura 2.8 - $\quad$ Quatro limiares distintos foram aplicados na imagem em escala de cinza da figura 2.7. Note como limiares cada vez menores tornam os círculos brancos. . . . . . . . . . . . 35

Figura 2.9 À esquerda imagem de entrada para o método de detecção de componentes e à direita representação de sua matriz. A saída do processo é exibida na figura $2.10 \ldots \ldots \ldots$. . . . . . . . 37

Figura 2.10 - $\quad$ À esquerda o resultado obtido a partir da imagem da figura $2.9 \mathrm{e}$ à direita sua representação gráfica. Note que cada um dos objetos da matriz possui um rótulo (cor) diferente. . . . . . . . 37

Figura 2.11 - Exemplo para o cálculo do fator de forma. Um quadrado de 4 "pixels" possui $\Gamma=\pi$ valor muito distante do previsto pela

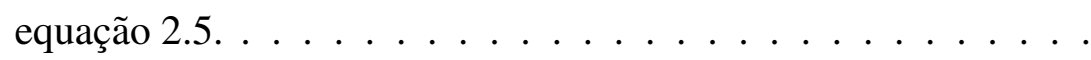

Figura 2.12 - Exemplo para o cálculo do fator de forma. Um quadrado de 16 "pixels" possui $\Gamma=\frac{4 \pi}{9}$, valor mais próximo do previsto pela equação 2.5. Note que $\Gamma$ será mais preciso quanto maior o upsampling. ...................... 40 
Figura 2.13 - No canto superior esquerdo, a imagem de entrada para a transformada distância, no canto superior direito, sua representação matricial. No canto inferior esquerdo, a matriz resultante da transformada distância e, no canto inferior direito, a representação gráfica da transformada. . . . . . . . . . . . . . . . . 4

Figura 2.14 - $\quad$ Imagem original à esquerda e imagem erodida à direita. O limiar para o processo de erosão é $t=10 \ldots \ldots \ldots \ldots$

Figura 2.15 - $\quad$ Imagem original à esquerda e imagem dilatada à direita. O limiar para o processo de dilatação é $t=10 \ldots \ldots$. . . . . . . 44

Figura 2.16 - $\quad$ Representação gráfica de um grafo. No caso, o grafo apresenta o exemplo de três cidades $A, B, C$ ligadas (ou não) por rodovias. 48

Figura 2.17 - $\quad$ Exemplo de um grafo direcionado e com pesos. . . . . . . . . 48

Figura 3.1 - $\quad$ Primeira lâmina do osso 2 remontada a partir das quatro imagens setorizadas vistas na figura $2.4 \ldots \ldots \ldots 5$

Figura 3.2 - Imagem após o tratamento de bordas. . . . . . . . . . 56

Figura 3.3 - $\quad$ Primeira lâmina do osso 1 (à esquerda), note como o canto superior direito é levemente mais claro que o restante da imagem. À direita, a binarização obtida pelo método de Otsu, note que apenas o método de Otsu não é capaz de diferenciar os canais da matriz óssea. . . . . . . . . . . . . . . . . 57

Figura 3.4 - $\quad$ Figura 3.2 após o processo de filtragem. O processo possuia janela de tamanho $l=50 \ldots \ldots \ldots \ldots$ 
Figura 3.5 -

Figura 3.6 -

Figura 3.7 -

Figura 3.8 -

Figura 3.9 -

Figura $3.10-$

Figura 3.11 -

Figura 3.12 -

Figura 3.13 -

Figura 3.14 -

Figura 3.15 -

Figura 3.16 -

Figura 3.18 -

Figura 3.19 -

Figura 3.20 -
Imagem após o processo de binarização. O limiar escolhido é o tom de fundo da imagem original. . . . . . . . . . . . . 59

Segmentação da matriz óssea. . . . . . . . . . . . . . . 60

Segmentação da rede de canais. . . . . . . . . . . . . . 61

Imagem após a remoção de ruídos. . . . . . . . . . . . . . 62

Primeira e segunda lâminas do osso 2 antes do processo de registro. 64 Primeira e segunda lâminas do osso 2 depois do processo de registro. ........................... 64

Reconstrução 3D para rede de canais do osso 1. . . . . . . . . 67

Reconstrução 3D para a maior componente da rede $2 \ldots$. . . . 68

Segmento do esqueleto (em azul) para a rede de canais (em amarelo) do osso $2 . \ldots \ldots \ldots$

Rede complexa para o osso $1 \ldots \ldots \ldots$. . . . . . . 70

Rede complexa para o osso $2 \ldots \ldots \ldots$. . . . . . . 71

Rede complexa do trabalho de Viana(1-3). . . . . . . . . 72

Histograma de valência para as três redes. No eixo das abscissas temos o valência dos vértice e no eixo das ordenadas temos a porcentagem de vértices com determinado valência. . . . . . . . 75

Distribuição ao longo do eixo radial para a rede Viana (a) e (b) e para o análogo aleatório (c) e (d). . . . . . . . . . . . 78

Distribuição ao longo do eixo radial para a rede 2 (a) e (b) e para o análogo aleatório (c) e (d). 
Figura 3.21 - Distribuição ao longo do eixo radial para a rede 1 (a) e (b) e para o análogo aleatório $(\mathrm{c})$ e $(\mathrm{d}) . \ldots \ldots$. . . . . . . . 80

Figura 3.22 - $\quad$ Distribuição para o ângulo azimutal para a rede Viana (a) e (b) e para o análogo aleatório (c) e (d). . . . . . . . . . . 81

Figura 3.23 - $\quad$ Distribuição para o ângulo azimutal para a rede 1 (a) e (b) e para o análogo aleatório $(\mathrm{c})$ e $(\mathrm{d}) . \ldots \ldots . \ldots . \ldots 82$

Figura 3.24 - Distribuição para o ângulo azimutal para a rede 2 (a) e (b) e para o análogo aleatório $(\mathrm{c})$ e $(\mathrm{d}) . \ldots \ldots \ldots$

Figura 3.25 - Distribuição ao longo do eixo longitudinal para a rede Viana (a) e (b) e para o análogo aleatório (c) e (d). . . . . . . . . . . 84

Figura 3.26 - Distribuição ao longo do eixo longitudinal para a rede 2 (a) e (b) e para o análogo aleatório $(\mathrm{c})$ e $(\mathrm{d}) \ldots \ldots \ldots$

Figura 3.27 - Distribuição ao longo do eixo longitudinal para a rede 1 (a) e (b) e para o análogo aleatório (c) e (d) . . . . . . . . . 86

Figura 3.28 - Durante o processo de ataques alguns vértices podem tornar-se isolados. O exemplo abaixo apresenta uma rede (a) que tem o vértice 4 removido deixando o vértice 6 sem vizinhos (b). Neste caso os vértices isolados são removidos do grafo (c) . . . . . . 88

Figura 3.29 - A remoção de vértices da rede pode acarretar em alguns vértices $\operatorname{com} k=2$. Como já discutido na seção 3.5 este caso não é válido. No exemplo abaixo o vértice 2 é removido da rede original (a) deixando o vértice 5 com apenas dois vizinhos (b). Note que para a rede de canais essa situação é análoga a uma ligação direta entre o vértice 1 e o vértice 4 (c). . . . . . . . . . . . 88 
Figura $3.31-\quad$ Falhas em arestas. . . . . . . . . . . . . . . . 90

Figura $3.32-\quad$ Ataques em cascata. . . . . . . . . . . . . 91

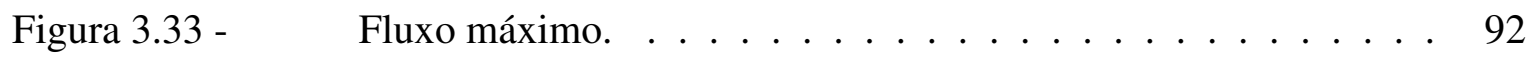




\section{LISTA DE TABELAS}

Tabela 3.17 - $\quad$ Resumo para o quantidade de vértices, quantidade de arestas e valência média de cada rede. . . . . . . . . . . . 73

Tabela 3.34 - $\quad$ Resumo para o quantidade de vértices, quantidade de arestas e valência média de cada rede. . . . . . . . . . . . . . 93 



\section{LISTA DE ABREVIAÇÕES}

$[u, v]$ Aresta que liga $u$ a $v$.

Г Circularidade.

$\rho, \theta, z$ Distância radial, coordenada angular e altura no sistemas de coordenadas cilíndrico.

$\varepsilon \quad$ Conjunto de arestas que pertencem ao grafo $G$.

$\vartheta \quad$ Conjunto de vértices que pertencem ao grafo $G$.

$|\varepsilon| \quad$ Quantidade de elementos no conjunto $\varepsilon$.

$|\vartheta| \quad$ Quantidade de elementos no conjunto $\vartheta$.

A Área de um objeto em uma imagem quando tratando de processamento de imagens ou matrix de adjacência quando tratando de redes complexas.

$c_{u} \quad$ Comunidade a qual o vértice $u$ pertence.

$e \quad$ Vértice final do fluxo.

f Taxa de de produção/consumo de material.

$G, H$ Grafos.

$i, j \quad$ Coordenadas horizontal e vertical de um "pixel” em uma matriz de imagem. 
$i, j, k$ Coordenadas do voxel dentro da matrix 3D.

im Matrix de imagem.

$k_{u} \quad$ Valência do vértice $u$.

$l \quad$ Tamanho da janela deslizante quando trtando de processamento de imagens ou comprimento de um caminho quando tratando de redes complexas.

$N \quad$ Número de canais em uma matrix de imagem.

$P \quad$ Perimetro do objeto em uma imagem.

Q Mudularidade.

$q \quad$ Quantização de um “pixel” em uma matrix.

$R, C \quad$ Dimensões da matrix de imagem.

$s \quad$ Vértice de começo do fluxo.

$t \quad$ Valor do limiar durante o processo de limiarização.

$u, v, w$ Vértices pertencentes a um grafo.

$X, Y, Z$ Dimensões da matrix 3D. 


\section{SUMÁRIO}

1 Introdução $\quad 25$

2 Fundamentos 27

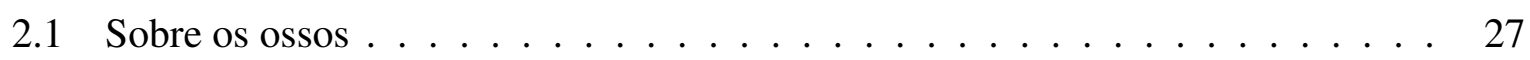

2.2 Processamento de imagens . . . . . . . . . . . . . . . 32

2.2 .1 Limiarização . . . . . . . . . . . . . . . . . . . 34

2.2.2 Detecção de componentes conexas . . . . . . . . . . . . . . . . 36

2.2 .3 Fator de forma . . . . . . . . . . . . . . . 36

2.2.4 Implementação de fator de forma . . . . . . . . . . . . . . . . . . . . 39

2.2.5 Transformada distância . . . . . . . . . . . . . . . . . . . 40

2.2.6 Dilatação e erosão, abertura e fechamento . . . . . . . . . . . . . . 42

2.2 .7 Volumes . . . . . . . . . . . . . . . . . . . . . . 44

2.3 Redes complexas . . . . . . . . . . . . . . . . . 45

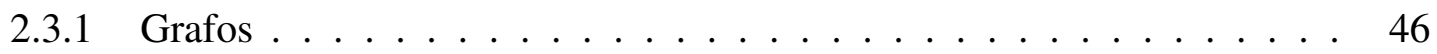

2.3.2 Valência . . . . . . . . . . . . . . . . . . . 49 


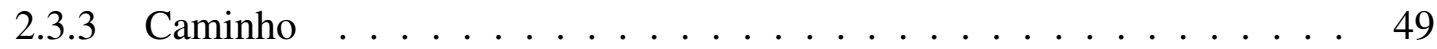

2.3 .4 Fluxo máximo . . . . . . . . . . . . . . . . . . . . . . . . . . 49

2.3.5 Ataques e falhas . . . . . . . . . . . . . . . . 50

2.3.6 Comunidades . . . . . . . . . . . . . . . . . 51

2.3.7 Redes aleatórias . . . . . . . . . . . . . . . . 52

3 Desenvolvimentos e resultados 53

3.1 Tratamento de bordas . . . . . . . . . . . . . . . . . . 54

3.2 Método da janela deslizante . . . . . . . . . . . . . . . . . . 56

3.3 Segmentação e remoção de ruído . . . . . . . . . . . . . . . . . . . . . 58

3.4 Registro . . . . . . . . . . . . . . . . . . . 63

3.5 Reconstrução 3D . . . . . . . . . . . . . . . . . . . . . . . 65

3.6 Redes complexas . . . . . . . . . . . . . . . . . . . . 73

3.7 Análise de valência . . . . . . . . . . . . . . . . . . . . . . . 74

3.8 Posicionamento dos vértices $\ldots \ldots \ldots \ldots \ldots$

3.9 Ataques . . . . . . . . . . . . . . . . . . . . 87

3.10 Comunidades . . . . . . . . . . . . . . . . . . 93

4 Conclusões $\quad 95$

$\begin{array}{ll}\text { REFERÊNCIAS } & 97\end{array}$ 


\section{Capítulo 1}

\section{Introdução}

Ossos são responsáveis pela proteção de órgãos internos, estrutura corporal, suporte mecânico, capacidade de locomoção e armazenamento de minerais (especialmente cálcio), dessa forma o estudo sobre sua estrutura e aspectos geométricos, sua formação e funcionamento, e seu comportamento sob diferentes circuntâncias se torna importante (4-6), especificamente, para ser capaz de determinar medidas e quantificar parâmetros se torna essencial para o desenvolvimento de aplicações em medicina e bioengenharia. Uma caracteristica dos ossos é possuir uma rede de canais $(7,8)$ responsáveis por nutrir as células do tecido (denominados canais de Volkmann e canais Havers).

O trabalho de Leonard Euler sobre as sete pontes de Königsberg, publicado em 1735, é considerado a origem da teoria de grafos. Hoje, duzentos e oitenta anos depois, o conceito de grafos é invocado sempre que temos um sistema de objetos interligados, em especial a área de redes complexas é utilizada para descrever processos físicos $(9,10)$ e biológicos $(11-13)$, tornando softwares para solução de problemas relacionados à redes complexas de grande interesse. Apesar do potencial de redes complexas para analisar os canais de Havers e Volkmann, poucos estudos $(1,2)$ se propõem a aplicar a teoria de grafos para essa rede canais. 
Neste texto descreveremos a obtenção de redes de Volkmann e Havers, sua reconstrução computadorizada em 3D, sua representação em redes complexas, e a análise das mesmas. Os objetivos deste trabalho podem ser resumidos nos seguintes tópicos: criar um procedimento automatizado para a reconstrução computadorizada tridimensional da rede de canais buscando aprimorar a qualidade da reconstrução, e diminuir o tempo de trabalho e representar as estruturas em redes complexas, possibilitando a comparação entre diferentes organismos.

A seguir se apresenta a organização deste documento. O capítulo 2 apresenta os conceitos necessários para o entendimento do restante do documento e é dividido em três partes, a seção 2.1 descreve a obtenção e as características dos ossos utilizados neste estudo, a seção 2.2 apresenta os métodos relacionados ao processamento das imagens, assim como a base teórica dos mesmos, na seção 2.3 introduzimos redes complexas e os algoritmos utilizados. O capítulo 3 apresenta o processamento das imagens até sua reconstrução 3D e o resultados das análise das redes complexas. No capítulo 4 são apresentadas apresentadas as conclusões das análises. 


\section{Capítulo 2}

\section{Fundamentos}

Este capítulo apresenta os fundamentos e conceitos utilizados durante o processamento das imagens e na análise das redes complexas, em especial, apresenta as convenções e nomenclaturas utilizadas ao decorrer do texto.

\subsection{Sobre os ossos}

Antes de aprofundar nos métodos e algoritmos utilizados, é indispensável analisar nosso objeto de estudo, bem como seu método de aquisição. Canais de Havers (7), ou canais haversianos, são uma série de canais compostos de lamela, localizados no osso cortical e dispostos paralelamente ao eixo longitudinal do osso, por onde correm (um ou dois) vasos sanguíneos e céulas nervosas (vide figura 2.1). Canais de Volkmann conectam os canais de Havers entre si e com o periósteo, e são geralmente obtusos aos canais de Havers (dispostos transversalmente ao eixo longitudianl do osso). 


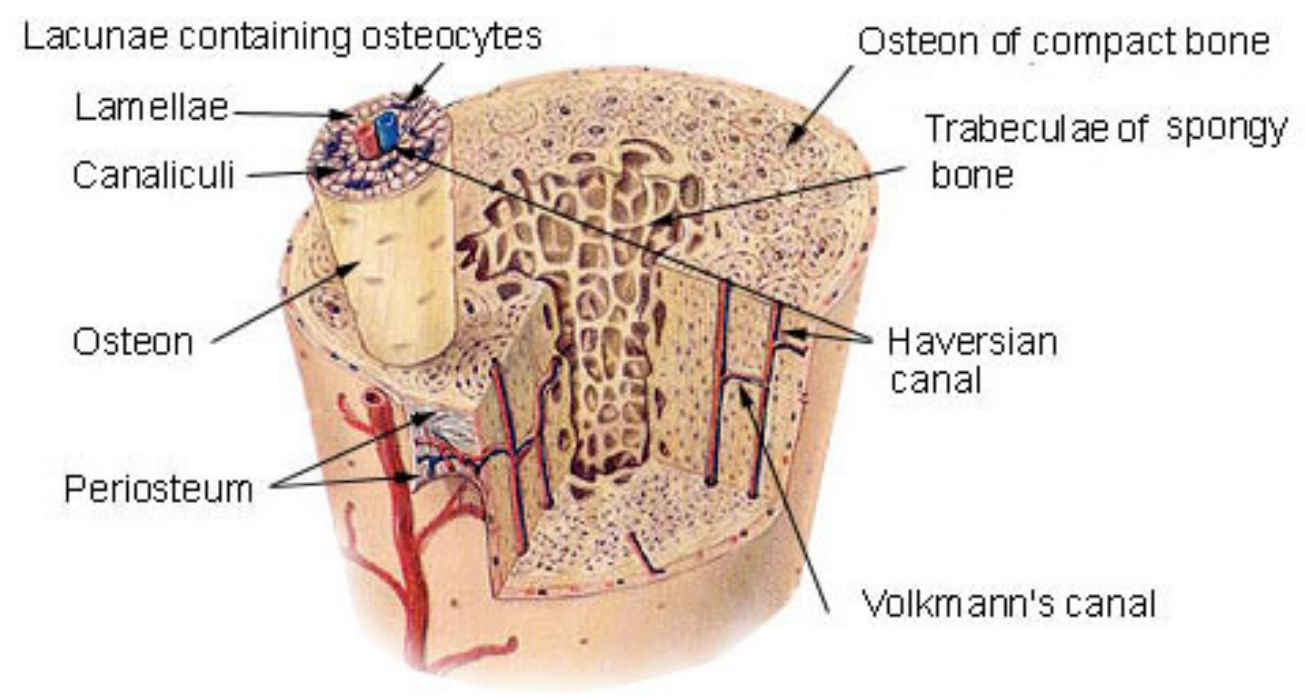

Figura 2.1 - Desenho de corte transversal de um osso. Os canais de Havers e Volkmann são destacados no canto inferior direito.

Fonte: NATIONAL ... (14)

Nosso colaborador, Prof. Dr. Marcelo Emílio Beletti $(15,16)$, nos forneceu as imagens de duas falanges distais (figura 2.2) do dedo um da pata direita, uma proveniente de um galo e a outra de uma galinha. Os espécimes não possuíam raça definida e foram sacrificados com aproximadamente nove meses de idade. Cada osso passou por um processo de corte histológico no qual o material biológico foi cortado em várias fatias (ou lâminas) transversais com um espaçamento aproximado de sete micrômetros. As lâminas são suficientemente finas para serem transparente e foram fotografadas contra um fundo iluminado em um microscópio.

Devido a limitações do equipamento, mais de uma foto foi usada por fatia, assim cada foto não representa a lâmina inteira mas apenas parte dela. Isso implica que posteriormente elas deverão ser compostas para obtermos nossa imagem completa (vide capítulo 3), note que esse processo não garante o alinhamento nem entre as várias fotografias da mesma lâmina, nem entre 


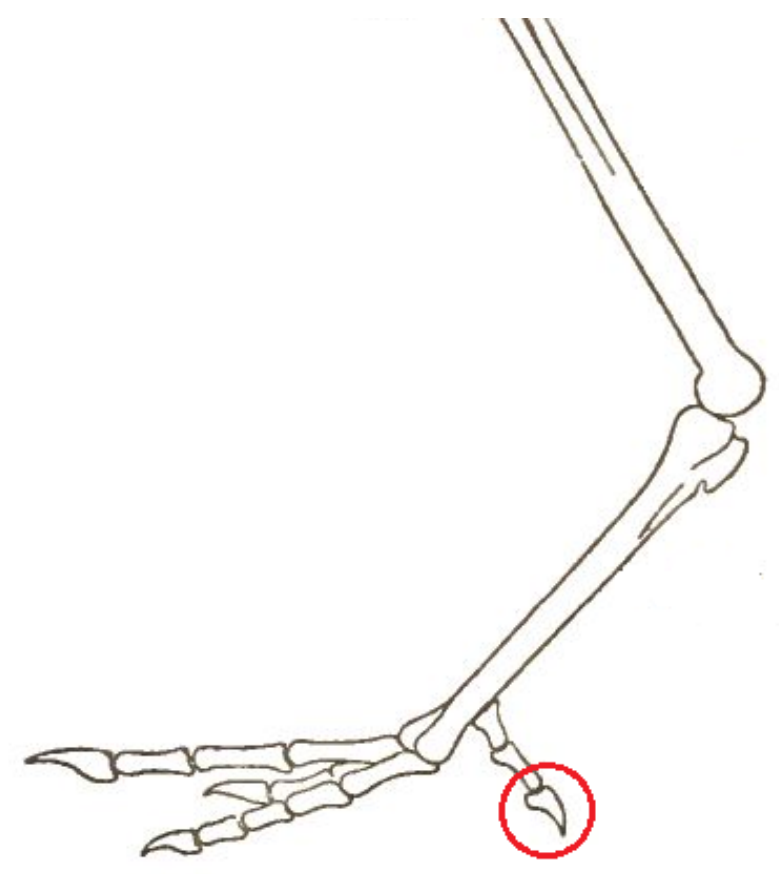

Figura 2.2 - Desenho linear mostrando o esqueleto de uma pata de galinha. No círculo está destacado a falange distal do dedo um.

Fonte: $B R A D L E Y(17)$

as várias lâminas entre elas, o que implica que elas também devem ser alinhadas posteriormente (seção 3.4). As figuras 2.3 e 2.4 mostram, respectivamente, as quatro fotografias obtidas para a primeira lâmina do osso 1 e para a primeira lâmina do osso 2 .

É importante destacar que a qualidade da reconstrução é diretamente ligada a qualidade do processo de corte histológico, logo as lâminas comprometidas foram descartadas. Acreditamos que isso gere pouca influência sobre a fidelidade da reconstrução dada a quantidade total de lâminas (da ordem de 650) em frente a quantidade comprometida (menos que 30). 

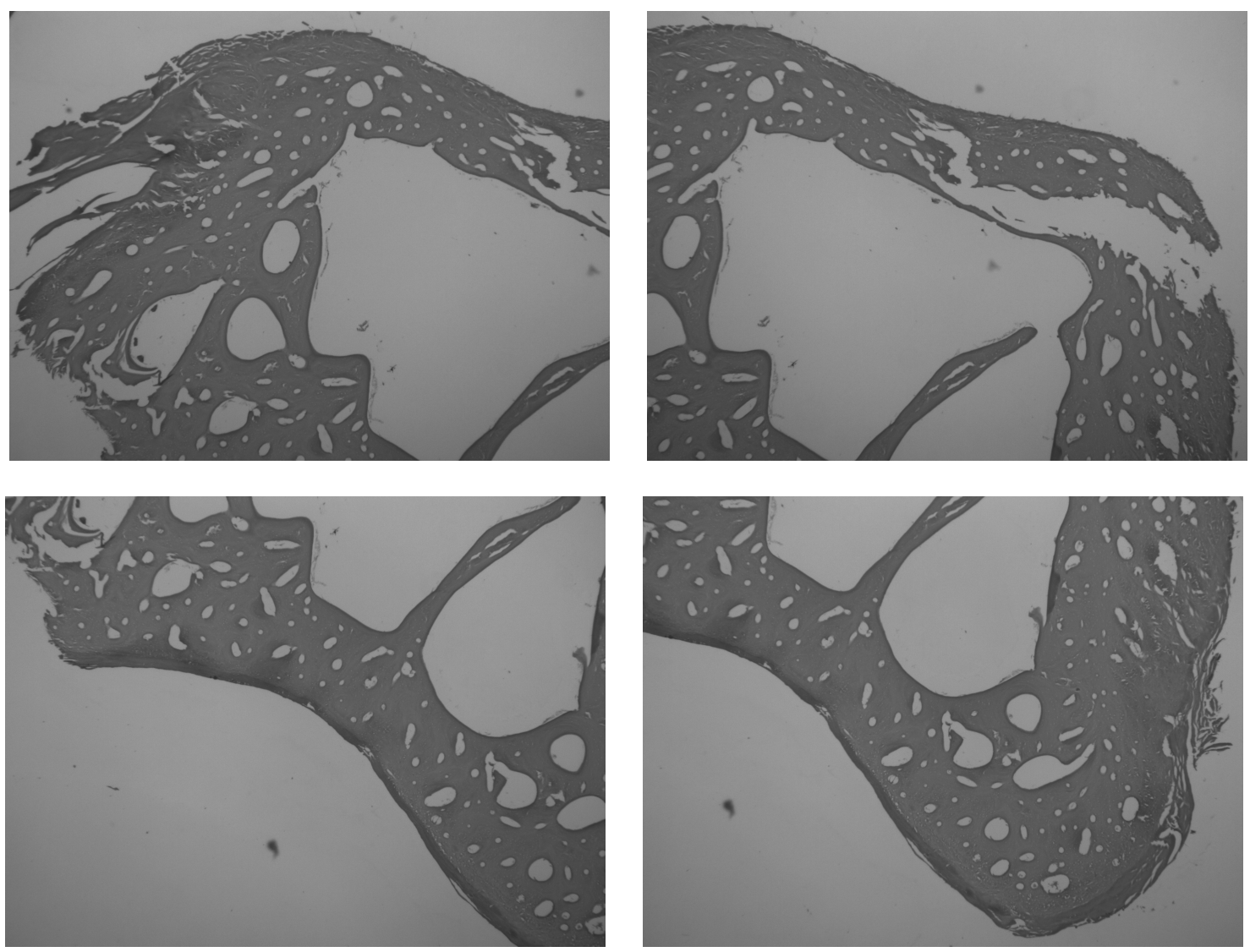

Figura 2.3 - Quatro fotografias da primeira lâmina de corte histológico do osso 1, cada uma representando um setor da lâmina original.

Fonte: Elaborada pelo autor. 

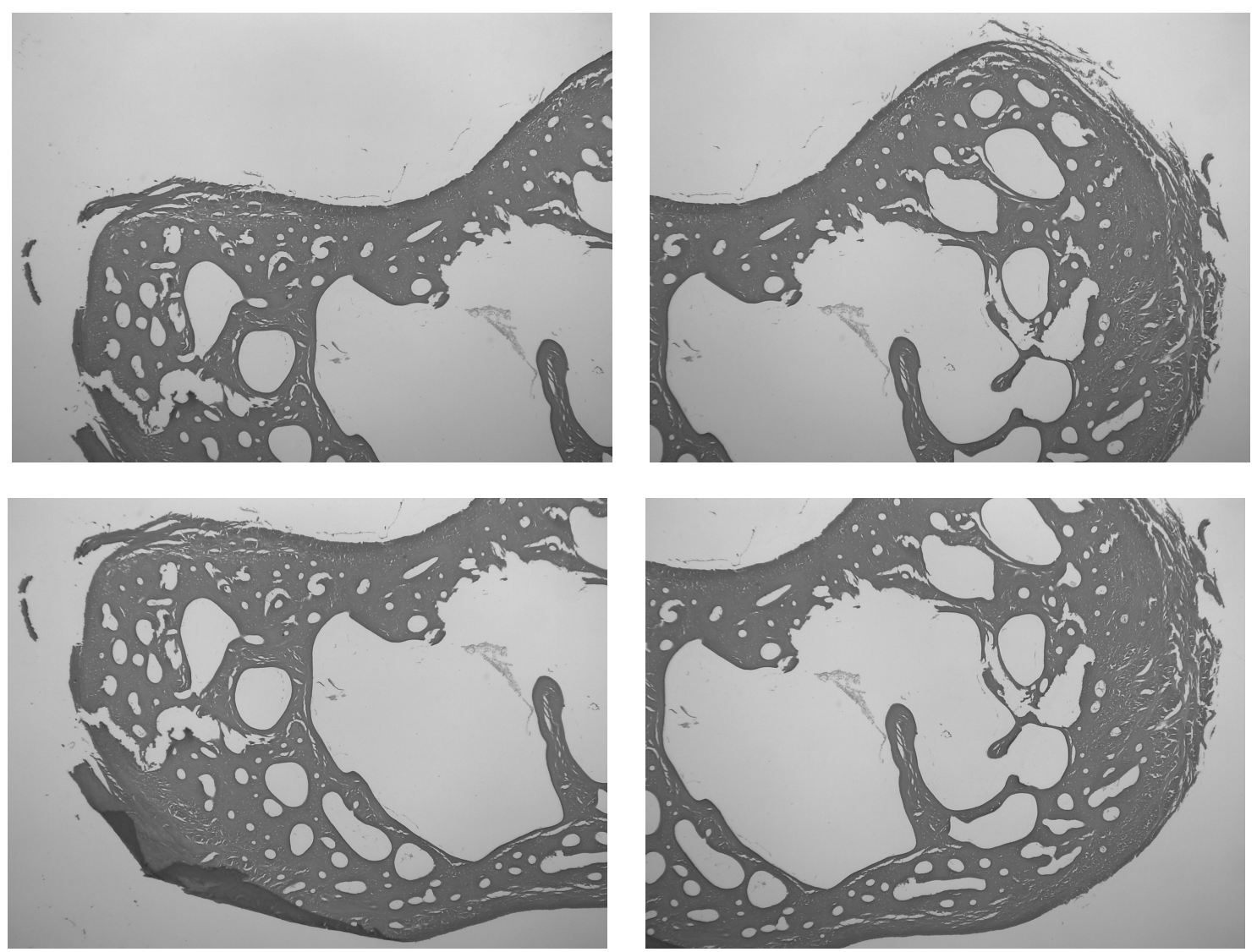

Figura 2.4 - Quatro fotografias da primeira lâmina de corte histológico do osso 2, cada uma representando um setor da lâmina original.

Fonte: Elaborada pelo autor. 


\subsection{Processamento de imagens}

Como primeiro tópico devemos entender como imagens são representadas em um computador e as operações que realizaremos sobre elas. Imagens são representadas por um conjunto de $N$ matrizes (geralmente uma, três ou quatro), todas com mesmo tamanho $R$ por $C$, contendo um total de $N \times R \times C$ elementos. Cada uma das $N$ matrizes da imagem é denominada de um canal e guarda a informação de uma das cores do espaço de cor.
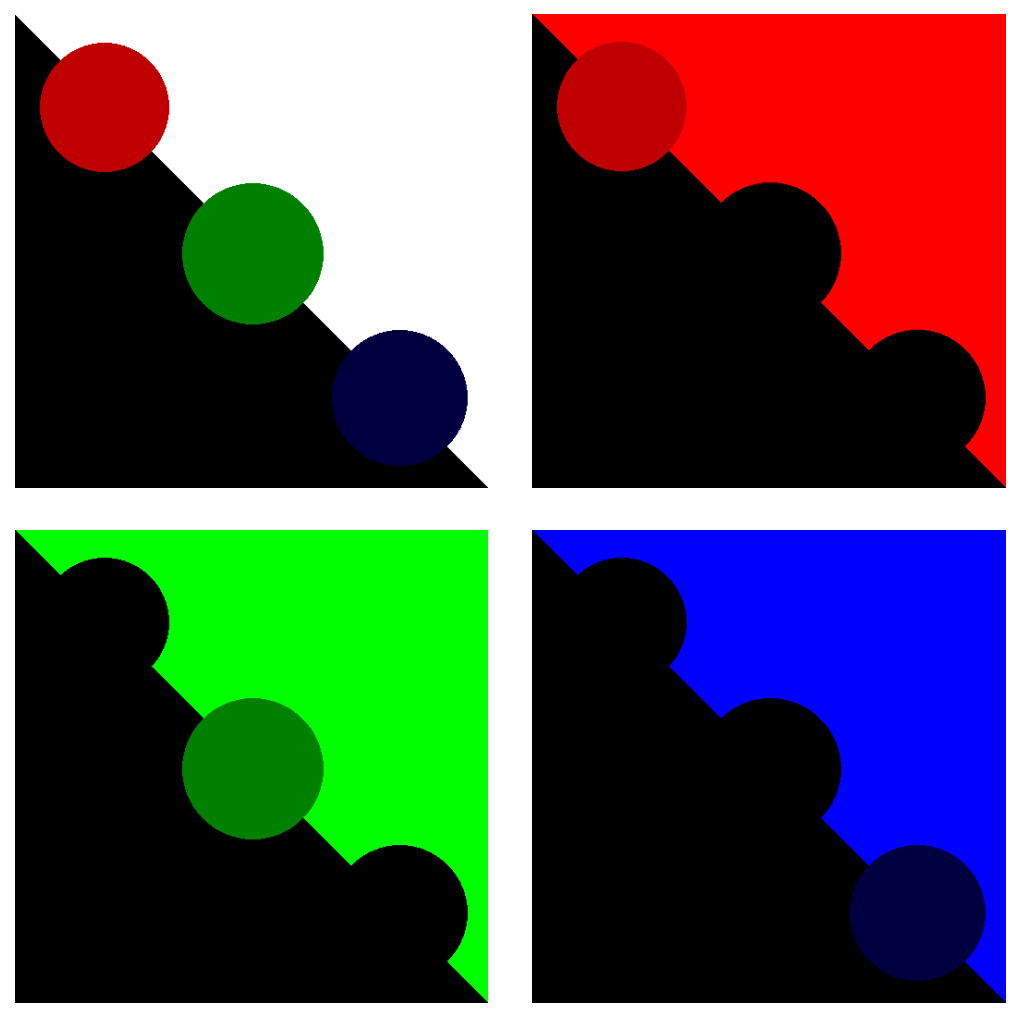

Figura 2.5 - Decomposição de uma imagem no espaço RGB. A imagem superior esquerda mostra a imagem original, as outras mostram os canais de cor vermelha (canto superior direito), de cor verde (canto inferior esquerdo) e de cor azul (canto inferior direito).

Fonte: Elaborada pelo autor.

Embora existam vários espaços de cor (e.g.: CMY, CMYK, Lab, XYZ, YUV, HSV, HSL, YCbCr), o espaço de cor normalmente usado para imagens é o RGB (vide fig. 2.5), que decompõe a imagem em três canais; um para a cor vermelha $(R)$, um para a cor verde $(G)$ e um 
para a cor azul (B). Note que alguns padrões podem guardar informações de transparência em um dos canais (e.g.: RGBA) e que imagens com apenas um canal são denominadas imagens em escala de cinza (não confundir com imagens em preto e branco).

O tamanho de cada uma das $\mathrm{N}$ matrizes é denominado de amostragem ou resolução da imagem (não confundir com tamanho da imagem, vide figura 2.6), logo uma matriz com 768 linhas $(R=768)$ e 1024 colunas $(C=1024)$ possui uma resolução de $1024 \times 768$ e contém 786.432 elementos, cada um contendo uma coordena $i, j$ dentro da matriz.

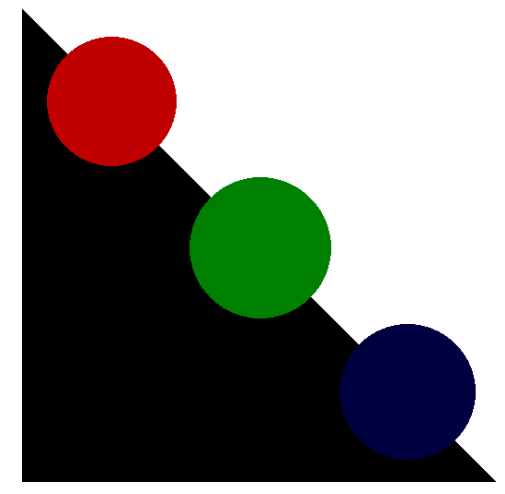

(a)

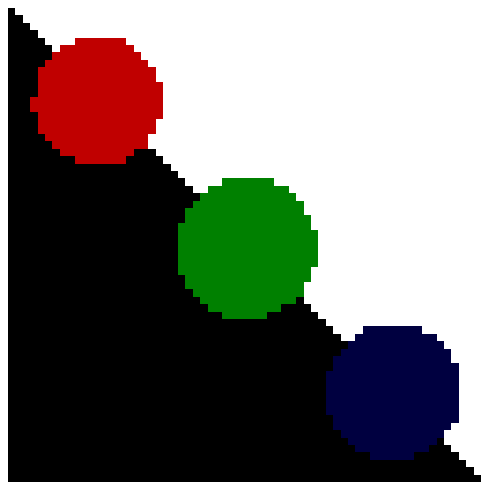

(b)

Figura 2.6 - Duas imagens de mesmo tamanho (físico) ilustram a diferença de resolução. A primeira imagem (à esquerda) possui resolução de $512 \times 512$, enquanto a segunda imagem (à direita) possui resolução de $64 \times 64$. Como a segunda imagem contém menos "pixels", cada um deles deve ser maior de forma que as duas imagens tenham o mesmo tamanho.

Fonte: Elaborada pelo autor.

Os elementos das matrizes são denominados de "pixels" (ou píxeis) e guardam informação sobre a intensidade da luz naquela posição. "Pixels" podem conter mais ou menos informação dependendo da quantidade de memória reservada a eles, essa quantidade é denomina de quantização (representada pela letra $q$ e medida em "bits") tendo dois casos de destaque $q=1$ e $q=8$. Todas as imagens utilizadas durante o projeto estão em um de dois formatos: ou escala de cinza, ou preto e branco (também conhecida como imagem binária). Essa observação, embora técnica, é de importância crítica para os fins deste documento, uma imagem binária se restringe a apenas dois valores (zero e um, daí seu nome), já a imagem em escala de cinza pode conter quaisquer 
dos 256 valores dentro do intervalo dinâmico (vide figura 2.7).

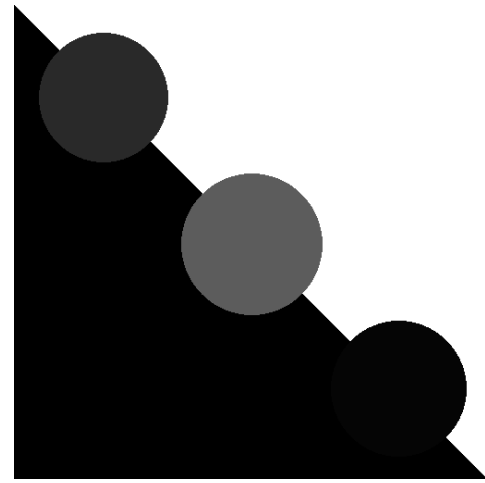

(a)

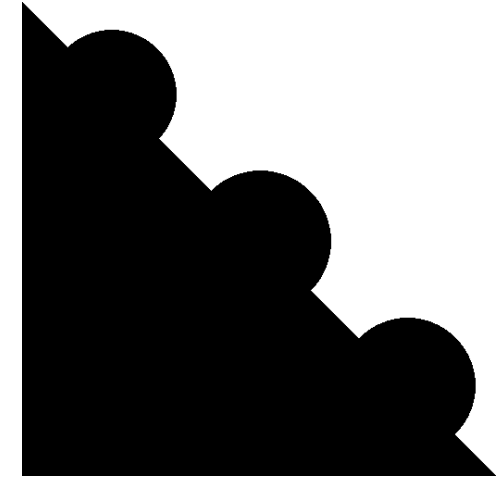

(b)

Figura 2.7 - Diferença entre uma imagem em escala de cinza (à esquerda) e uma imagem em preto e branco (à direita).

Fonte: Elaborada pelo autor.

\subsubsection{Limiarização}

A operação de limiarização (ou binarização) consiste em uma das técnicas para converter imagens em escala de cinza em imagens em preto e branco. Um valor limiar $t$ é definido tal que qualquer "pixel" com valor igual ou acima do limiar se transformará em branco (um) e que qualquer "pixel" com valor abaixo do limiar se transformará em preto (zero), matematicamente:

$$
\operatorname{im}(i, j)= \begin{cases}1, & \text { se } i m(i, j) \geq t \\ 0, & \text { se } i m(i, j)<t\end{cases}
$$

A fim de exemplo, quatro limiares diferentes foram aplicados na imagem 2.7a, o resultado é exibido na figura 2.8 .

Por último, duas notas: primeiro ao método de Otsu (18) que pode determinar automaticamente um limiar de separação ótimo para uma imagem em escala de cinza, segundo que adotamos 


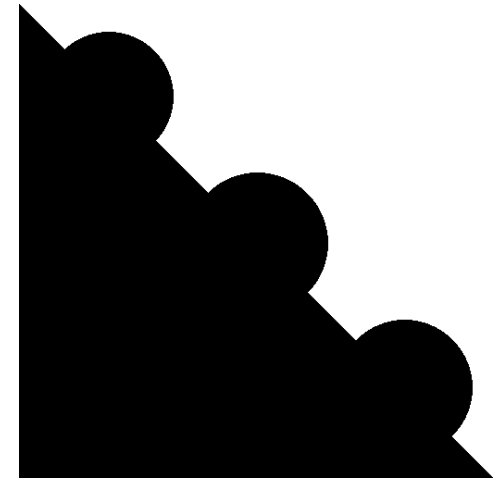

(a) $t=127$

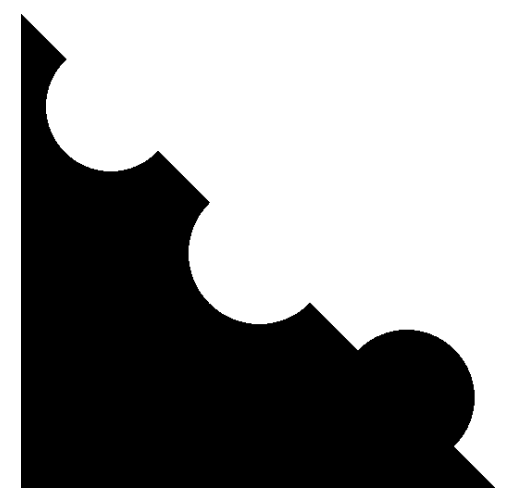

(c) $t=41$

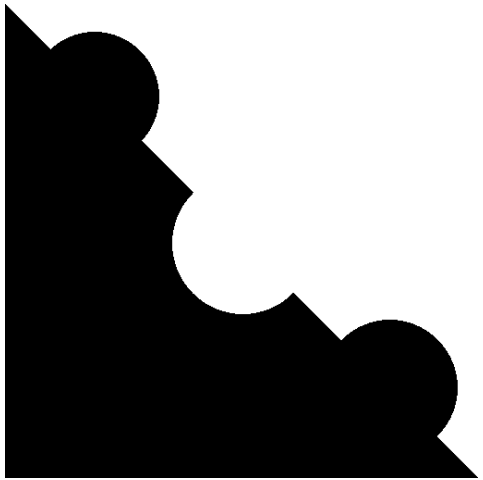

(b) $t=92$

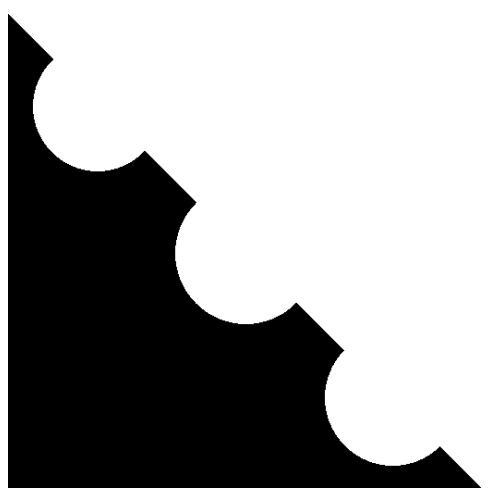

(d) $t=5$

Figura 2.8 - Quatro limiares distintos foram aplicados na imagem em escala de cinza da figura 2.7. Note como limiares cada vez menores tornam os círculos brancos.

Fonte: Elaborada pelo autor.

a convenção de objetos brancos sobre fundo preto (em contraste com o intuitivo objeto preto sobre fundo branco usado em escrita com papel e lápis). 


\subsubsection{Detecção de componentes conexas}

Esta seção apresenta o conceito da detecção de componentes conexas. A técnica segmenta os diferentes objetos (estruturas em branco) de uma imagem binária pelo fato de eles serem (ou não) conectados entre si, separando os diferentes objetos da imagem por rótulos $(19,20)$. Pasa isso aplicamos detecção de contorno nos objetos da imagem e em seguida preenchemos cada contorno com um tom diferente.

Usemos a figura 2.9a como exemplo, a imagem apresenta três objetos: um quadrado (canto inferior esquerdo), um triangulo (canto superior esquerdo) e uma "escada" (canto superior direito), enquanto a imagem à direita (figura 2.9b) mostra a representação matricial dessa imagem. Neste exemplo podemos claramente distinguir os objetos pois eles não se conectam entre si. O método atribui um valor distinto para cada um dos objetos sendo que o fundo sempre recebe o valor zero. A saída do método (figura 2.10a) é uma matriz onde cada objeto recebe um valor; nesse caso o triangulo recebeu valor 1, a "escada" valor 2 , e o retângulo 3.

\subsubsection{Fator de forma}

Fator de forma (21) são grandezas adimensionais utilizadas para descrever numericamente algum formato, nesta pesquisa usaremos a circularidade. Para uma figura de área $A$ e perímetro $P$, a circularidade (aqui representada pela letra grega $\Gamma$ ) pode ser definida como:

$$
\Gamma=\frac{4 \pi A}{P^{2}}
$$

De acordo com essa definição círculos possuem $\Gamma=1$, e toda outra forma um valor $\Gamma<1$ (de fato quanto mais ângulos e mais agudos os ângulos, menor o fator de forma). Outra definição, igualmente válida, usa o perímetro dividido pela raiz quadrada da área, entretanto esta definição 


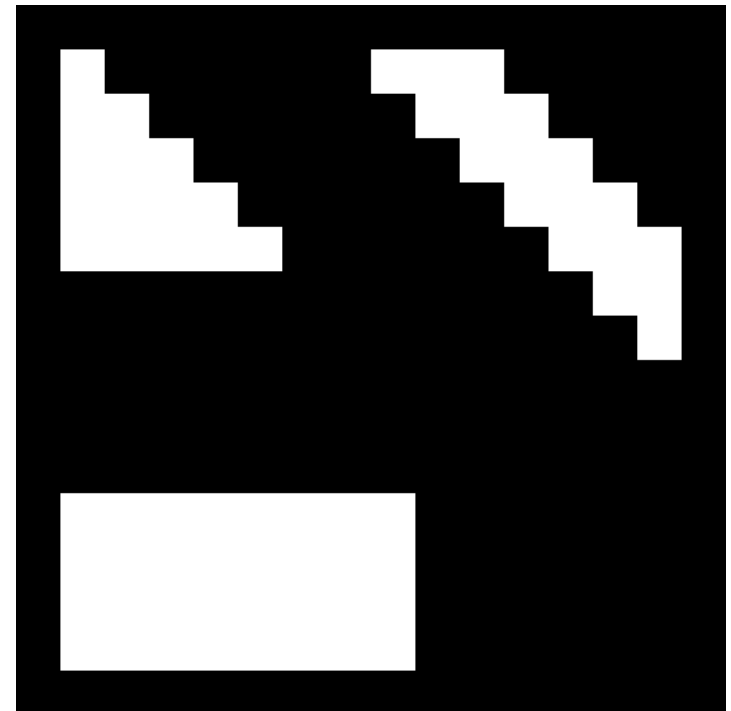

(a)

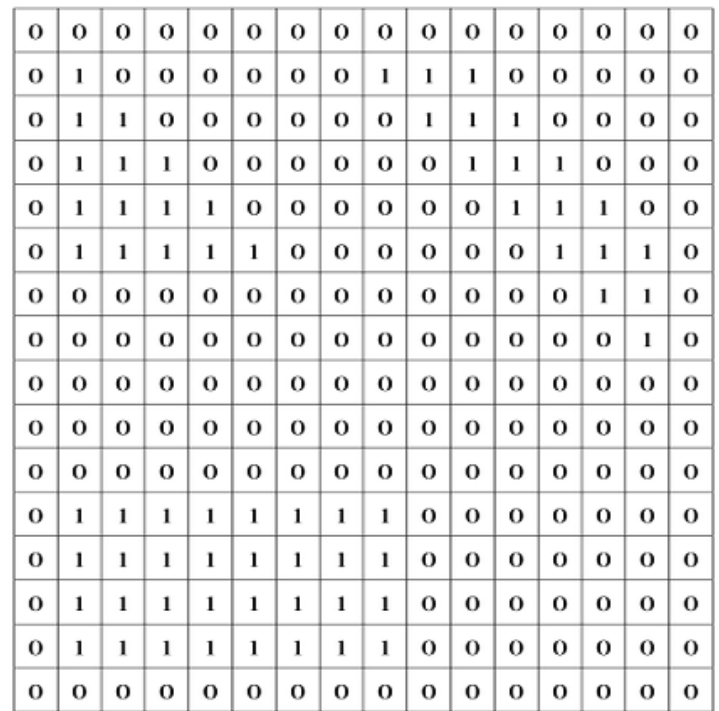

(b)

Figura 2.9 - À esquerda imagem de entrada para o método de detecção de componentes e à direita representação de sua matriz. A saída do processo é exibida na figura 2.10.

Fonte: Elaborada pelo autor.

\begin{tabular}{|l|l|l|l|l|l|l|l|l|l|l|l|l|l|l|l|}
\hline o & 0 & 0 & 0 & 0 & 0 & 0 & 0 & 0 & 0 & 0 & 0 & 0 & 0 & 0 & 0 \\
\hline o & 1 & 0 & 0 & 0 & 0 & 0 & 0 & 2 & 2 & 2 & 0 & 0 & 0 & 0 & 0 \\
\hline o & 1 & 1 & 0 & 0 & 0 & 0 & 0 & 0 & 2 & 2 & 2 & 0 & 0 & 0 & 0 \\
\hline 0 & 1 & 1 & 1 & 0 & 0 & 0 & 0 & 0 & 0 & 2 & 2 & 2 & 0 & 0 & 0 \\
\hline o & 1 & 1 & 1 & 1 & 0 & 0 & 0 & 0 & 0 & 0 & 2 & 2 & 2 & 0 & 0 \\
\hline o & 1 & 1 & 1 & 1 & 1 & 0 & 0 & 0 & 0 & 0 & 0 & 2 & 2 & 2 & 0 \\
\hline o & 0 & 0 & 0 & 0 & 0 & 0 & 0 & 0 & 0 & 0 & 0 & 0 & 2 & 2 & 0 \\
\hline o & 0 & 0 & 0 & 0 & 0 & 0 & 0 & 0 & 0 & 0 & 0 & 0 & 0 & 2 & 0 \\
\hline 0 & 0 & 0 & 0 & 0 & 0 & 0 & 0 & 0 & 0 & 0 & 0 & 0 & 0 & 0 & 0 \\
\hline 0 & 0 & 0 & 0 & 0 & 0 & 0 & 0 & 0 & 0 & 0 & 0 & 0 & 0 & 0 & 0 \\
\hline 0 & 0 & 0 & 0 & 0 & 0 & 0 & 0 & 0 & 0 & 0 & 0 & 0 & 0 & 0 & 0 \\
\hline 0 & 3 & 3 & 3 & 3 & 3 & 3 & 3 & 3 & 0 & 0 & 0 & 0 & 0 & 0 & 0 \\
\hline 0 & 3 & 3 & 3 & 3 & 3 & 3 & 3 & 3 & 0 & 0 & 0 & 0 & 0 & 0 & 0 \\
\hline 0 & 3 & 3 & 3 & 3 & 3 & 3 & 3 & 3 & 0 & 0 & 0 & 0 & 0 & 0 & 0 \\
\hline 0 & 3 & 3 & 3 & 3 & 3 & 3 & 3 & 3 & 0 & 0 & 0 & 0 & 0 & 0 & 0 \\
\hline 0 & 0 & 0 & 0 & 0 & 0 & 0 & 0 & 0 & 0 & 0 & 0 & 0 & 0 & 0 & 0 \\
\hline
\end{tabular}

(a)

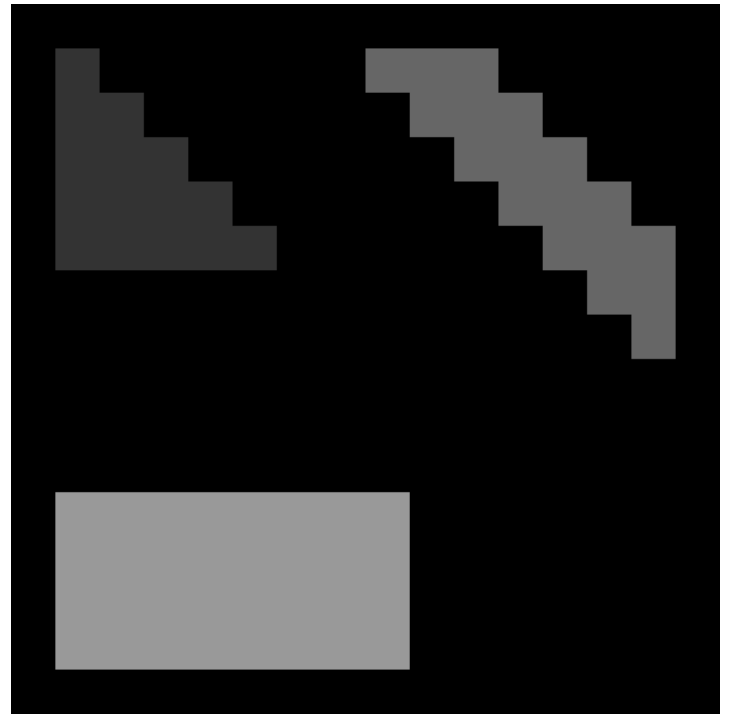

(b)

Figura 2.10 - À esquerda o resultado obtido a partir da imagem da figura 2.9 e à direita sua representação gráfica. Note que cada um dos objetos da matriz possui um rótulo (cor) diferente.

Fonte: Elaborada pelo autor. 
está compreendida no intervalo $1 \leq \Gamma \leq \infty$ e uma vez que grandezas infinitas não são facilmente representáveis em computadores, ficaremos com a definição dada pela equação 2.2.

Independente da definição utilizada temos a mesma a interpretação: a de quão capaz a borda é de preencher o espaço delimitado pela área. Embora essa interpretação seja semelhante à interpretação utilizada para dimensão fractal (22) as duas grandezas não guardam relação entre si. Para um melhor entendimento do conceito e de sua interpretação, apresentaremos um exemplo. Imaginemos um quadrado de lado $L$, a área $A$ e o perímetro $P$ serão dados, respectivamente, por:

$$
A=L^{2}
$$

$\mathrm{e}$

$$
P=4 L
$$

E pela definição de fator de forma (equação 2.2):

$$
\Gamma=\frac{4 \pi L^{2}}{(4 L)^{2}}=\frac{\pi}{4} \approx 0.79
$$

Igualmente, poderíamos calcular a circularidade para um triangulo equilátero $\left(\Gamma=\frac{\pi}{3 \sqrt{3}} \approx 0.60\right)$, para a letra a $(\Gamma \approx 0.11)$, ou qualquer outro formato. Note que $\Gamma$ é constante para uma forma específica e que nenhuma suposição sobre a orientação, o tamanho ou a posição das figuras foi feita e portanto temos invariância a rotação, escala e translação. 


\subsubsection{Implementação de fator de forma}

Para calcular os valores do perímetro e da área, usaremos respectivamente, a quantidade de "pixels" que formam o contorno do objeto e a quantidade de "pixels" total do objeto, entretanto essa abordagem pode levar a valores errados do perímetro e, consequentemente do fator de forma, principalmente para objetos pequenos. Por exemplo: na figura 2.11 um quadrado formado por quatro "pixels" (lado igual a dois) teria de acordo com nosso algoritmo $P=4 \mathrm{e}$ $A=4$ resultando em $\Gamma=\pi$ (vide eq. 2.5 ), valor muito distante do esperado $\Gamma=\pi / 4$ (vide sec. 2.2.3).

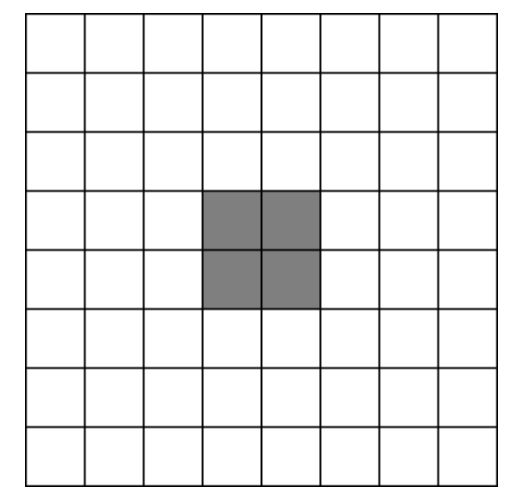

Figura 2.11 - Exemplo para o cálculo do fator de forma. Um quadrado de 4 "pixels" possui $\Gamma=\pi$ valor muito distante do previsto pela equação 2.5 .

Fonte: Elaborada pelo autor.

Sobre esse ponto, há duas considerações: Primeiramente, isso se dá pois em um computador o comprimento do contorno de um objeto não é contínuo, e portanto calcular o perímetro como a quantidade de "pixels" do contorno é uma aproximação (aproximação que é tanto mais válida quanto maior o objeto). Em segundo lugar, ressaltar que o valor $\Gamma=\pi$ é teoricamente proibido, uma vez que $0 \leq \Gamma \leq 1$, e que esse comportamento é característico de baixas resoluções.

Para evitar esse problema aplicaremos um "upsampling” em todos os objetos para uma mesma resolução e então calcularemos o valor do fator de forma, garantindo o regime onde a aproximação 
é válida. A figura 2.12 mostra o mesmo quadrado da figura 2.11 representado em uma resolução maior. Agora o quadrado é formado por dezesseis "pixels" (lado igual a quatro) e teria de acordo com nosso algoritmo $P=12$ e $A=16$ resultando em $\Gamma=\frac{4 \pi}{9} \approx 1.40$, valor ainda distante de $\Gamma=\pi / 4$ mas que será tanto mais acurado quanto maior o "upsampling".

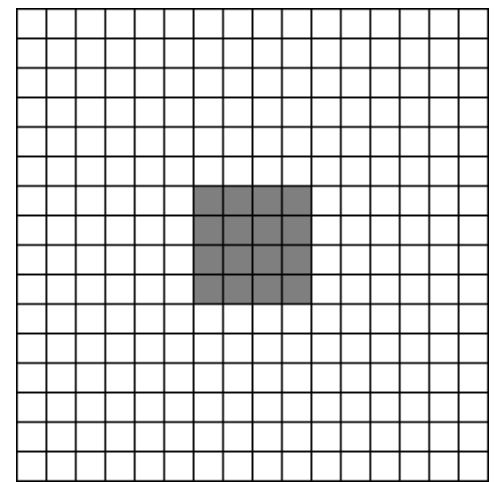

Figura 2.12 - Exemplo para o cálculo do fator de forma. Um quadrado de 16 "pixels" possui $\Gamma=\frac{4 \pi}{9}$, valor mais próximo do previsto pela equação 2.5. Note que $\Gamma$ será mais preciso quanto maior o upsampling.

Fonte: Elaborada pelo autor.

\subsubsection{Transformada distância}

Uma ferramenta necessária para as próximas seções (2.2.6 e 3.5) é a transformada distância (23), para fins didáticos apresentaremos sua versão bidimensional, entretanto a generalização para três (ou mais) dimensões é intuitiva. Para uma imagem binária (lembrando que assumimos "pixels" de valor nulo como fundo e "pixels" de valor unitário como objeto) cada "pixel” não nulo tem seu valor convertido para a menor distância entre ele e um "pixel" de valor zero, ou seja, os "pixels" do objeto passam a guardar a menor distância entre eles até a borda do objeto, dessa forma "pixels" perto das bordas recebem valores baixos enquanto que "pixels" no centro do objeto recebem valores altos.

A figura 2.13a mostra uma imagem binária na qual será aplicada a transformada distância e na 
figura $2.13 \mathrm{c}$ temos a matriz resultante do processo. Note que nesse exemplo os vizinhos na diagonal estão a uma distância 1 do "pixel" de referência (vizinhança de 8 "pixels"), entretanto outras métricas podem ser utilizadas para o cálculo da transformada distância, por exemplo vizinhança de 4 "pixels" (diagonais estão a uma distância 2 do "pixel" central) ou distância euclidiana (diagonais estão a uma distância $\sqrt{2}$ do "pixel" central), note então que o resultado para a transformada distância pode variar de acordo com a métrica utilizada.

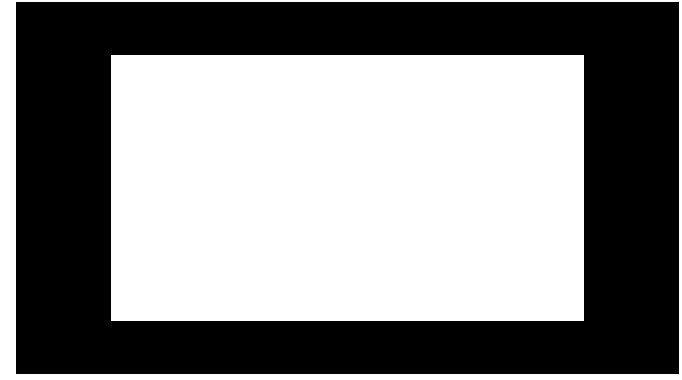

(a)

\begin{tabular}{|c|c|c|c|c|c|c|}
\hline$\underline{0}$ & $\underline{0}$ & $\underline{0}$ & $\underline{0}$ & $\underline{0}$ & $\underline{0}$ & $\underline{0}$ \\
\hline$\underline{0}$ & $\underline{1}$ & $\underline{1}$ & $\underline{1}$ & $\underline{1}$ & $\underline{1}$ & $\underline{0}$ \\
\hline$\underline{0}$ & $\underline{1}$ & $\underline{2}$ & $\underline{2}$ & $\underline{2}$ & $\underline{1}$ & $\underline{0}$ \\
\hline$\underline{0}$ & $\underline{1}$ & $\underline{2}$ & $\underline{3}$ & $\underline{2}$ & $\underline{1}$ & $\underline{0}$ \\
\hline$\underline{0}$ & $\underline{1}$ & $\underline{2}$ & $\underline{2}$ & $\underline{2}$ & $\underline{1}$ & $\underline{0}$ \\
\hline$\underline{0}$ & $\underline{1}$ & $\underline{1}$ & $\underline{1}$ & $\underline{1}$ & $\underline{1}$ & $\underline{0}$ \\
\hline$\underline{0}$ & $\underline{0}$ & $\underline{0}$ & $\underline{0}$ & $\underline{0}$ & $\underline{0}$ & $\underline{0}$ \\
\hline
\end{tabular}

(c)

\begin{tabular}{|c|c|c|c|c|c|c|}
\hline$\underline{0}$ & $\underline{0}$ & $\underline{0}$ & $\underline{0}$ & $\underline{0}$ & $\underline{0}$ & $\underline{0}$ \\
\hline$\underline{0}$ & $\underline{1}$ & $\underline{1}$ & $\underline{1}$ & $\underline{1}$ & $\underline{1}$ & $\underline{0}$ \\
\hline$\underline{0}$ & $\underline{1}$ & $\underline{1}$ & $\underline{1}$ & $\underline{1}$ & $\underline{1}$ & $\underline{0}$ \\
\hline$\underline{0}$ & $\underline{1}$ & $\underline{1}$ & $\underline{1}$ & $\underline{1}$ & $\underline{1}$ & $\underline{0}$ \\
\hline$\underline{0}$ & $\underline{1}$ & $\underline{1}$ & $\underline{1}$ & $\underline{1}$ & $\underline{1}$ & $\underline{0}$ \\
\hline$\underline{0}$ & $\underline{1}$ & $\underline{1}$ & $\underline{1}$ & $\underline{1}$ & $\underline{1}$ & $\underline{0}$ \\
\hline$\underline{0}$ & $\underline{0}$ & $\underline{0}$ & $\underline{0}$ & $\underline{0}$ & $\underline{0}$ & $\underline{0}$ \\
\hline
\end{tabular}

(b)

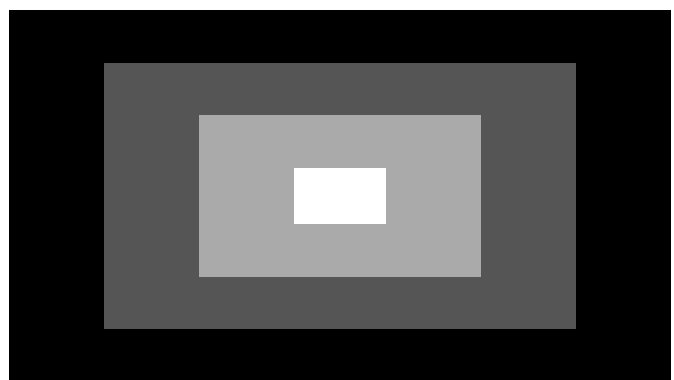

(d)

Figura 2.13 - No canto superior esquerdo, a imagem de entrada para a transformada distância, no canto superior direito, sua representação matricial. No canto inferior esquerdo, a matriz resultante da transformada distância e, no canto inferior direito, a representação gráfica da transformada.

Fonte: Elaborada pelo autor. 


\subsubsection{Dilatação e erosão, abertura e fechamento}

Com base na transformada distância podemos definir o processo de erosão. (24) Aplicando uma limiarização (eq. 2.1) na matrix da transformada distância apenas os valores acima do limiar (mais afastados da borda) farão parte do novo objeto, enquanto que os valores menores que o limiar serão incorporados ao fundo. Tomemos um exemplo, para obtermos a versão erodida da imagem 2.14a aplicamos a transformada distância (vide fig. 2.14b) e em seguida aplicamos uma limiarização com $t=10$, resultado na figura 2.14c.

O efeito básico da operação consiste em erodir as bordas do objeto, reduzindo a área do objeto e aumentando os buracos dentro dele. Note que o limiar $t$ deve ser maior ou igual a dois, e que, quanto maior o valor do limiar maior o valência (ou raio) de erosão do objeto. Note também que se o limiar $t$ for suficientemente alto o objeto pode ser eliminado (imagine um quadrado de lado $L=10$ que foi erodido com um limiar $t=6$ ).

Analogamente podemos definir a operação oposta à erosão. A dilatação (24) pode ser entendida como a erosão dos "pixels" de fundo, para isso podemos aplicar uma simples operação de inversão (trocamos preto por branco, ou o fundo pelo objeto, e vice versa) no início e no fim do processo de erosão. O processo de dilatação aumenta a área do objeto, aumentando as bordas e diminuindo buracos (vide figura 2.15). Caso o limiar $t$ seja suficiente alto, os buracos dentro do objeto podem ser eliminados.

Uma vez que definidas erosão e dilatação, podemos definir abertura e fechamento. (24) O processo de abertura consiste de uma operação de erosão seguida de uma dilatação (ambas com o mesmo limiar) e o processo de fechamento constitui de uma dilatação seguida por uma erosão (novamente ambas com o mesmo limiar).

Note que os processos de abertura e fechamento não retornam necessariamente a imagem ao formato original, ou seja, os processos de dilatação e erosão não se anulam completamente. No 


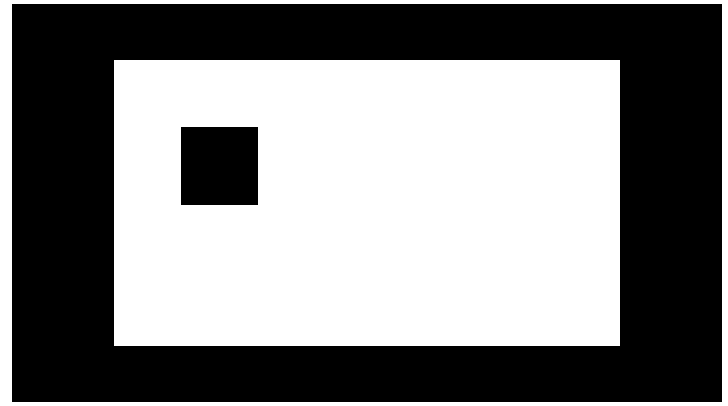

(a)

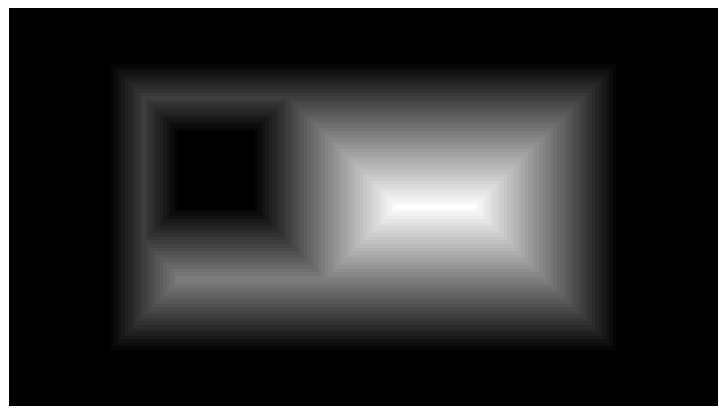

(b)

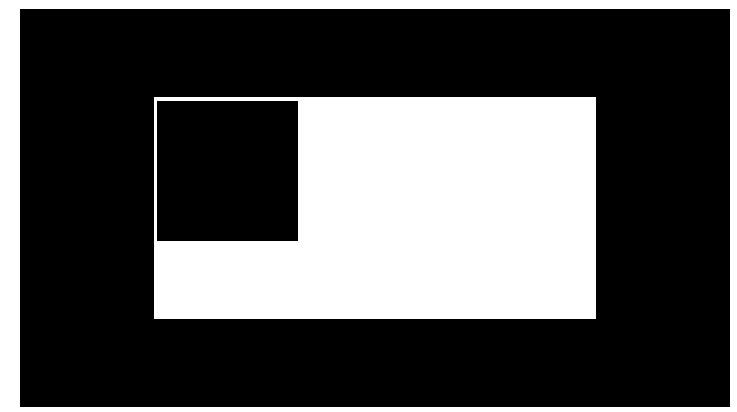

(c)

Figura 2.14 - Imagem original à esquerda e imagem erodida à direita. O limiar para o processo de erosão ét $=10$.

Fonte: Elaborada pelo autor.

processo de abertura os objetos que são aniquilados não são reintroduzidos com o processo de dilatação (mais precisamente todos objetos menores que $\frac{t}{2}$ são aniquilados), enquanto que na operação de fechamento os buracos que foram preenchidos não são reintroduzidos a imagem. Por exemplo: se aplicassemos uma dilatação com limiar $t=12$ na imagem 2.15a o buraco no seu interior seria aniquilado (transformando o objeto em um retângulo) e após isso nenhuma operação de erosão retornaria a imagem ao seu formato original. Além disso, caso tenhamos dois, ou mais, corpos no processo de fechamento, eles podem se conectar formando um novo objeto que não será separado pelo processo de erosão (esse caso será utilizado para reconstruir canais desconexos (vide seções 3.3 e 3.5 ). 


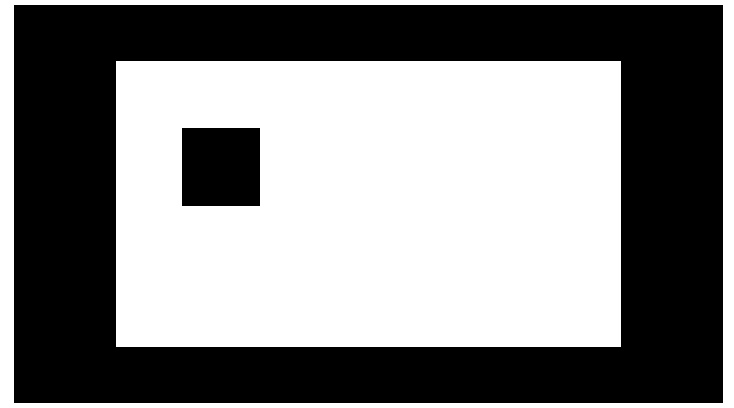

(a)

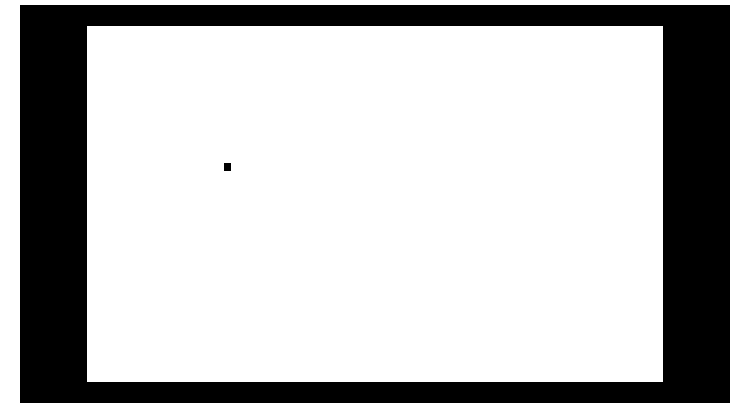

(b)

Figura 2.15 - Imagem original à esquerda e imagem dilatada à direita. O limiar para o processo de dilatação ét $=10$.

Fonte: Elaborada pelo autor.

\subsubsection{Volumes}

Assim como fizemos para imagens devemos definir como objetos tridimensionais, denominados volumes, são representados em um computador. De fato, a representação de volumes é uma generalização da representação de imagens e todos os conceitos definidos para imagens se aplicam a volumes, com a diferença que um volume é representado por uma matriz tridimensional de largura $X$, profundidade $Y$ e altura $Z$. Dessa forma um volume contém um total de $N \times X \times Y \times Z$ elementos, cada um desses elementos é denominado vóxel (volume + "pixel") e possuí uma coordenada $i, j, k$ dentro do volume.

No caso deste estudo os volumes apresentam apenas um canal $(N=1)$ e cada vóxel apresenta apenas dois valores: zero ou um $(q=1)$; simplicando a estrutura para uma matriz tridimensional de zeros e uns. O volume é formado empilhando todas as imagens $2 \mathrm{D}$ em sequência. Imaginando um cubo com a origem do sistema de coordenadas em um dos seus vértices e cada um dos três eixos cartesianos em uma das três arestas, as imagens são empilhadas ao longo do eixo $Z$ e os eixos $X$ e $Y$ coincidem com o plano das imagens, dessa forma a matriz 3D terá dimensões $X=C$ e $Y=R$ e terá dimensão $Z$ igual ao número total de imagens. 


\subsection{Redes complexas}

Usaremos redes complexas para analisar a rede de canais; a representação por redes complexas permite que métodos e algoritmos consagrados sejam utilizados. As próximas secões apresentam uma introdução a redes complexas, seus conceitos básicos e os métodos utilizados.

Para entender redes complexas é essencial o conceito de grafo. Grafos são uma representação abstrata de um conjunto de objetos ligados de alguma forma (25), em um grafo os objetos são representados por estruturas chamadas vértices (ou vértices) e as ligações por estruturas chamadas arestas (ou conexões). Para um melhor entendimento apresentaremos um exemplo: imagine três cidades $A, B$ e $C$, estas cidades são conectadas por estradas, de tal forma que a cidade $A$ possui uma estrada até a cidade $B$ e uma estrada até a cidade $C$, mas não existe nenhuma estrada ligando as cidades $B$ e $C$, esse exemplo pode ser representado por um grafo onde as cidades são vértices e as estradas são arestas.

Grafos podem ser representados graficamente, de forma que os vértices são representados por pontos ou circunferências e as arestas são representadas por linhas ligando esses pontos, a figura 2.16 ilustra o grafo do exemplo acima.

Dizemos que redes complexas são grafos com características topológicas não triviais, em contraste com "lattices", que são compostas por regras bem estabelecidas, ou grafos aleatórios, que também são previsíveis devido a análise estatística. Em geral essas características são encontradas em representações de sistemas físicos reais, exemplos clássicos incluem a internet (10), interações sociais (12) e comportamento de proteínas. (13) 


\subsubsection{Grafos}

Antes de continuarmos algumas nomenclaturas e conceitos sobre grafos/redes complexas devem ser definidos. (26) Matematicamente um grafo $G(\vartheta, \varepsilon)$ é definido como um conjunto de vértices $\vartheta$ e um conjunto de arestas $\varepsilon$ onde cada elemento $[u, v]$ do conjunto $\varepsilon$ conecta apenas um par de vértices $u, v \in \vartheta$ apenas uma vez (não pode haver mais que uma aresta ligando um par $u, v)$.

Algumas observações devem ser feitas:

- Atenção para a notação das arestas entre colchetes $[u, v]$.

- Representaremos por $|\vartheta|$ e $|\varepsilon|$ a número de elementos presentes nos conjuntos $\vartheta$ e $\varepsilon$ respectivamente.

- Os conjuntos $\vartheta$ e $\varepsilon$ podem ser infinitos.

- Um grafo pode conter vértices sem nenhuma ligação (vértice isolado).

- A ligação $[u, u]$ é válida e é denominada de loop.

- Quando $[u, v] \neq[v, u]$ temos um grafo direcionado, ou grafo orientado, ou dígrafo (vide fig. 2.17).

- Quando $[u, v]=[v, u]$ temos um grafo não direcionado.

- Um grafo não direcionado sem loops é denominado um grafo simples. As três redes deste trabalho são grafos simples (vide seção 3.5).

- Definimos como grafo geográfico aqueles em que os vértices possuem uma posição no espaço euclidiano. 
- Grafos onde há várias arestas ligando o mesmo par $u, v$ são denominados multigrafos (neste caso as arestas normalmente recebem rótulos para distingui-las).

- Hipergrafos permitem que uma aresta ligue dois ou mais elementos de uma vez (podemos ter elementos como $[u, v, w]$ onde $u, v, w \in \vartheta)$.

- Arestas podem ter um peso associado que defini a força de interação entre os vértices (vide fig. 2.17).

- Um componente de um grafo é um subgrafo $H(\theta, \epsilon)$, $\operatorname{com} \theta \subset \vartheta$ e $\epsilon \subset \varepsilon$, onde para quaisquer dois vértices $u, v \in \epsilon$ existe um caminho ligando $u$ e $v$.

- Podem existir combinações entre todos esses casos, por exemplo: um multidígrafo é um multigrafo com relações direcionais.

Para ilustrar alguns dos conceitos acima tomemos como exemplo três pessoas $A, B$ e $C$, onde $A$ e $B$ se conhecem a muito tempo (aresta com peso alto), $B$ já ouviu falar de $C$ (aresta com peso baixo) e $C$ não conhece nem $A$ nem $B$. Este grafo seria representado pelo grafo da figura 2.17 . 


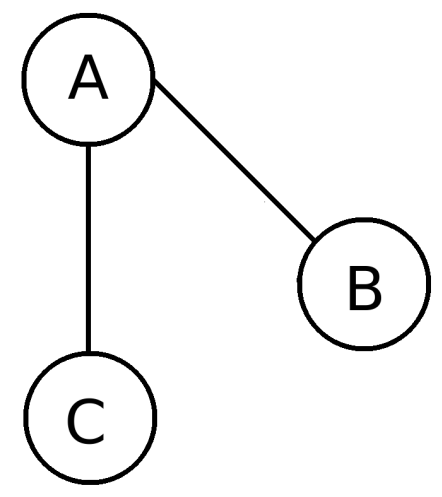

Figura 2.16 - Representação gráfica de um grafo. No caso, o grafo apresenta o exemplo de três cidades $A, B, C$ ligadas (ou não) por rodovias.

Fonte: Elaborada pelo autor.

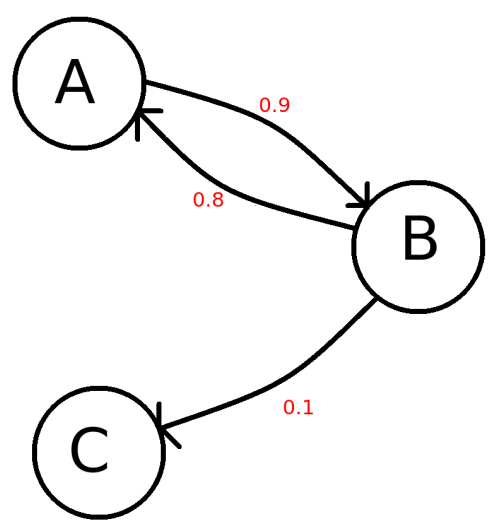

Figura 2.17 - Exemplo de um grafo direcionado e com pesos.

Fonte: Elaborada pelo autor. 


\subsubsection{Valência}

Um atributo fundamental dos vértices de uma rede é a valência (ou mais comumente valência) de um nó. Representada por $k_{u}$ a valência defini a quantidade de arestas associadas ao vértice $u$ (sendo que loops são contados duas vezes) (26). Os vértices com quem $u$ se liga são denominados vizinhos de $u$ (com exceção dele próprio). Tomando a figura 2.16 como exemplo podemos dizer que: $k_{A}=2, k_{B}=1$ e $k_{C}=1$. Em um dígrafo devemos fazer distinção entre arestas incidentes no vértice (valência de entrada) e arestas originadas do nó (valência de saída). Vértices com valência igual a um são chamados de vértices folha, vértices com quantidade de arestas muito maior que a média são chamados hubs.

\subsubsection{Caminho}

Para definirmos componentes precisamos definir conceito de caminho entre $u$ e $v$. Um caminho de comprimento $l$ é definido como uma sequência alternada de arestas e vértice (distintos) $u_{0}$; $\left[u_{0}, u_{1}\right] ; u_{1} ;\left[u_{1}, u_{2}\right] ; u_{2} \ldots u_{l-1} ;\left[u_{l-1} v\right] ; v\left(\right.$ note que $\left.u_{l}=v\right)$ que conectam dois vértices $u$ e $v(26)$. Note que esse conceito pode ser generalizado para caminhos de comprimento infinito.

\subsubsection{Fluxo máximo}

Suponha que um nó $s$ de uma rede produza algum material a uma taxa temporal $f_{s}$, ao mesmo tempo um nó $e \neq s$ consome esse material a uma taxa $f_{e}=f_{s}$ enquanto todos os outros vértices da rede são conservativos, ou seja, não criam nem destroem o material. Cada aresta do grafo possui uma capacidade máxima de condução do material definida pelo peso da rede (valor não negativo). Assim, fluxo pode ser definido como a quantidade de material passando por um nó (ou aresta) por unidade de tempo (não confundir com o conceito físico que quantifica quantidade 
de material por tempo por área). (26)

O problema de fluxo máximo consiste em saber a quantidade máxima de material que pode sair de $s$ e chegar em $e$ por unidade de tempo sem exceder a capacidade das arestas. Para isso utilizamos o método de Ford-Fulkerson (27), o algoritmo consiste em enquanto houver qualquer caminho com capacidade livre ligando $s$ a $e$ o material é enviado por esse caminho.

Dois outros métodos são dignos de nota. O primeiro é o algoritmo de Edmonds-Karp $(28,29)$ que se trata de uma implementação do algoritmo de Ford-Fulkerson com tempo de execução $O\left(|\vartheta||\varepsilon|^{2}\right)$ e o outro é o algoritmo de Dinitz $(30,31)$ com tempo de execução $O\left(|\varepsilon \| \vartheta|^{2}\right)$.

\subsubsection{Ataques e falhas}

Denomina-se de ataque qualquer mudança indesejada na topologia da rede, em geral trata-se da remoção de um ou de um conjunto de arestas e/ou vértices. São classificados em dois tipos: sistemáticos ou aleatórios, sendo que o último geralmente recebe o nome de falhas, enquanto que o termo ataque expressa ataques sistemáticos (seguem alguma regra de execução).

Com base nisso torna-se útil definir a robustez (ou resistência, ou tolerância) a ataques de uma rede como o comportamento de alguma característica da rede contra a quantidade de ataques realizadas (ou vértices/arestas removidas), por exemplo, podemos medir o tamanho da rede (número de vértices) em relação a quantidade de ataques realizados. Note que nesse caso número máximo de ataques realizados é o próprio tamanho da rede. 


\subsubsection{Comunidades}

Podemos definir como comunidade um subgrafo $H(\theta, \epsilon) \in G(\vartheta, \varepsilon)$ em que a quantidade de arestas ligando dois vértices $u$ e $v(\operatorname{com} u, v \in \theta)$ é maior que a quantidade de arestas que ligam $H(\theta, \epsilon)$ a $G(\vartheta, \varepsilon)$, ou seja, podemos definir comunidades como um conjunto de vértices que se ligam mais entre eles do que com o resto da rede. Para quantificar este comportamento usaremos uma grandeza proposta por Clauset. (32)

Seja $A_{u, v}$ um elemento da matriz de adjacência onde:

$$
A_{u, v}= \begin{cases}1, & \text { se os vértices } u \text { e } v \text { são conectados } \\ 0, & \text { caso contrário }\end{cases}
$$

Supondo que um nó $u$ pertença a uma comunidade $c_{u}$ e o nó $v$ pertença a uma comunidade $c_{v}$ podemos definir a modularidade $Q$ como:

$$
Q=\frac{1}{2|\varepsilon|} \sum_{u, v}\left[A_{u v}-\frac{k_{u} k_{v}}{2|\varepsilon|}\right] \delta\left(c_{u}, c_{v}\right)
$$

Onde $|\varepsilon|$ é o número de vértices da rede, $k_{u}$ e $k_{v}$ são respectivamente a valência do nó $u$ e do nó $v$, e $\delta\left(c_{u}, c_{v}\right)$ é distribuição delta de Dirac. Quando os vértices $u$ e $v$ pertencem a mesma comunidade $\left(c_{u}=c_{v}\right.$ e $\left.\delta\left(c_{u}, c_{v}\right)=1\right)$ o valor $A_{u v}-\frac{k_{u} k_{v}}{2|\varepsilon|}$ é adicionado em $Q$, e quando $u$ e $v$ não pertencem a mesma comunidade $\left(\delta\left(c_{u}, c_{v}\right)=0\right)$ o valor de $Q$ não se altera, ao final o valor da soma é divido por duas vezes o número de arestas. 


\subsubsection{Redes aleatórias}

Redes aleatórias são grafos onde as ligações ocorrem de maneira aleatória (em contraste com "lattices" onde as ligações obedecem a uma lei de construção) e por consequência redes aleatórias não possuem uma função específica nem demostram qualquer comportamente oriundo de alguma característica fundamental da rede. Assim, qualquer comportamento divergente do apresentado por uma rede aleatória indica a existência de estrutura que é destinada para uma função específica ou que é consequência de uma propriedade básica. Dessa forma, é fundamental compararmos o as redes deste trabalho com análogos aleatórios.

O comportamento apresentado por essas três redes foi comparado ao comportamento apresentado por redes aletórias. Vários modelos para redes aleatórias existem sendo o mais famoso o proposto por Erdős e Rényi (33), nesse método os análogos aleatórios são criados definindo $|\vartheta|$ vértices isolados, em seguida um par de vértices é sorteado e esses vértices são ligados por uma aresta, esse processo é repetido até que a rede aleatória possua $|\varepsilon|$ arestas, onde $|\vartheta|$ e $|\varepsilon|$ são respectivamente o número de vértices e o número de arestas da rede original. 


\section{Capítulo 3}

\section{Desenvolvimentos e resultados}

Para remontar as lâminas usamos uma técnica conhecida como "image stitching" (costura de imagens). Encontrada nas câmeras digitais modernas essa técnica combina várias imagens em uma só (fotos panorâmicas). Composta por três partes (registro, calibração, montagem):

1. Registro - Primeiro, particularidades de cada imagem (denominados pontos chave) são encontradas utilizando um descritor baseado em gradiente. Em seguida os pontos chave de duas imagens são comparados par-a-par, caso haja correspondência os dois pontos chaves são promovidos a um ponto de controle. Este processo é repetido para todas as imagens e os pontos de controle resultantes são utilizados para fazer o alinhamento.

2. Calibração - Este processo tenta corrigir discrepâncias introduzidas pelo conjunto câmera lente (e.g.: aberração cromática, distorção, vinheta, diferença de exposição).

3. Montagem - Aplica as correções do processo de calibração e remapeia as imagens de acordo com os pontos de controle e a projeção utilizada.

Sobre projeções note que como toda foto é a representação de um objeto 3D em um plano, as fotografias apresentam uma versão distorcida do formato real (especialmente na região das 
bordas), isso se torna especialmente importante quando tentamos juntar as extremidades de duas imagens, logo o processo de montagem deve corrigir estas distorções.

As imagens são compostas utilizando a libpanotools $(34,35)$ disponível através do Hugin. (36) Cada uma das imagens começa com uma resolução de $2048 \times 1536$ (vide figuras 2.3 e 2.4) e as imagens resultantes têm resolução aproximada de $3824 \times 2592$, que embora interessante para a qualidade da reconstrução é computacionalmente exigente (tanto em termo de memória quanto tempo de processamento), dessa forma as imagens terão a resolução reduzida para $1000 \times 1000$.

Seguimos uma abordagem minimalista mantendo as imagens com o mínimo de modificações possível (etapa de calibração praticamente nula), mais especificamente utilizamos correção de balanço de branco para minimizar diferenças de tons entre as várias regiões da imagem e projeção equiretangular com os ângulos de campo de visão (vertical e horizontal) da ordem $5^{\circ}$. A figura 3.1 mostra a primeira lâmina do osso 2 após o processo de costura, note a introdução de bordas pretas à imagem.

\subsection{Tratamento de bordas}

Dois dos próximos passos, filtragem e registro (vide seções 3.2 e 3.4, respectivamente), podem causar anomalias (artefatos) nas regiões próximas às extremidades das imagens, assim é necessário algum tratamento dessa região antes de prosseguir.

A figura 3.1 apresenta as quatro grandes estruturas contidas nas imagens: a primeira delas é a borda exterior (em preto) introduzida no processo de costura, a segunda é o fundo (em cinza claro) contra o qual a lâmina foi fotografada, a terceira é a matriz óssea (em cinza escuro), e a última são os canais (também em cinza claro) compreendidos dentro da matriz óssea. 


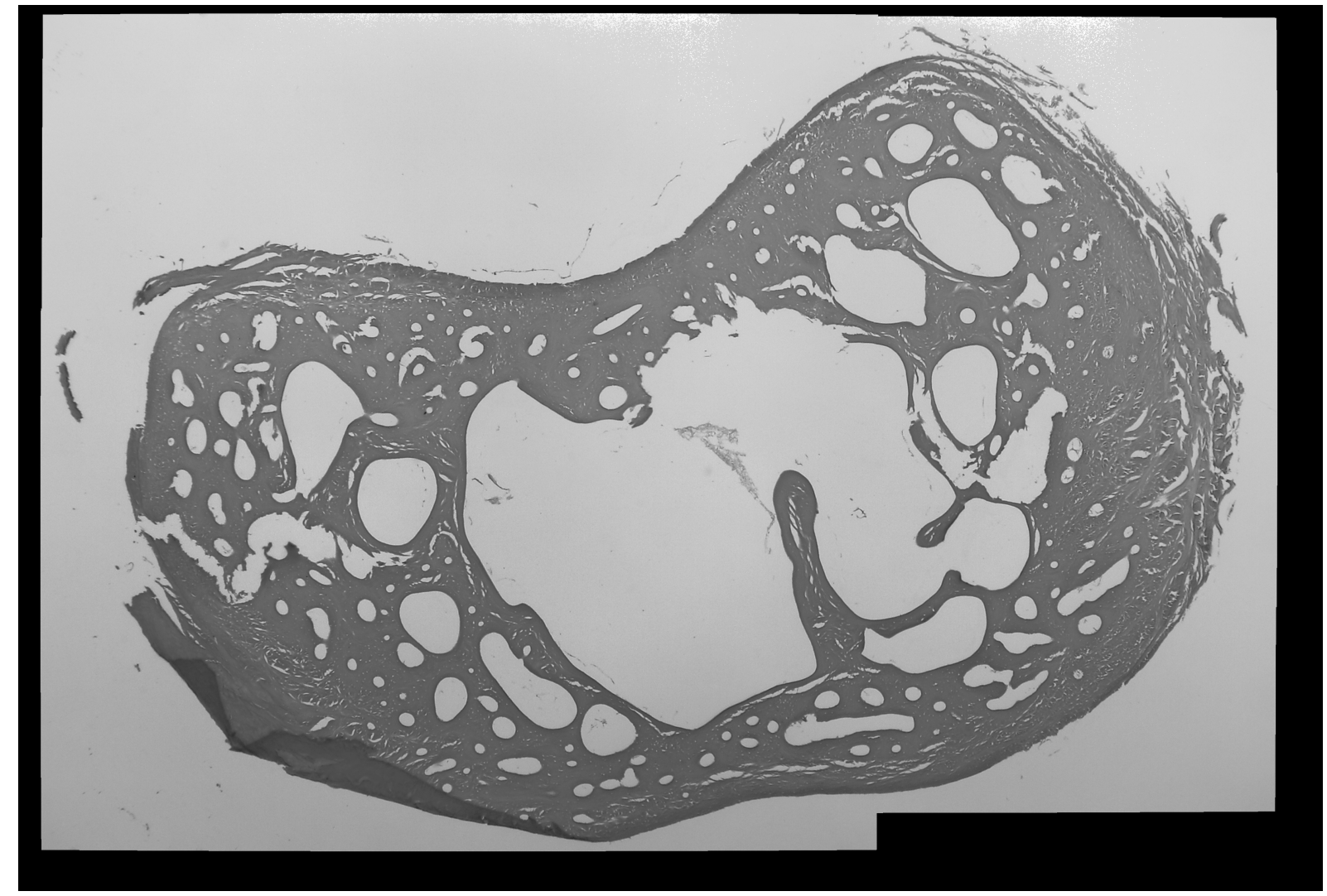

Figura 3.1 - Primeira lâmina do osso 2 remontada a partir das quatro imagens setorizadas vistas na figura 2.4 .

Fonte: Elaborada pelo autor.

O tratamento constitui de uma mudança da cor da borda, passando de preto para uma cor semelhante a cor de fundo (cinza claro). O tom cinza claro corresponde aos "pixels" com valores acima do valor médio da figura (média global), sendo assim usamos a média dos tons claros (tons acima da média global) como a nova cor da borda. Ao mesmo tempo, as bordas foram alargadas deixando uma margem entre a matriz óssea e lados da imagem, a razão para isso pode ser vista na seção 3.4. A figura 3.2 mostra a imagem após os dois passos, note que embora a nova cor da borda não coincida exatamente com a cor do fundo essa diferença será resolvida posteriormente no processo de filtragem (vide seção 3.2). 


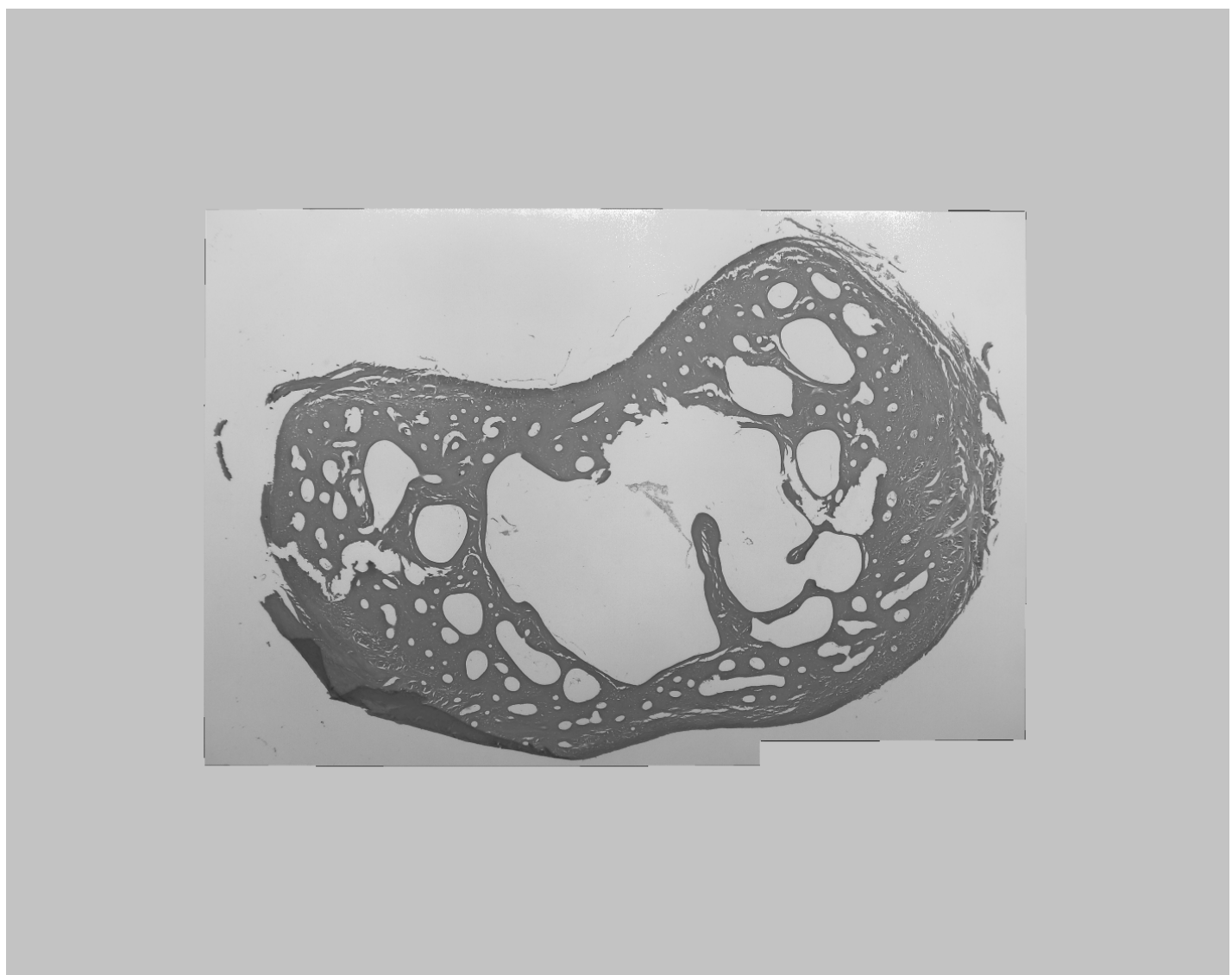

Figura 3.2 - Imagem após o tratamento de bordas.

Fonte: Elaborada pelo autor.

\subsection{Método da janela deslizante}

Como primeira abordagem para segmentar os canais tentamos limiarização direta, entretanto algumas das imagens apresentam uma variação vertical na tonalidade que não permite uma limiarização direta mesmo utilizando o método de Otsu (vide figura 3.3), logo outro método é necessario para segmentar todo o conjunto de imagens.

O método da janela deslizante consiste de uma janela de tamanho $l \times l$ que percorre toda a imagem "pixel” por "pixel". Para cada "pixel” da imagem, a média dos "pixels" seus vizinhos (dentro da janela) é calculada e em seguida o valor do ponto é subtraído do valor da média. 


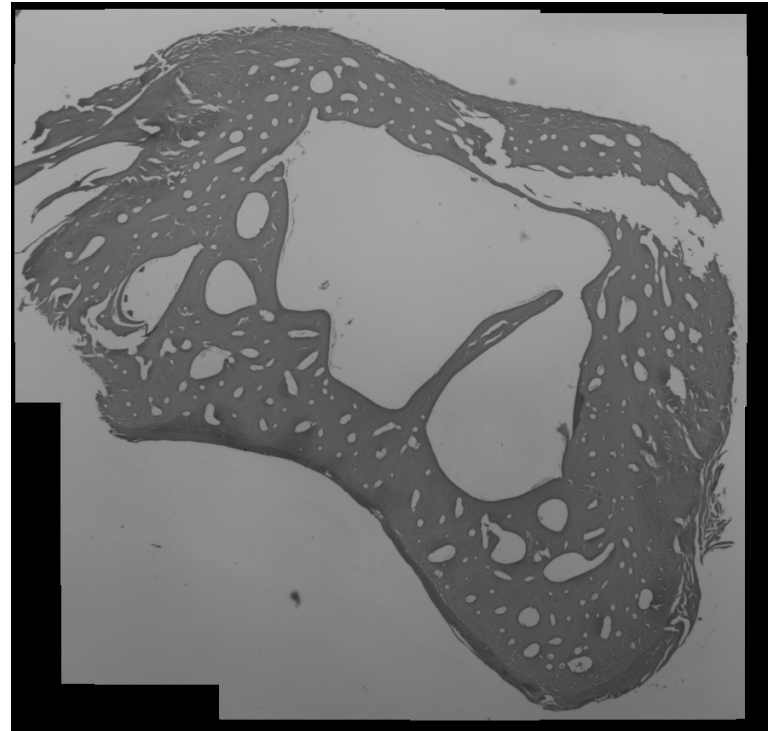

(a)

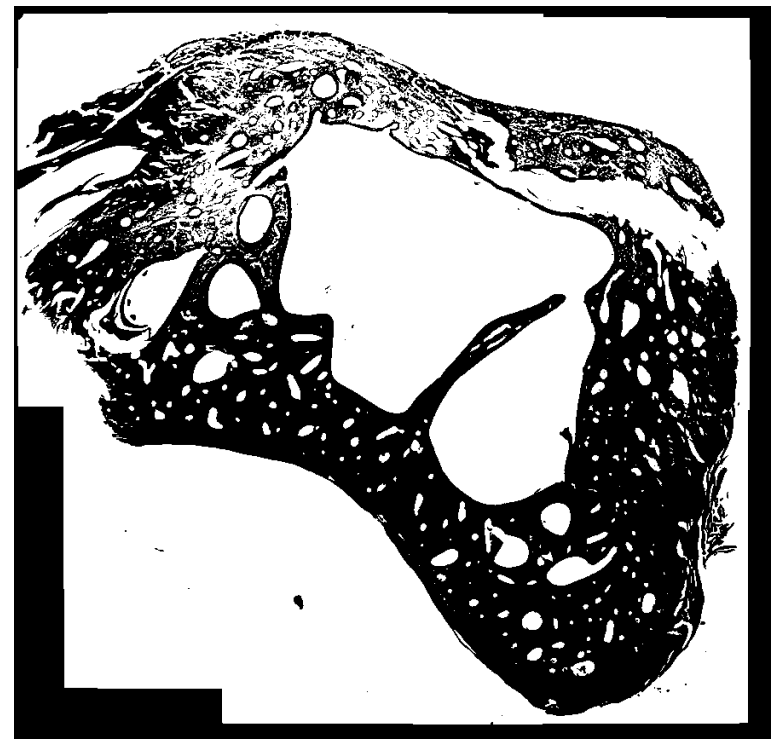

(b)

Figura 3.3 - Primeira lâmina do osso 1 (à esquerda), note como o canto superior direito é levemente mais claro que o restante da imagem. À direita, a binarização obtida pelo método de Otsu, note que apenas o método de Otsu não é capaz de diferenciar os canais da matriz óssea.

Fonte: Elaborada pelo autor.

Essa imagem é então normalizada e as bordas periódicas (vide seção 3.1) são descartadas, o resultado dessa operação pode ser visto na segunda imagem da figura 3.4.

O método produz duas variações na nova imagem. A primeira é a redução no gradiente de cor (degradê) da imagem (as partes superior e inferior apresentam tonalidade mais semelhante) e a segunda é a redução do contraste (o osso e o fundo ficam com tons mais parecidos). 


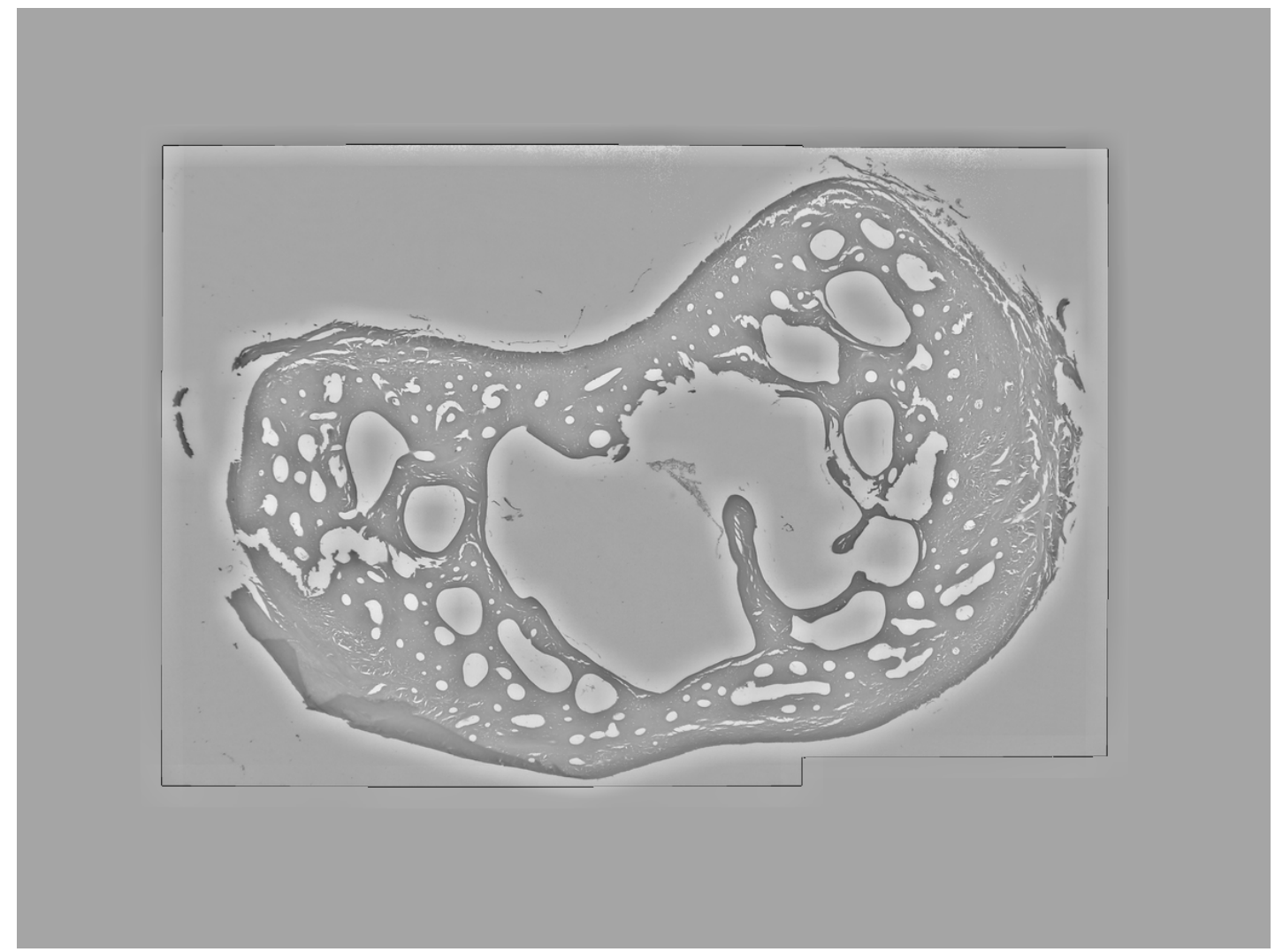

Figura 3.4 - Figura 3.2 após o processo de filtragem. O processo possuia janela de tamanho $l=50$.

Fonte: Elaborada pelo autor.

\subsection{Segmentação e remoção de ruído}

Segmentação é o nome dado ao processo que distingue vários objetos em uma imagem. Nosso cérebro realiza esse processo a todo o momento e, o que parece um dos temas mais intuitivos para a nossa mente, é, de fato, um dos mais difíceis em processamento de imagens.

Usaremos duas técnicas relativamente simples para segmentar os canalículos. A primeira delas é a binarização (vide seção 2.2.1) e o valor para o limiar é o tom do fundo (note que cada imagem possuirá um limiar diferente), a figura 3.5 mostra a matriz óssea em branco sobre um fundo preto, note que esta etapa é acompanhada de ruído proveniente do fundo claro da imagem. 


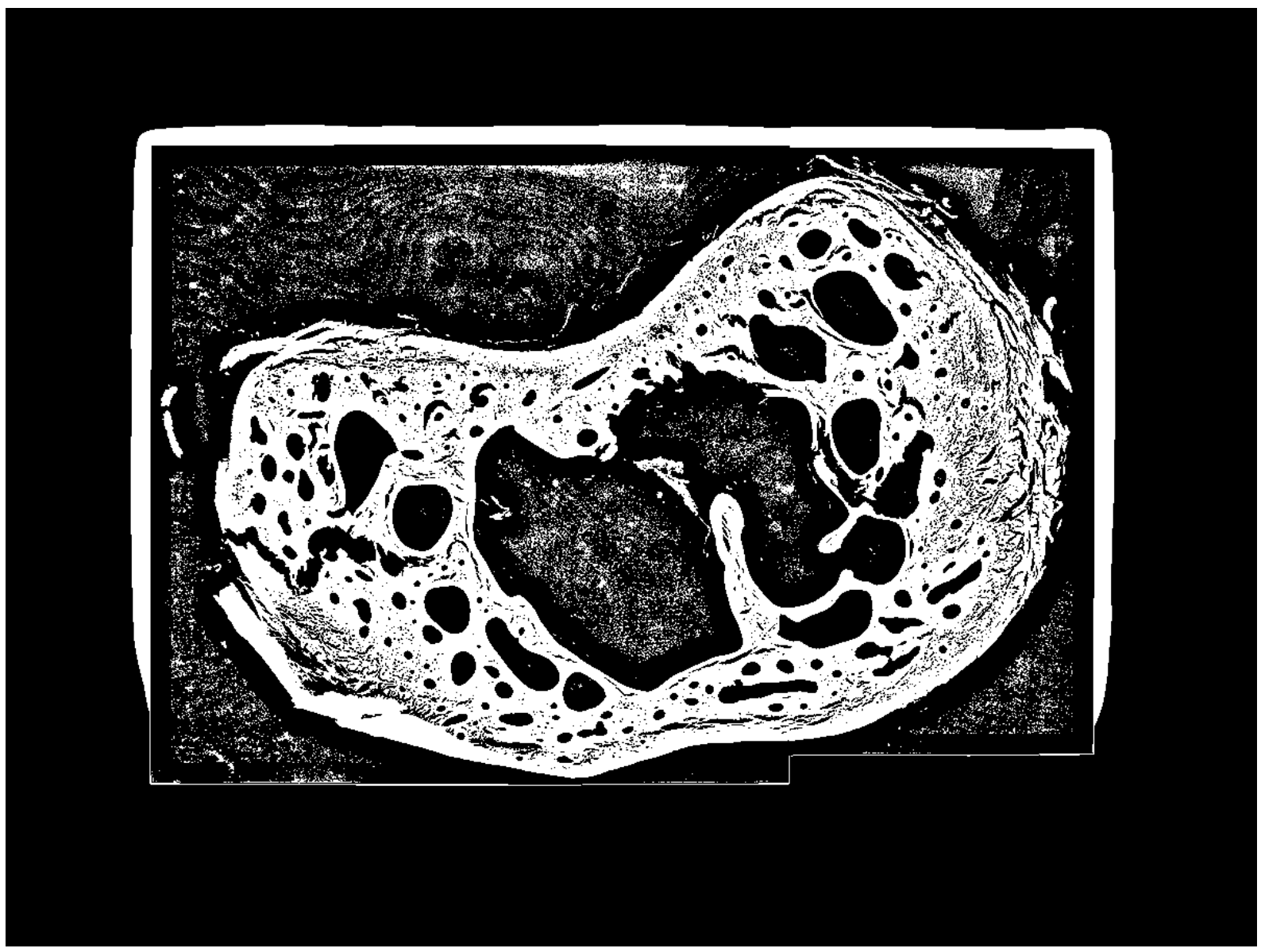

Figura 3.5 - Imagem após o processo de binarização. O limiar escolhido é o tom de fundo da imagem original.

Fonte: Elaborada pelo autor.

Com a imagem em preto e branco podemos utilizar o método de detecção de corpo contínuo.

Desse modo vemos que o maior componente da imagem é o fundo, e que o segundo maior componente corresponde à matriz óssea, e que os outros componentes são ou canais ou ruídos. A figura 3.6 mostra a segmentação obtida para a matriz óssea (lembre que estamos interessados na rede de canais e que a segmentação da estrutura óssea é um subproduto do processo).

Com base no inverso da imagem 3.6 podemos reaplicar o método de detecção de corpo contínuo e selecionar apenas os canais para obtermos a figura 3.7 .

Note que a separação por corpo contínuo também é um processo de remoção de ruídos, embora 


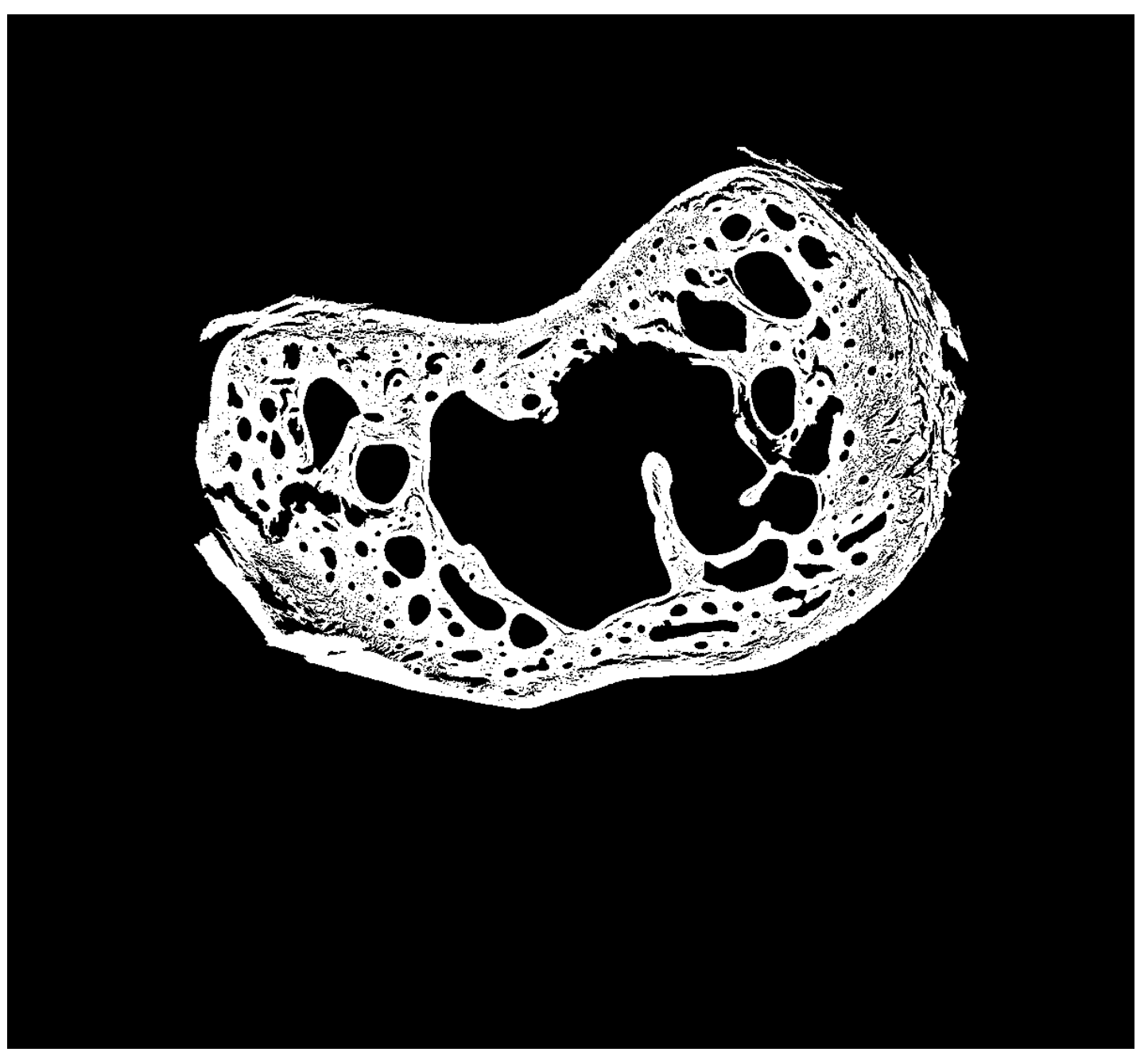

Figura 3.6 - Segmentação da matriz óssea.

Fonte: Elaborada pelo autor.

não suficiente para a reconstrução. Utilizaremos o método de detecção de corpo contínuo aliado a outros discriminantes para segmentarmos os canalículos.

Na figura 3.7, há dois tipos de estruturas indesejáveis, introduzidas pelo processo de limiarização, que devem ser removidas. O primeiro tipo são estruturas similares a pequenos canais (conjuntos menores que 70 "pixels") que, devido ao tamanho reduzido, não contêm informação apreciável sobre a rede e trazem prejuízos posteriores durante a etapa de registro (seção 3.4). O segundo tipo são estruturas pontiagudas, com bordas irregulares e reentrâncias que embora não tragam 


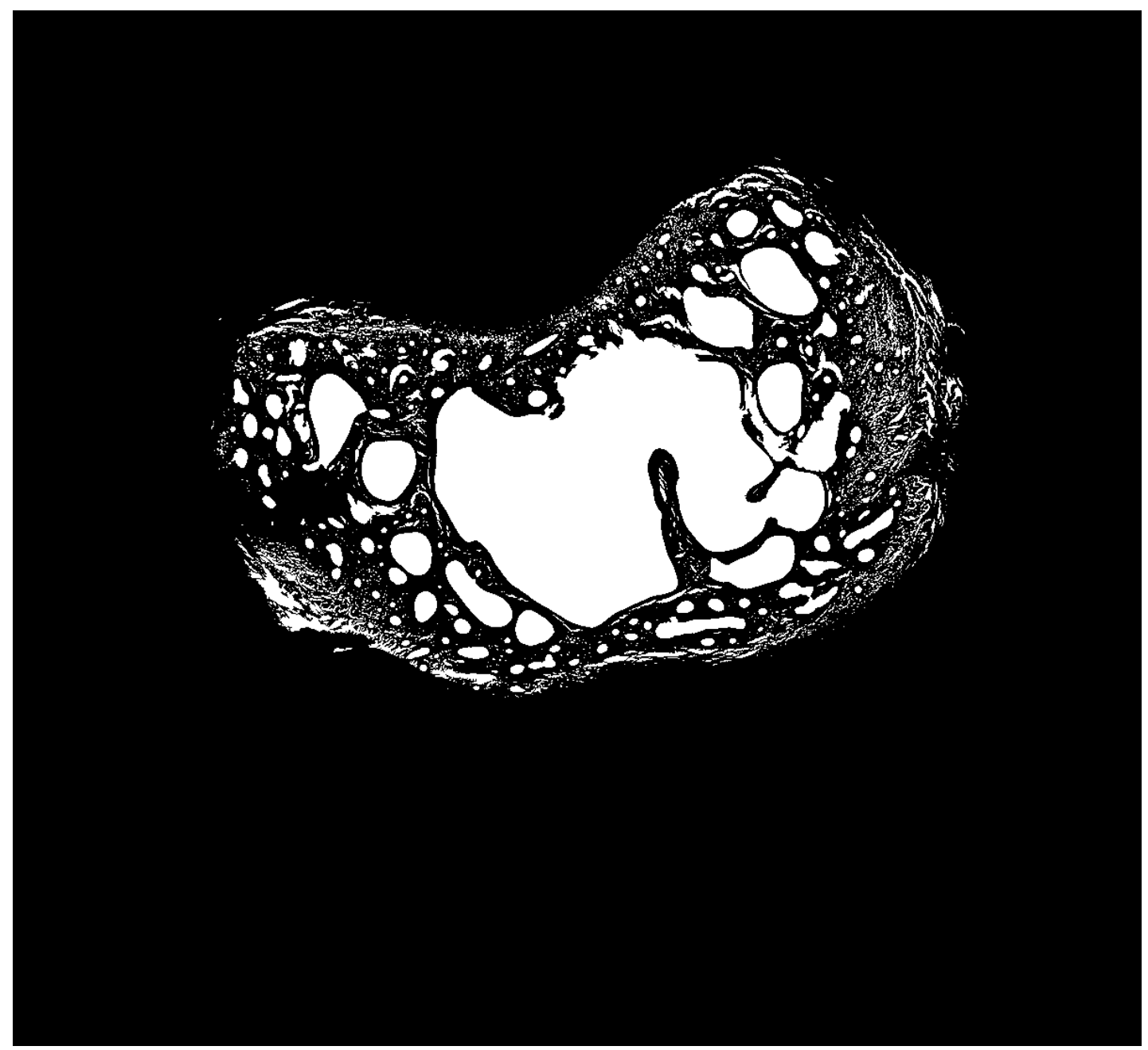

Figura 3.7 - Segmentação da rede de canais.

Fonte: Elaborada pelo autor.

complicações posteriores não refletem a topologia real da rede.

Para os pequenos canais utilizaremos o tamanho do componente como discriminante e para os artefatos upontiagudos tilizaremos o fator de forma. Cada componente conexo tem seu tamanho e seu fator de forma calculados, e baseado nesses valores os componentes são, ou não, removidas da imagem. Note que a remoção de ruído como implementada aqui pode gerar inconsistências entre as várias lâminas, bem como remover erroneamente algum componente que deveria ser mantida; este fato é conhecido e os segmentos ausentes serão recuperados posteri- 


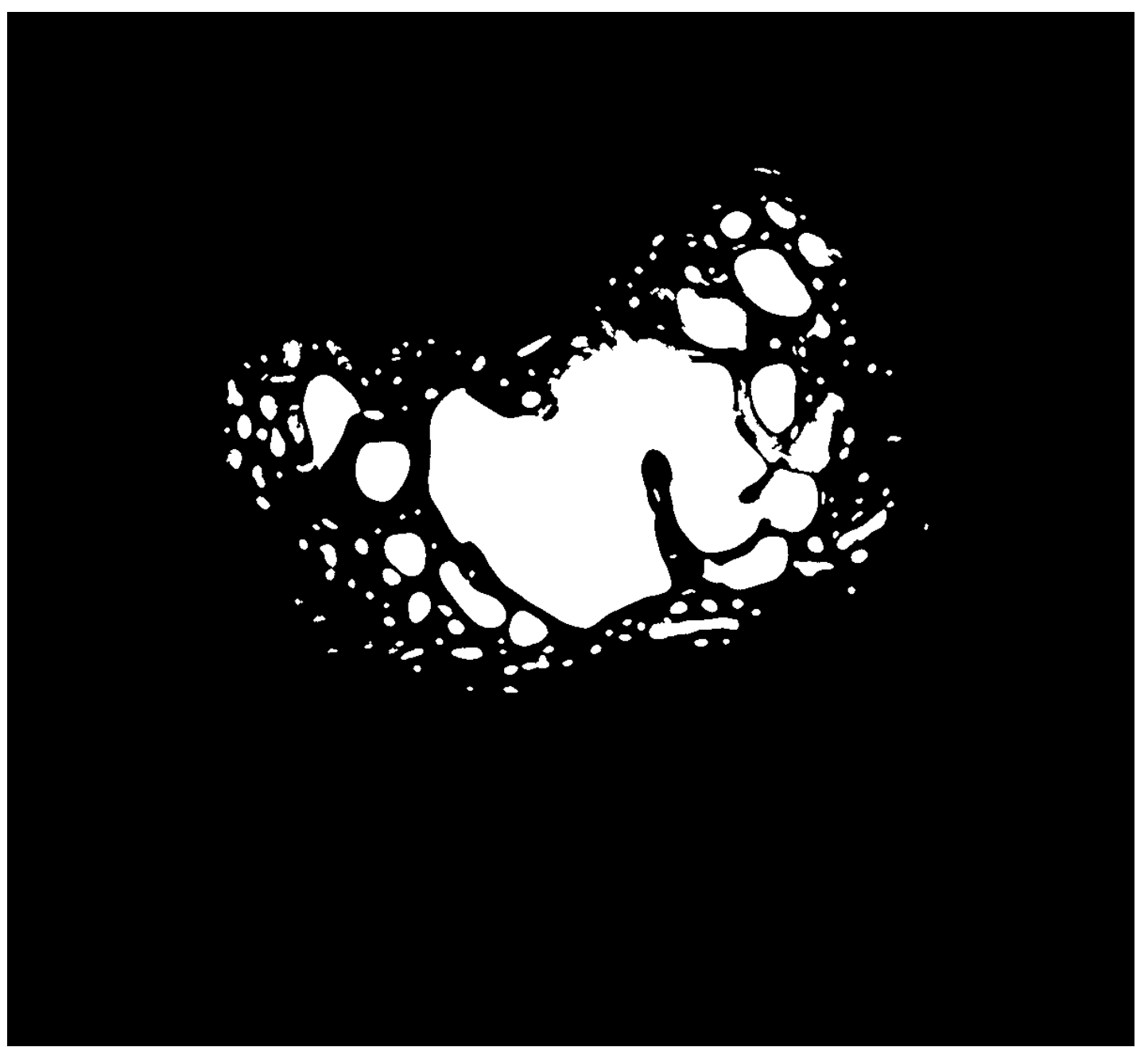

Figura 3.8 - Imagem após a remoção de ruídos.

Fonte: Elaborada pelo autor.

ormente (seção 3.5). A figura 3.8 mostra o resultado da remoção de ruídos. 


\subsection{Registro}

O registro (ou alinhamento) das imagens é necessário, visto que o processo de corte histológico não garante que as lâminas permaneçam alinhadas (vide seção 2.1). Já utilizamos esta técnica anteriormente (capítulo 3), porém com finalidade diferente. Lá utilizamos alinhamento entre várias imagens para formar uma imagem completa, aqui o alinhamento é realizado entre várias imagens para retomarmos a forma original dos canalículos. É importante que esta seja a última etapa antes da reconstrução pois que quaisquer objetos que não os canais (ruídos e artefatos) tornam o alinhamento menos preciso. A borda adicionada na seção 3.1 impede erros devido a uma translação para fora dos limites da imagem.

As figuras 3.9 e 3.10 mostram, respectivamente, as duas primeiras lâminas do osso 2 antes e depois do registro. Note na figura 3.10 algumas poucas inconsistências entre as duas imagens (vide seção 3.3).

Por último, o registro foi feito utilizando a opção de corpo rígido do "Stackreg” (37), um plugin baseado no "Turboreg" (38-40) para "ImageJ" (41). O "ImageJ" também foi utilizado para vizualizar as reconstrução 3D na próxima seção. 

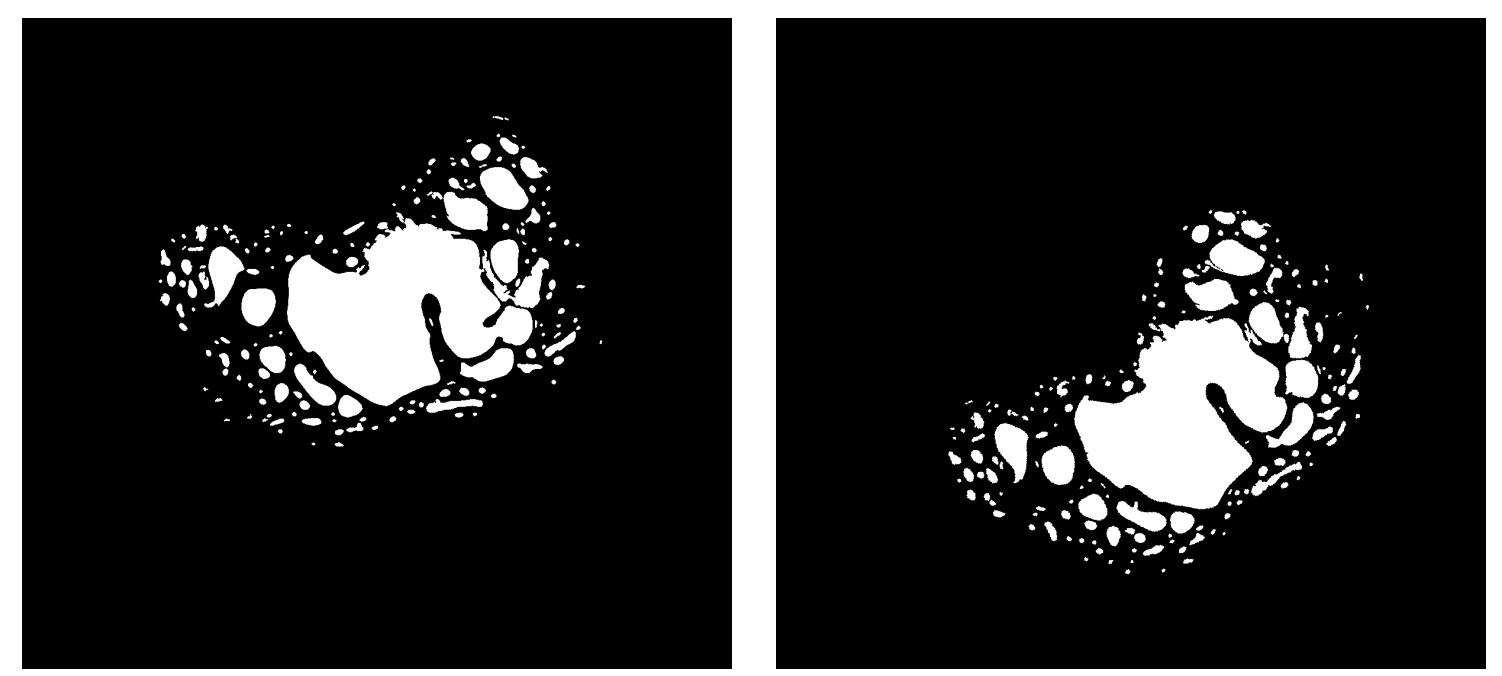

Figura 3.9 - Primeira e segunda lâminas do osso 2 antes do processo de registro.

Fonte: Elaborada pelo autor.
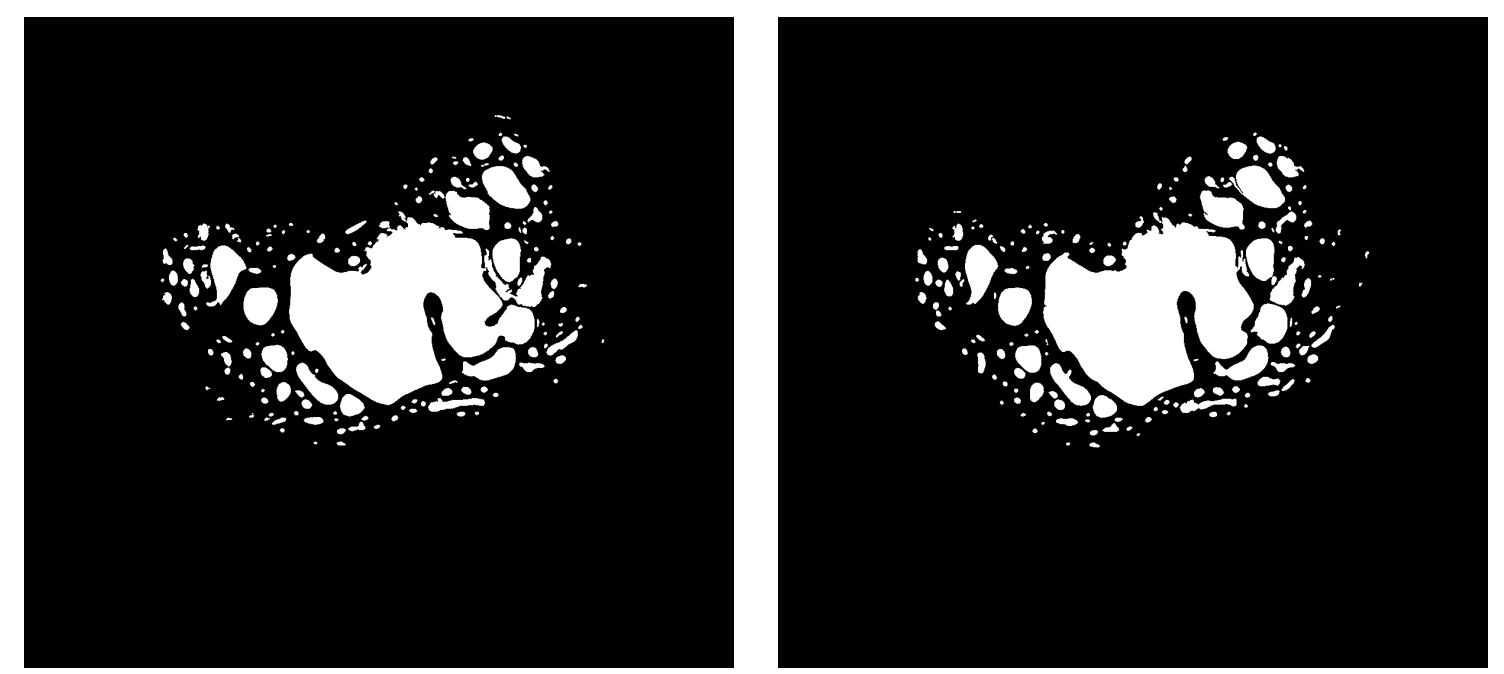

Figura 3.10 - Primeira e segunda lâminas do osso 2 depois do processo de registro.

Fonte: Elaborada pelo autor. 


\subsection{Reconstrução 3D}

Antes de renderizar o volume precisamos garantir a continuidade entre os segmentos (lembrese que a remoção de ruído, como implementamos, não garante tal continuidade), isso é feito com uma operação de fechamento em 3D. Como já descrito na seção 2.2.6 esta operação pode recompor segmentos desconexos caso o raio da dilatação seja suficientemente grande (no nosso caso $t=3$ ). As reconstruções tridimensionais das redes de canais dos ossos 1 e 2 podem ser vista nas figuras 3.11 e 3.12 respectivamente.

Para construir a rede complexa devemos obter o esqueleto das redes de canais. Esqueletos são obtidos aplicando a transformada distância ao volume da rede de canais e em seguida encontrando os máximos locais. A figura 3.13 apresenta um segmento do esqueleto do osso 2.

O processo de construção é quase que imediato se dispusermos do esqueleto da rede. Podemos obter o grafo correspondente classificando cada voxel do esqueleto de acordo com seu número de vizinhos, três casos são possíveis:

1. No primeiro caso o ponto possui apenas um vizinho. Esse ponto é um extremo da rede de canais e será representado no grafo como um vértice folha (ou nó folha).

2. No segundo, o ponto apresenta dois vizinhos. Esse ponto é uma ligação entre dois vértices (um caminho) e representa uma aresta do grafo.

3. No terceiro, o ponto apresenta três ou mais vizinhos. Nesse caso temos nó do grafo. 
Ao mesmo tempo, para todos os vértices (primeiro e terceiro caso) armazenamos sua posição (coordenadas $\mathrm{x}, \mathrm{y}, \mathrm{e} \mathrm{z}$ ), isso nos permitirá visualizar o grafo com cada nó em sua posição original (grafo geográfico). Note que por construção as redes de canis são grafos simples e não há vértices com valência igual a dois (vide 2.3.2).

Características dos canais como o tamanho ou formato não foram armazenadas e, consequentemente, nossas observações não levarão em conta estes aspectos. Note que estas características provavelmente apresentam fatores relavantes para o funcionamento da rede e podem ser inclusos em um trabalho posterior.

As figuras 3.14 e 3.15 mostram, respectivamente, as redes complexas para o osso 1 e o osso 2 . A figura 3.16 apresenta a rede em(1-3) e será usada para fins de comparação (note que a rede Viana não foi feita por um processo inteiramente automatizado). 


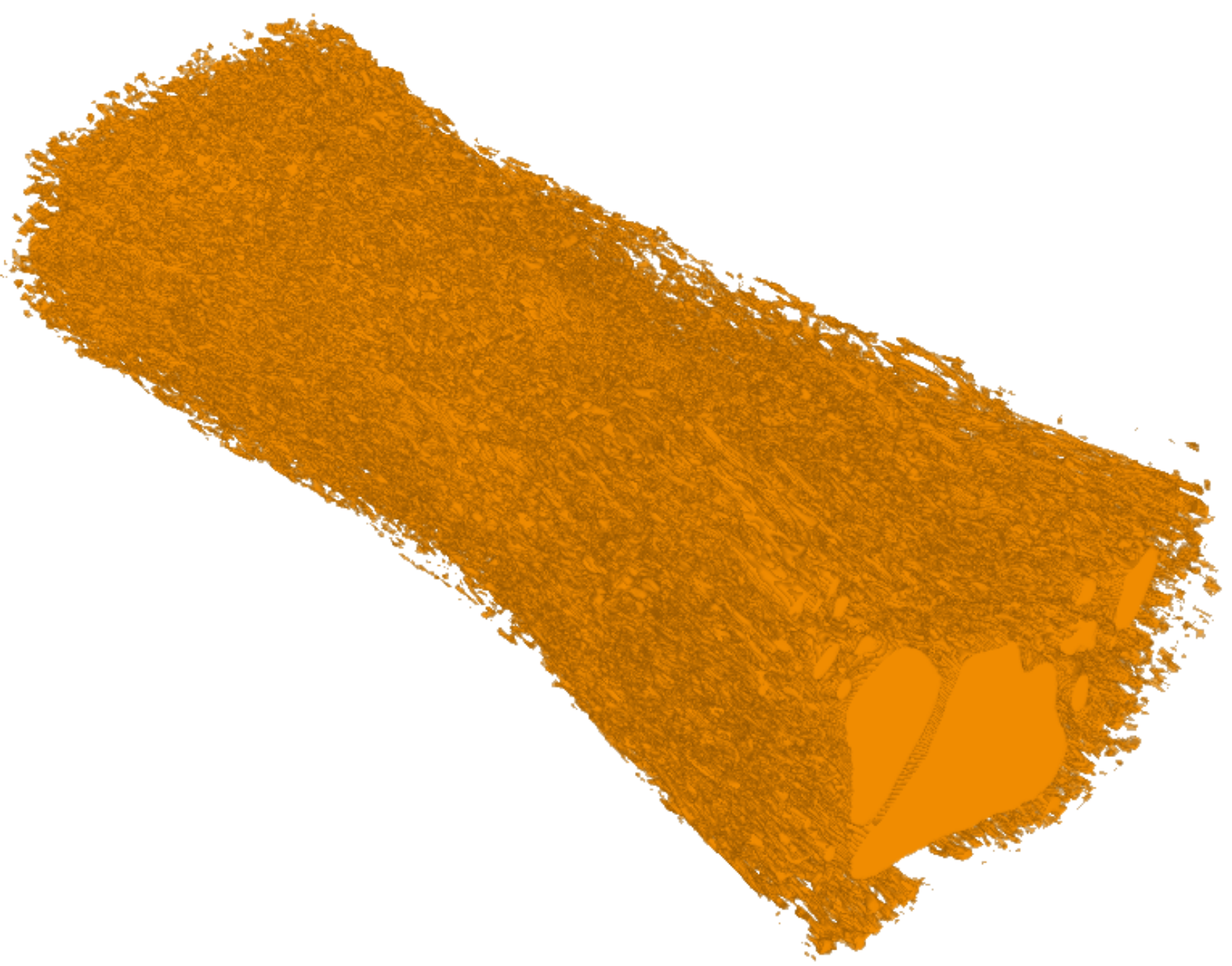

Figura 3.11 - Reconstrução 3D para rede de canais do osso 1.

Fonte: Elaborada pelo autor. 


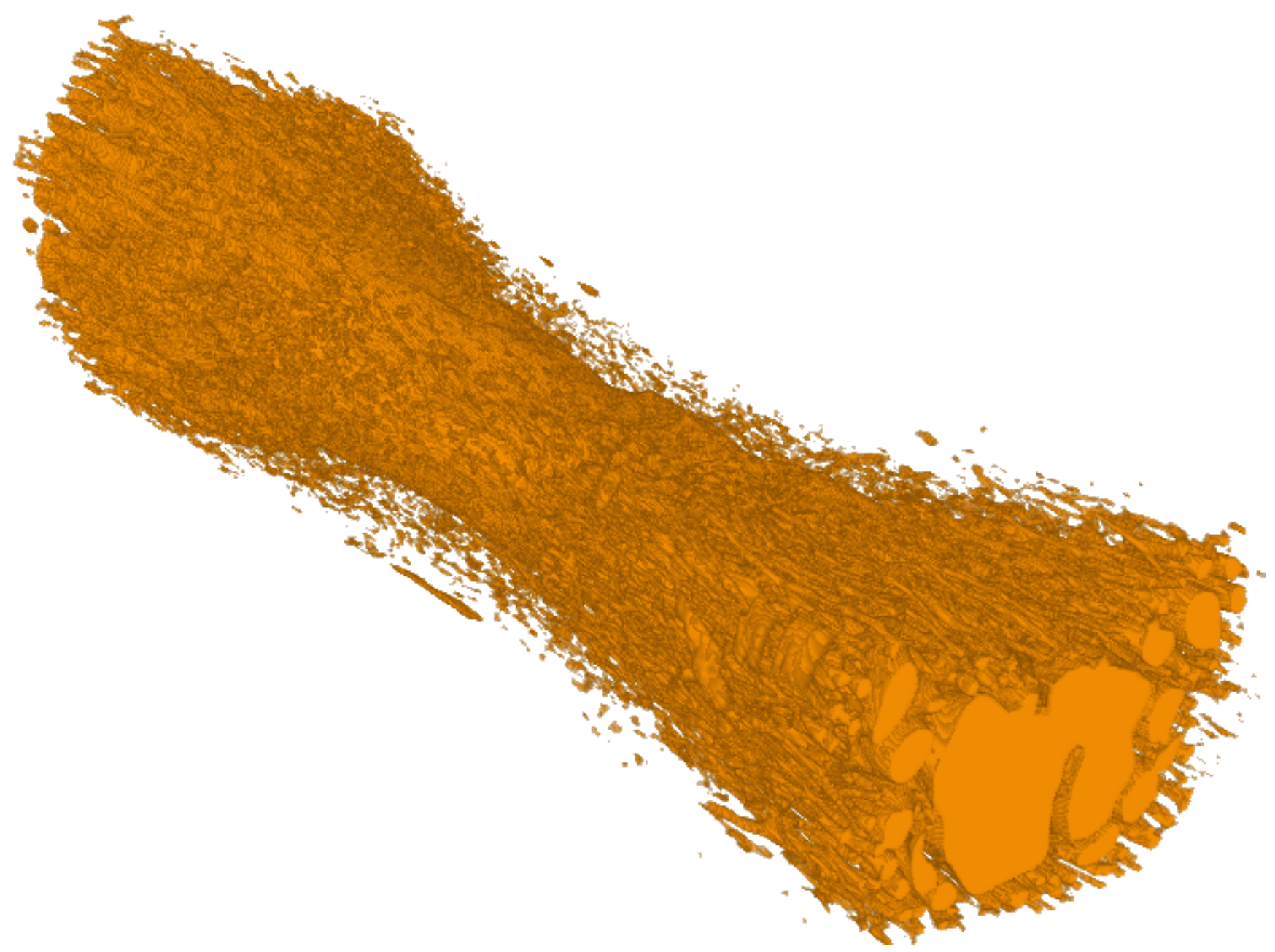

Figura 3.12 - Reconstrução 3D para a maior componente da rede 2.

Fonte: Elaborada pelo autor. 


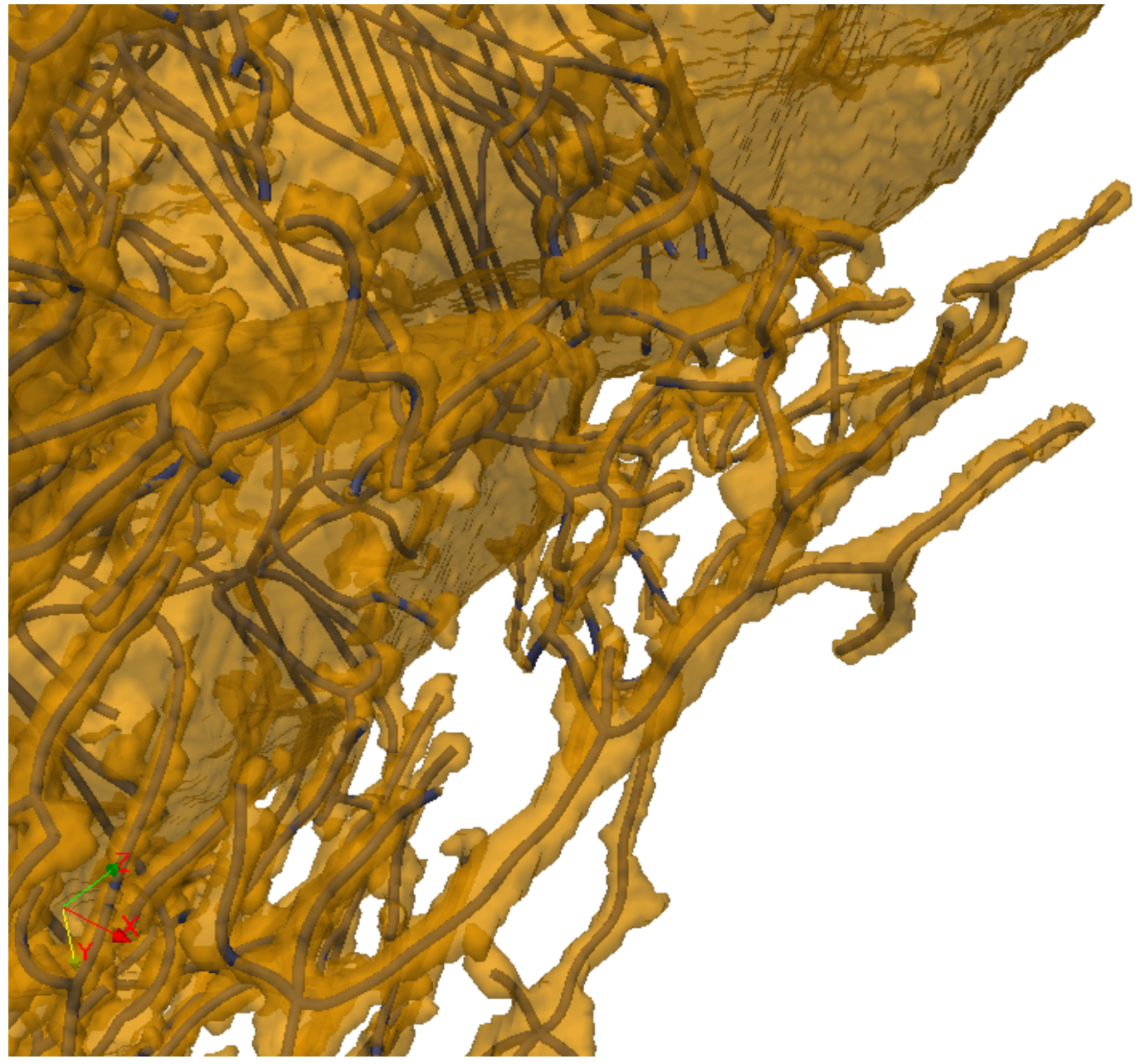

Figura 3.13 - Segmento do esqueleto (em azul) para a rede de canais (em amarelo) do osso 2.

Fonte: Elaborada pelo autor. 


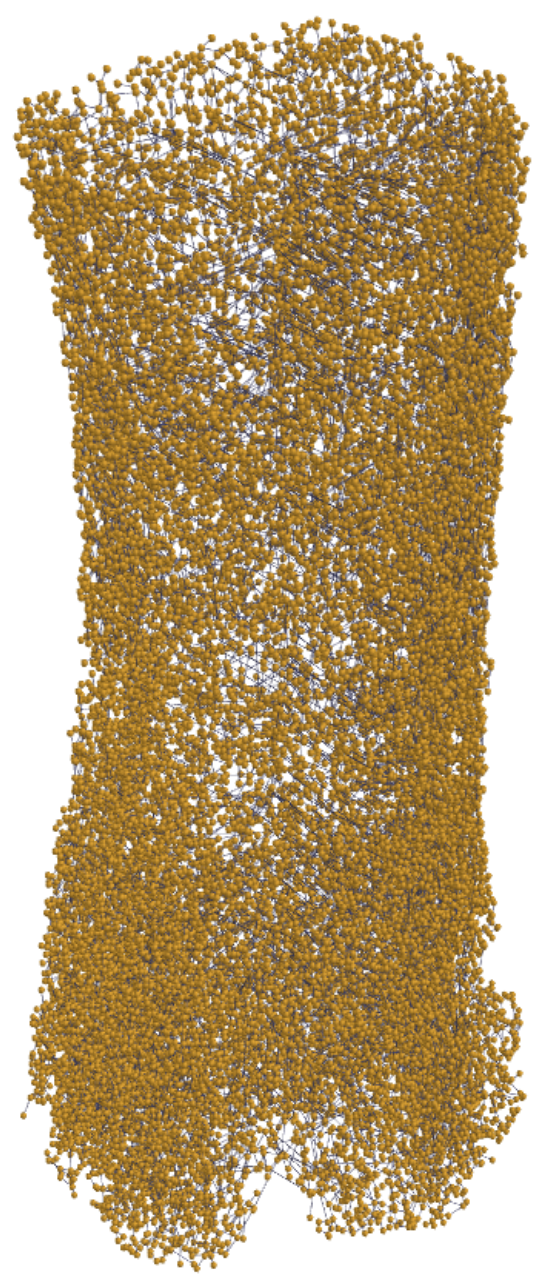

Figura 3.14 - Rede complexa para o osso 1.

Fonte: Elaborada pelo autor. 


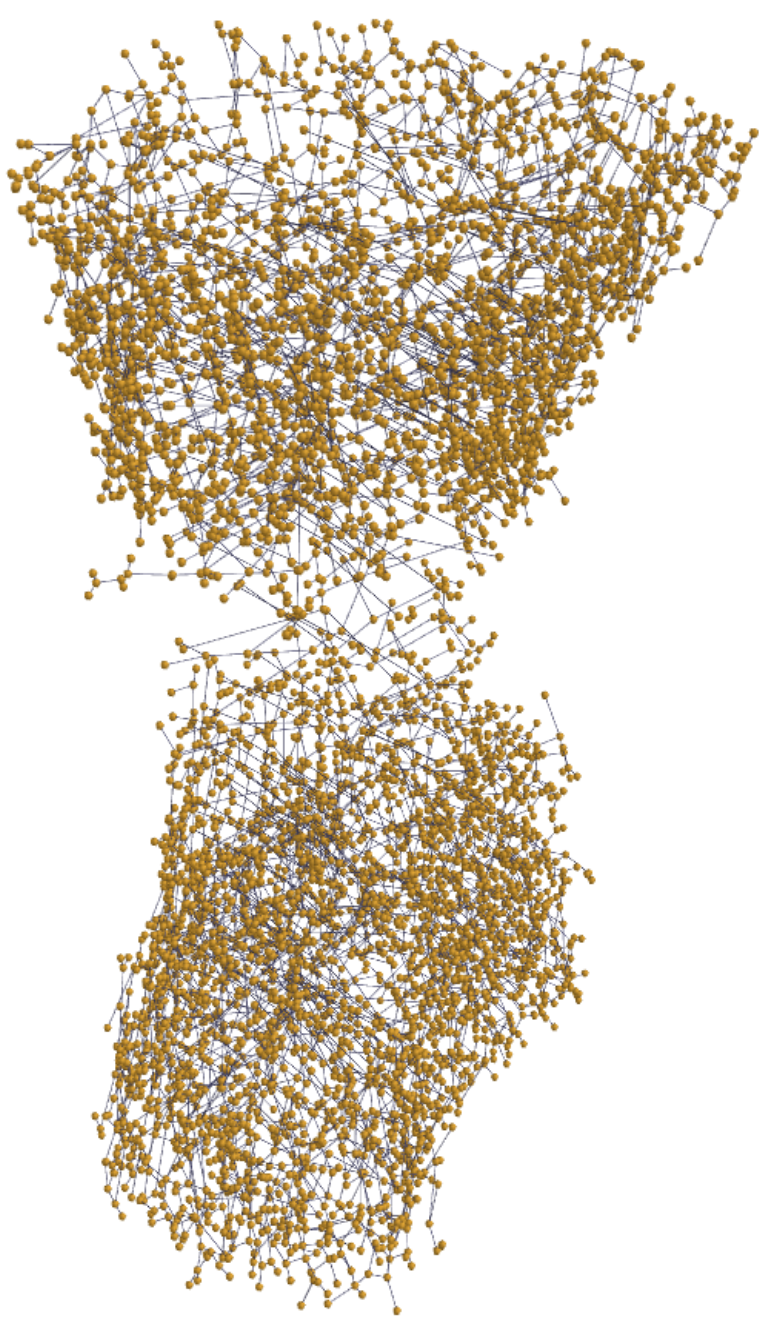

Figura 3.15 - Rede complexa para o osso 2.

Fonte: Elaborada pelo autor. 


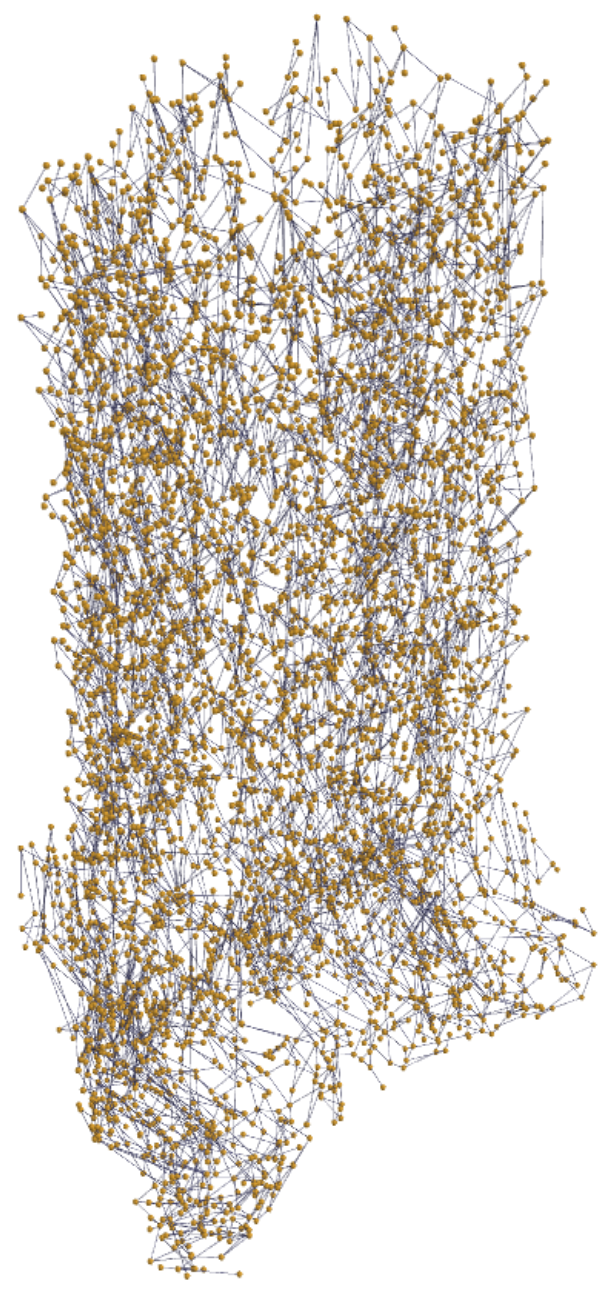

Figura 3.16 - Rede complexa do trabalho de Viana(1-3).

Fonte: Elaborada pelo autor. 


\subsection{Redes complexas}

Este capítulo apresenta os resultados para a análise das redes complexas em quatro áreas: valência dos vértices, robustez a ataques e falhas, posicionamento dos vértices, comunidades. A análise foi feita em Python (42) utilizando networkX (43), NumPy (44), matplotlib (45), MayaVi. (46)

A primeira rede deste relatório (composta por 25499 vértices e 36147 arestas) está representada em azul, e a segunda rede está representada em verde (composta por 6251 vértices e 7678 arestas). Em vermelho está representada a rede do trabalho de Viana (contendo 4963 vértices e 5982 arestas, vide tabela 3.17 para resumo). Esse esquema de cor será mantido até o final do documento.

Tabela 3.17 - Resumo para o quantidade de vértices, quantidade de arestas e valência média de cada rede.

\begin{tabular}{l|ccc} 
& Vértices & Arestas & Valência média \\
\hline Rede 1 & 25371 & 35017 & 2,76 \\
Rede 2 & 6218 & 7545 & 2,43 \\
Rede Viana & 4963 & 5982 & 2,41
\end{tabular}

Fonte: Elaborada pelo autor.

Comparando a rede $1 \mathrm{com}$ a rede Viana podemos ver um maior número de vértices $(5,1 x)$ e arestas $(5.9 x)$ oriundos do processo automático de construção, porém ao mesmo tempo não vemos essa diferença entre a rede 2 e a rede Viana (embora a rede 2 tenha sido feita pelo mesmo processo automatizado da rede 1). De fato, essa diferença é devido aos parâmetros utilizados durante o processamento das imagens (tamanho da janela deslizante, limiar para o fator de forma, etc.), eles devem ser ajustados para cada rede. Ainda assim veremos posteriormente (seção 3.8) que a rede 2 apresenta uma maior precisão no posicionamento dos vértices. 
O comportamento esperado das redes aleatórias foi obtido da média de 500 redes diferentes, todas com o mesmo número de arestas e vértices que suas contrapartes biológicas. Note que por construção as redes de canais não apresentam vértices com valência nulo ou valência dois (vide seção 3.7), essa limitação não se aplica às redes aleatórias. Note também que a rede 2 e a rede Viana possuem $|\vartheta|$ e $|\varepsilon|$ muito próximos quando comparadas à rede 1 , dessa forma 0 comportamento para a redes aleatórias originadas das rede 2 e rede Viana serão parecidos.

\subsection{Análise de valência}

A figura 3.18a mostra o histrograma normalizado para a valência das três redes de canais, e a figura $3.18 \mathrm{~b}$ apresenta o histograma para os análogos aleatórios. Podemos afirmar que para as redes biológicas os vértices com valência igual a um ou valência igual a três representam mais de $77 \%$ (na rede 1) e podem chegar a $87 \%$ (na rede 2), enquanto que o comportamento apresentado pela redes aleatórias mostra não mais do que $65 \%$ dos vértices com essas duas valências (vértices com de graus nulos e duais foram removidos). Note que se o vértices com valência 0 e 2 não fossem removidas a parcela seria ainda menor para as redes aleatórias, isso demonstra uma preferência por ramificações dicotômicas (em Y), esta tendência dicotômica é um fato conhecido em vascularização de órgãos e tecidos. Além disso para as redes de canais o decaimento é exponencial após o terceiro valência e por volta do quinto valência menos que $5 \%$ da rede está presente. 


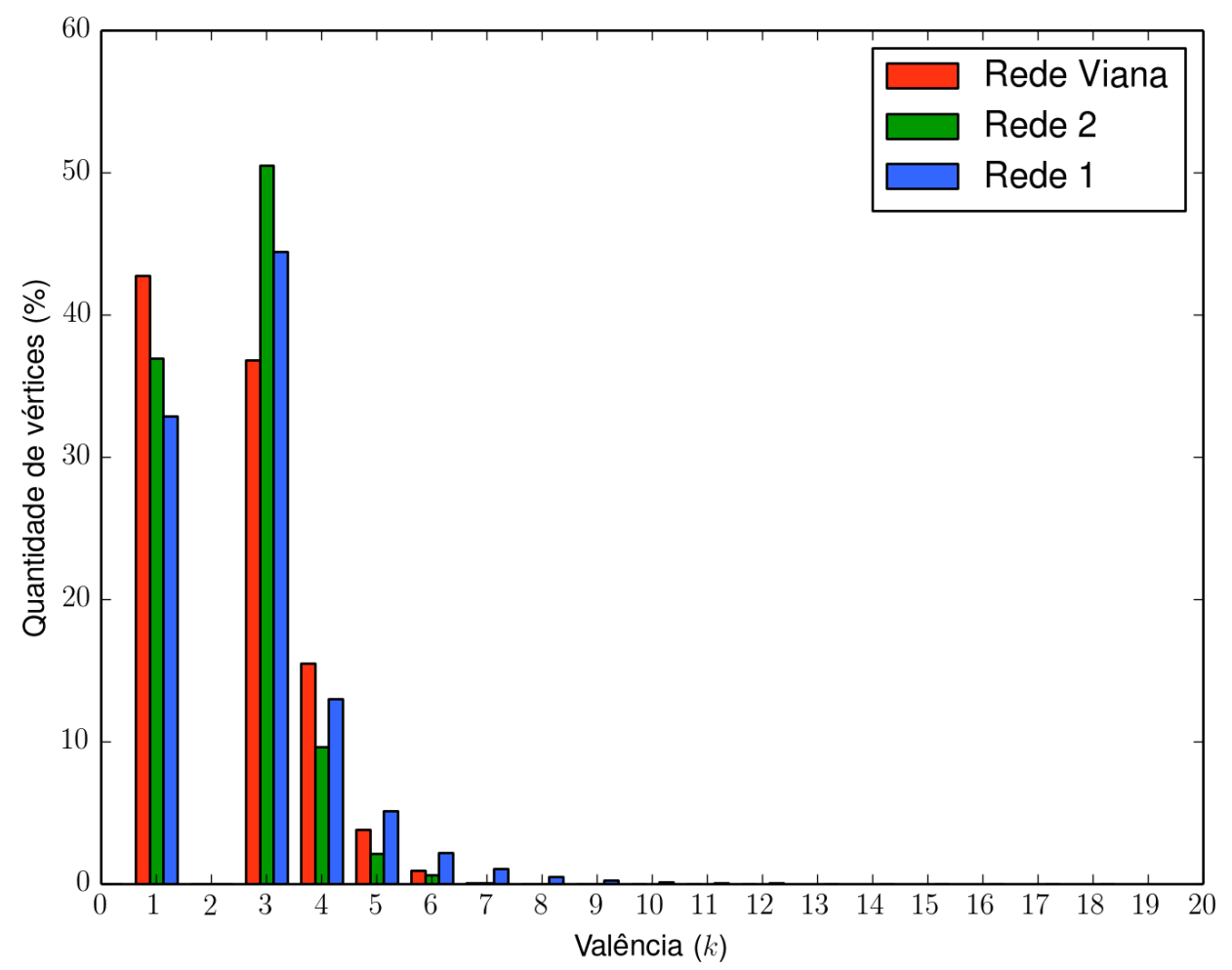

(a) Redes de canais

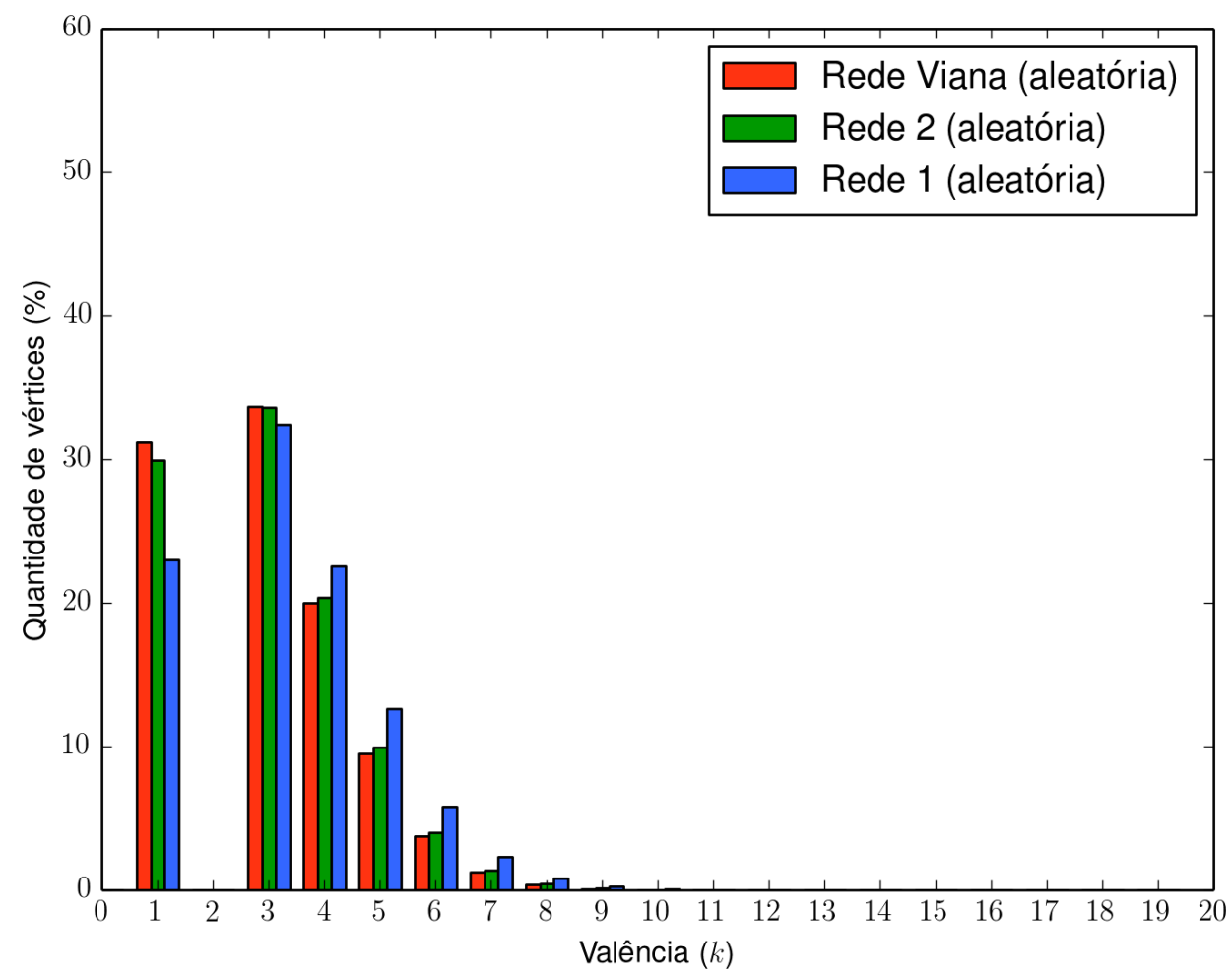

(b) Redes aleatórias

Figura 3.18 - Histograma de valência para as três redes. No eixo das abscissas temos o valência dos vértice e no eixo das ordenadas temos a porcentagem de vértices com determinado valência.

Fonte: Elaborada pelo autor. 


\subsection{Posicionamento dos vértices}

As próximas páginas apresentam os histogramas para o posicionamento dos vértices na rede. Os histogramas são divididos em cem classes e são normalizados pelo número total de vértices (somatória de todas as classes tem valor 1). As figuras também incluem os histogramas para a quantidade de arestas apresentadas por cada vértice (neste caso os histogramas são normalizados pelo núemro total de arestas) e o resulatado para as respectivas redes aleatórias. As redes aleatórias tiveram uma posição atribuida para cada nó seguindo uma distribuição uniforme em coordenadas cartesianas $(x, y, z)$.

O sistema de coordenada utilizados é o cilíndrico com a origem localizado no centro da parte inferior das redes. Para que os gráficos fossem comparavéis as coordenadas $\rho$ e $z$ foram redimensionadas para o intervalo $[0,1]$, a coordenada $\theta$ utiliza o intervalo $\left[0^{\circ}, 360^{\circ}\right.$, seguem as seguintes observações:

- Para a coordenada $\rho$ (figuras 3.19, 3.20 e 3.21), a região de maior concentração de vértices acontece em um anel entre $45 \%$ e $60 \%$ do raio da rede, de fato, quando comparadas com a redes aleatórias vemos uma clara preferência por essa região em relação principalmente ao periferia da rede. Note entretanto que o canal central possui um diametro muito maior que os canais periféricos, logo canais centrais deveriam apresentar um peso maior no histograma (visto que canais mais largos podem apresentar um fluxo maior de sangue). Esta dicussão já foi abordada na seção 3.5 e é um aprimoramento do modelo.

- Em $\theta$ (figuras 3.22, 3.23 e 3.24), os ossos foram rotacionados de forma que a face posterior fique pra baixo e a face ântero medial pra cima. Nota-se uma maior concentração de vértices na região entre $190^{\circ}$ e $225^{\circ}$ e na região entre $320^{\circ}$ e $345^{\circ}$ (novamente um comportamento divergente do aleatório). 
- Para $z$ (figuras 3.25, 3.26 e 3.27), o comporatamento das redes se mostra divergente. Para a rede Viana vemos várias regiões sem nenhum vértice e algumas poucas regiões com uma grande quantidade de vértices (provavelmente o processo semi automatizado não possui precisão suficiente para definirmos as posições em $z$ ). Para a rede 2 temos todos as classes do histograma ocupadas com excessão de uma região central onde há uma ausencia total de vértices. Para a rede 1 temos uma distribuição quase uniforme, podemos dizer que há uma leve ausencia de vértices no meio do osso (como na rede 2 porém bem menos intensa) e uma leve preferencia pela parte inferior do osso (de $0 \%$ até $30 \%$ da altura).

- A distribuição de vértices e arestas apresentam o mesmo perfil, ou seja, não há nenhuma região privilegiada do osso onde há uma maior concentração de canais. 


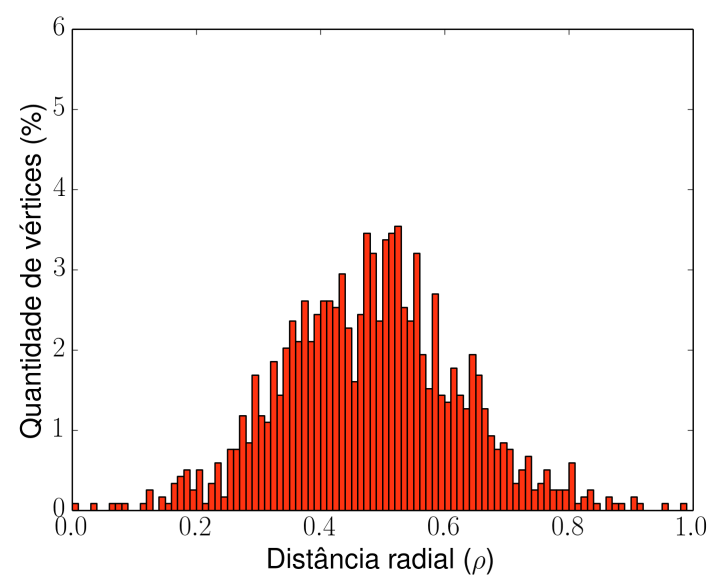

(a) Vértices

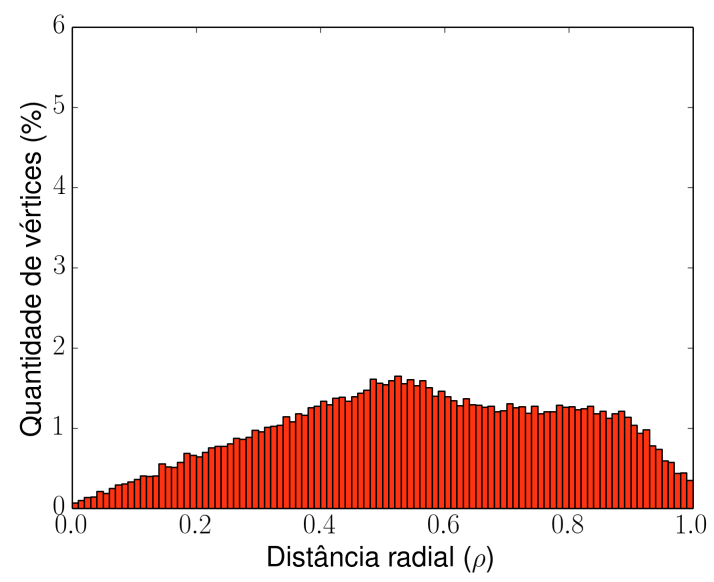

(c) Vértices aleatórios

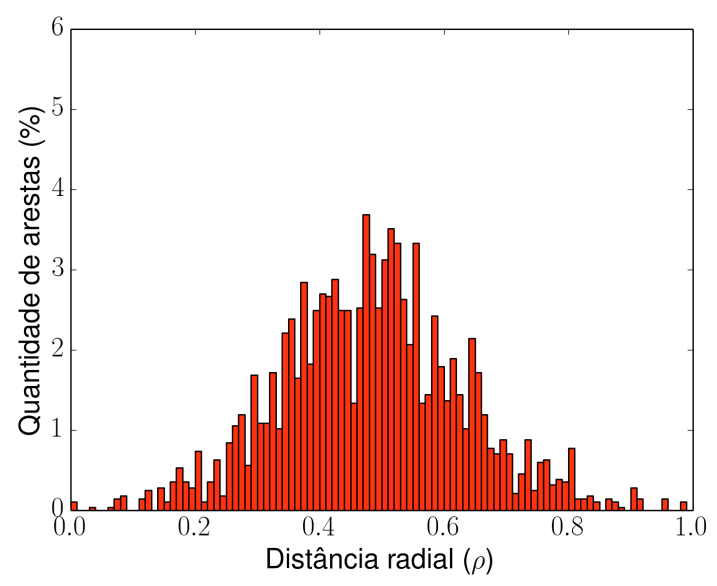

(b) Arestas

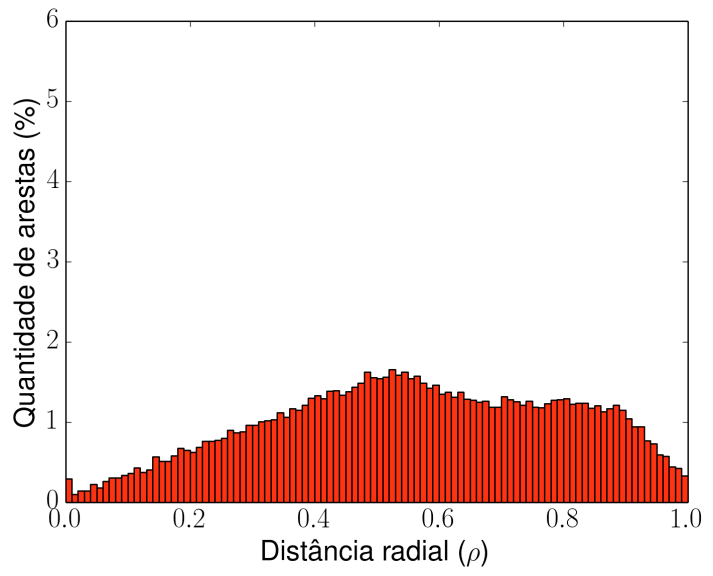

(d) Arestas aleatórios

Figura 3.19 - Distribuição ao longo do eixo radial para a rede Viana $($ a $)$ e (b) e para o análogo aleatório (c) $e(d)$.

Fonte: Elaborada pelo autor. 


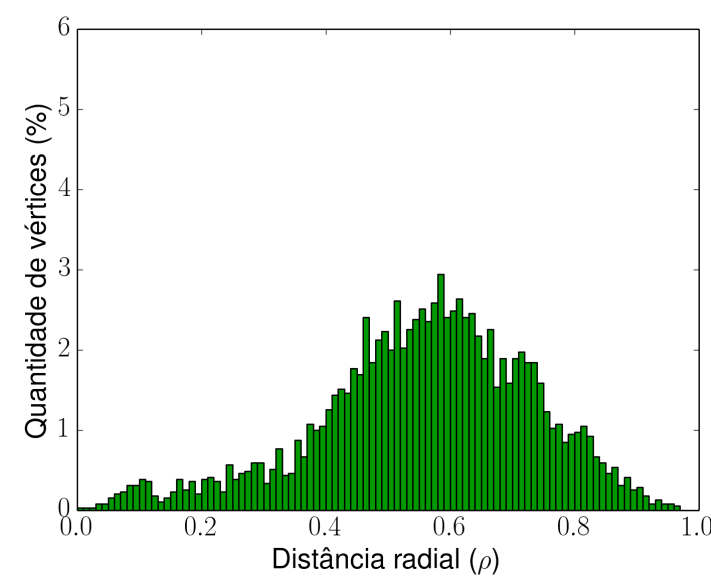

(a)

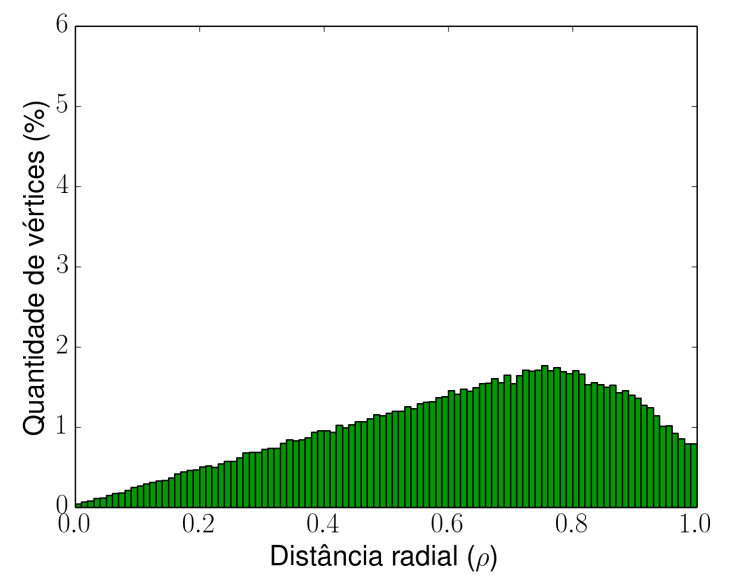

(c)

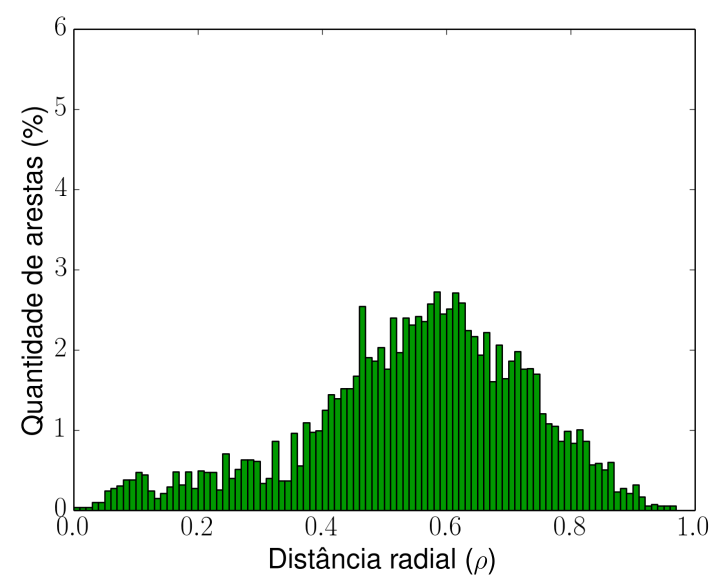

(b)

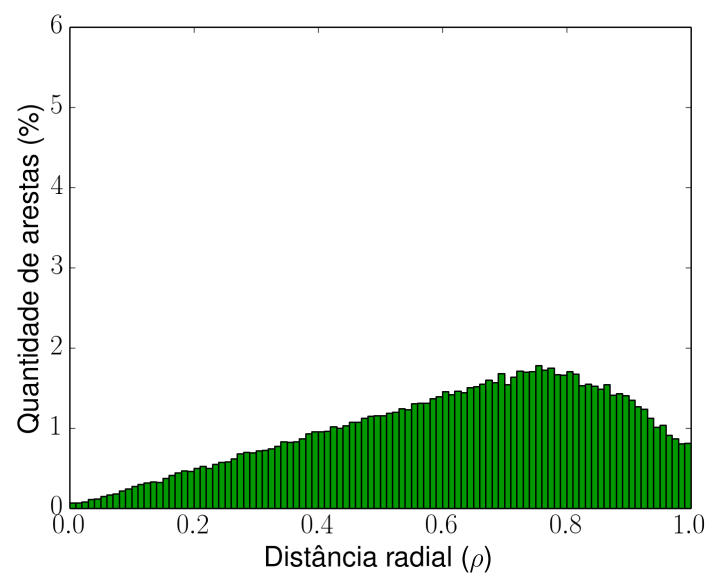

(d)

Figura 3.20 - Distribuição ao longo do eixo radial para a rede 2 (a) e (b) e para o análogo aleatório (c) $e(d)$.

Fonte: Elaborada pelo autor. 


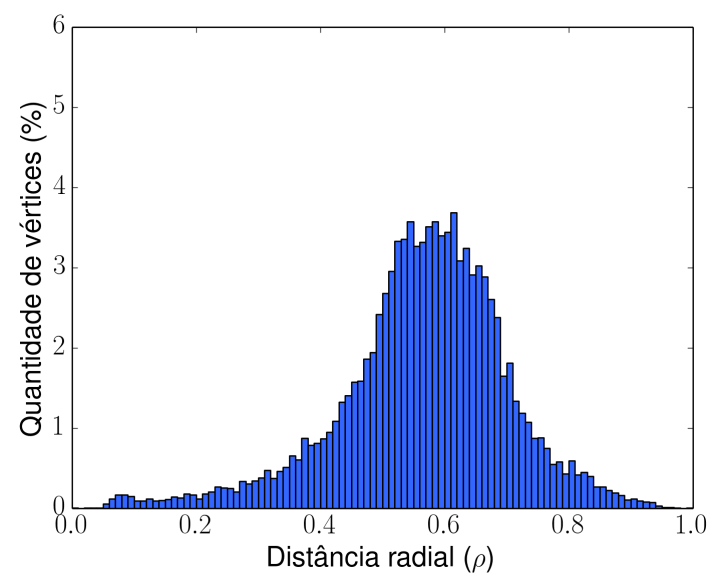

(a)

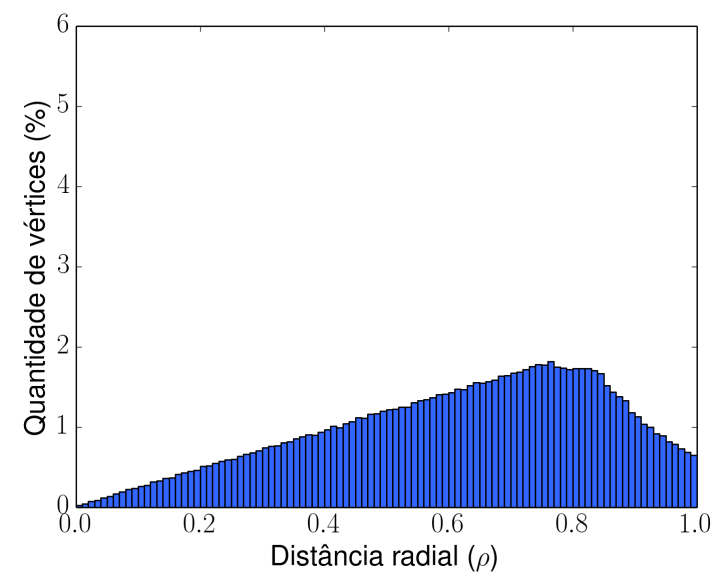

(c)

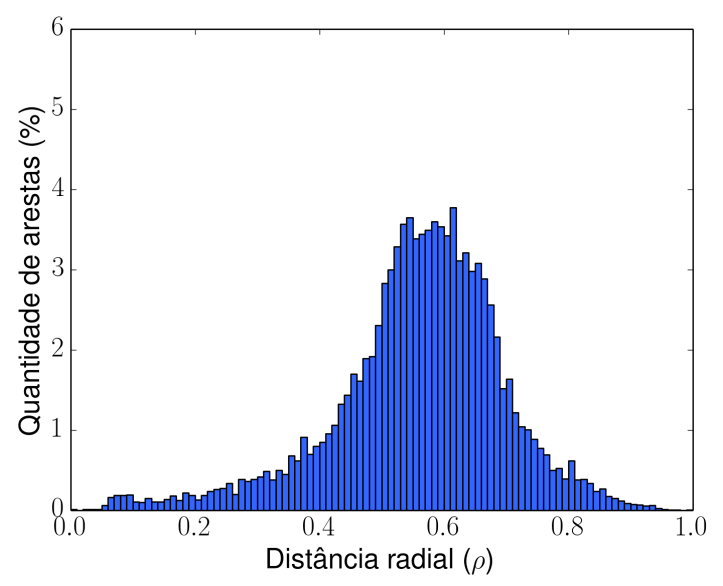

(b)

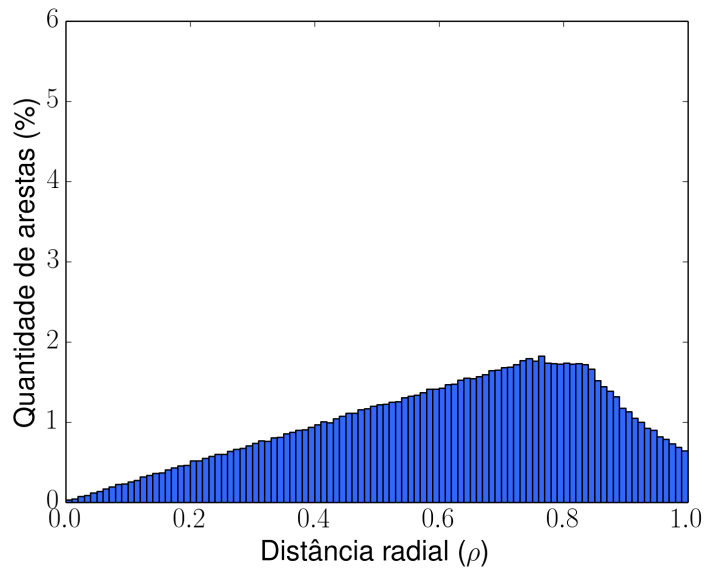

(d)

Figura 3.21 - Distribuição ao longo do eixo radial para a rede $1($ a) e (b) e para o análogo aleatório (c) $e(d)$.

Fonte: Elaborada pelo autor. 


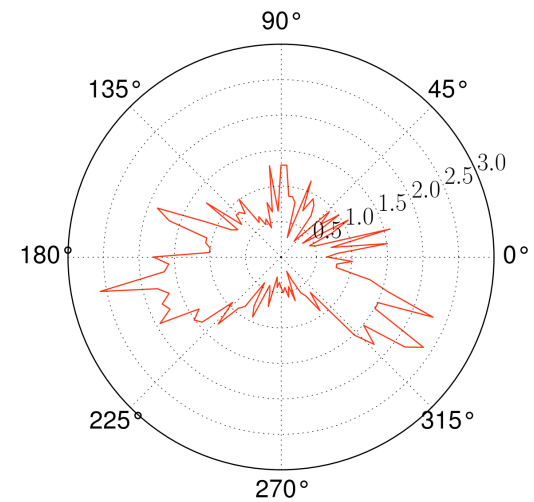

(a)

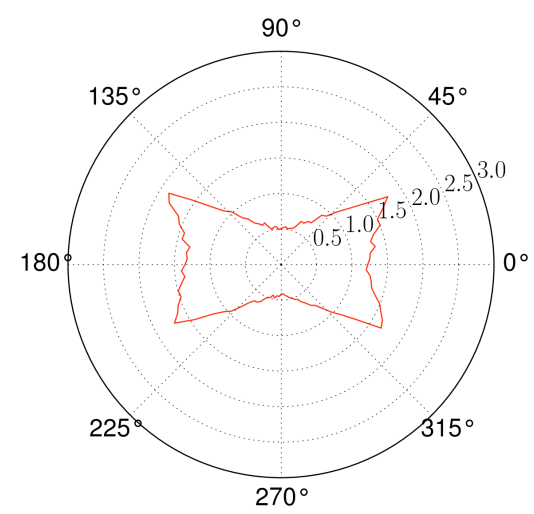

(c)

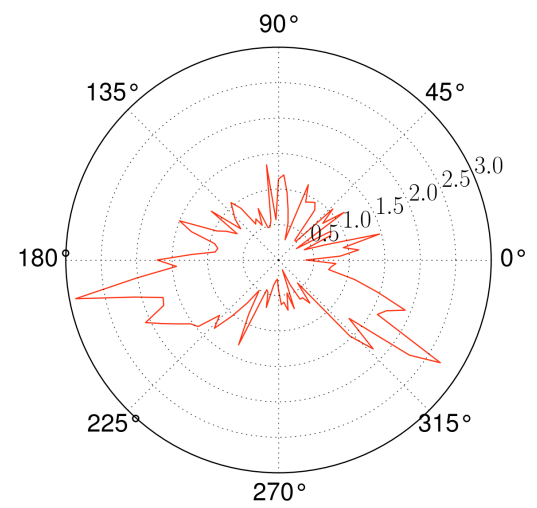

(b)

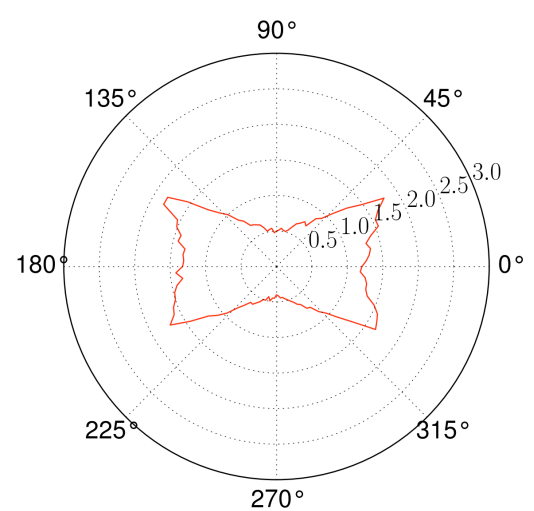

(d)

Figura 3.22 - Distribuição para o ângulo azimutal para a rede Viana $($ a $)$ e (b) e para o análogo aleatório (c) $e(d)$.

Fonte: Elaborada pelo autor. 


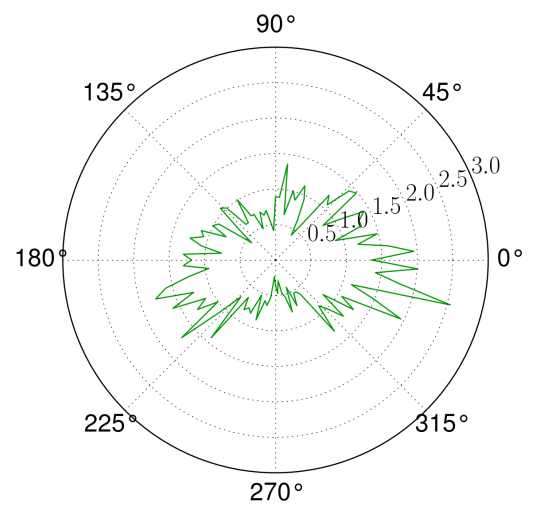

(a)

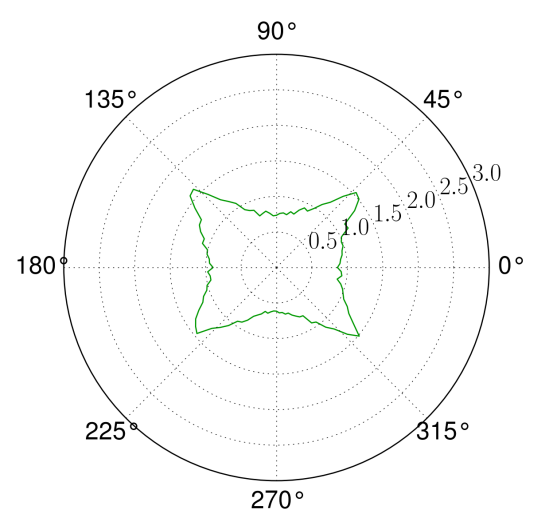

(c)

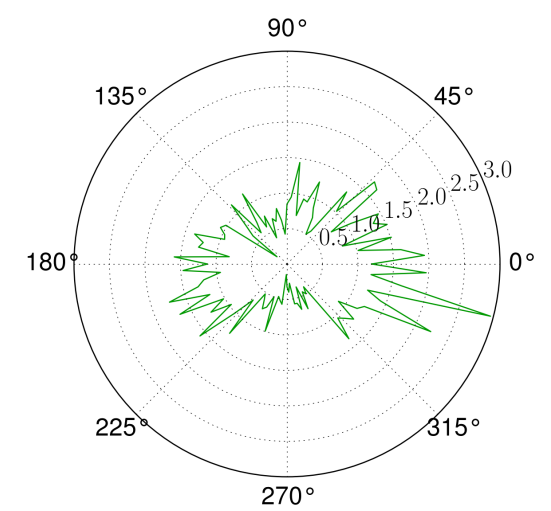

(b)

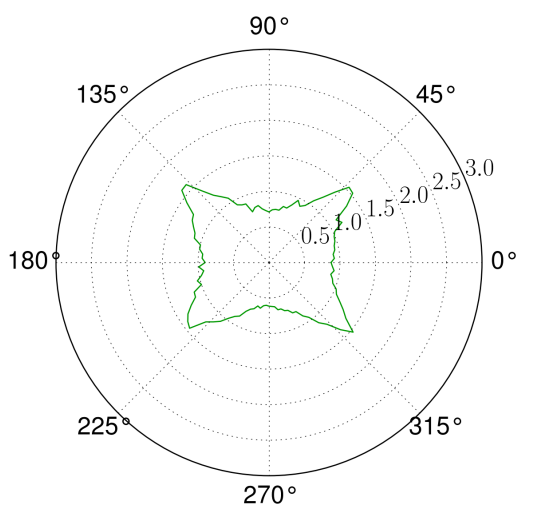

(d)

Figura 3.23 - Distribuição para o ângulo azimutal para a rede $1($ a $)$ e (b) e para o análogo aleatório (c) $e(d)$.

Fonte: Elaborada pelo autor. 


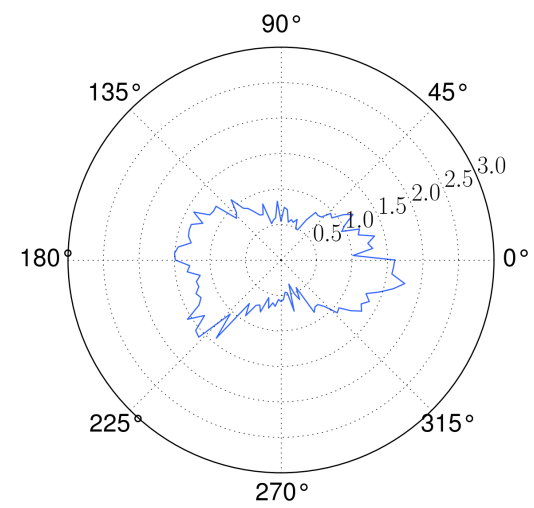

(a)

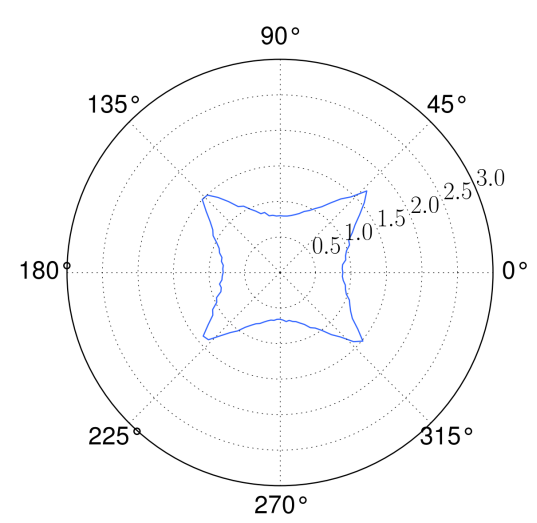

(c)

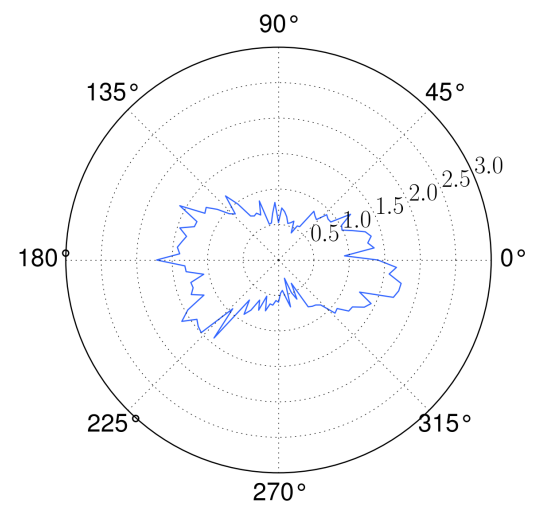

(b)

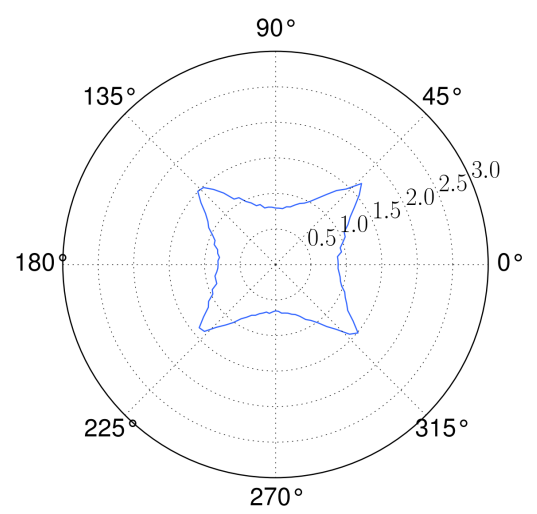

(d)

Figura 3.24 - Distribuição para o ângulo azimutal para a rede $2(a)$ e (b) e para o análogo aleatório (c) $e(d)$.

Fonte: Elaborada pelo autor. 


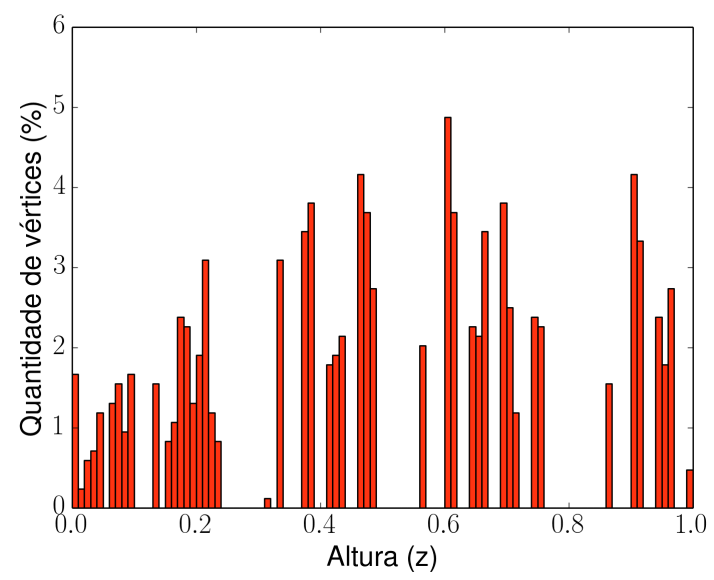

(a)

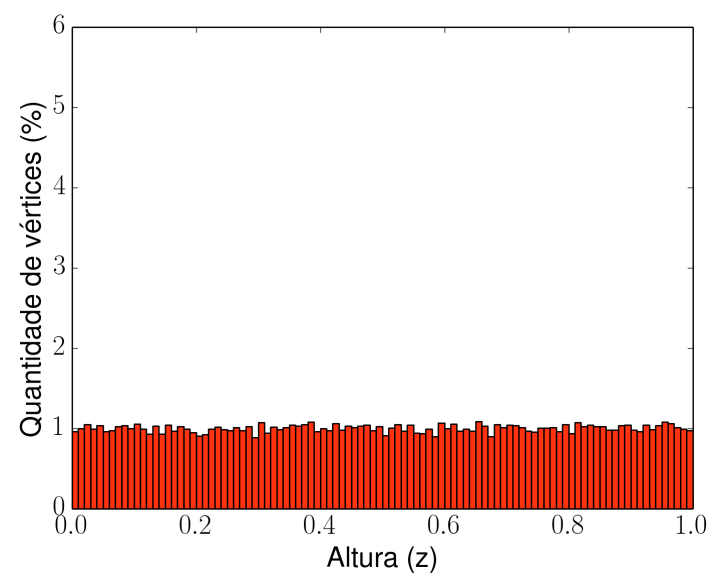

(c)

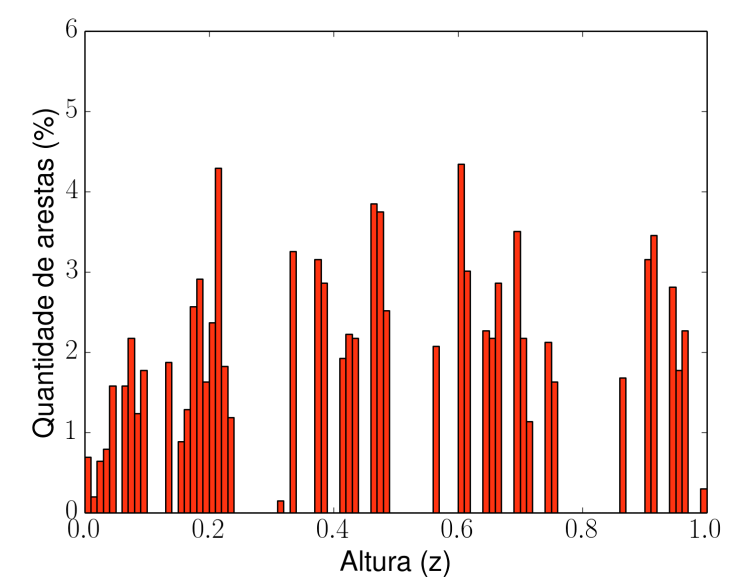

(b)

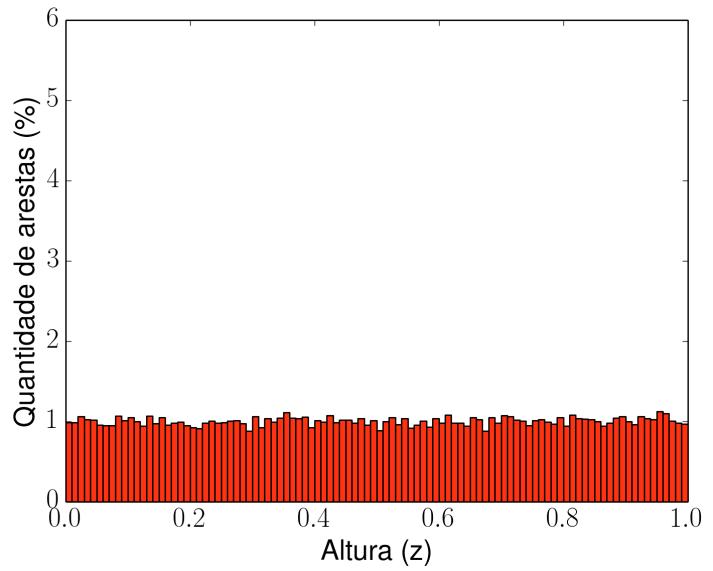

(d)

Figura 3.25 - Distribuição ao longo do eixo longitudinal para a rede Viana $(a)$ e (b) e para o análogo aleatório $(c) e(d)$.

Fonte: Elaborada pelo autor. 


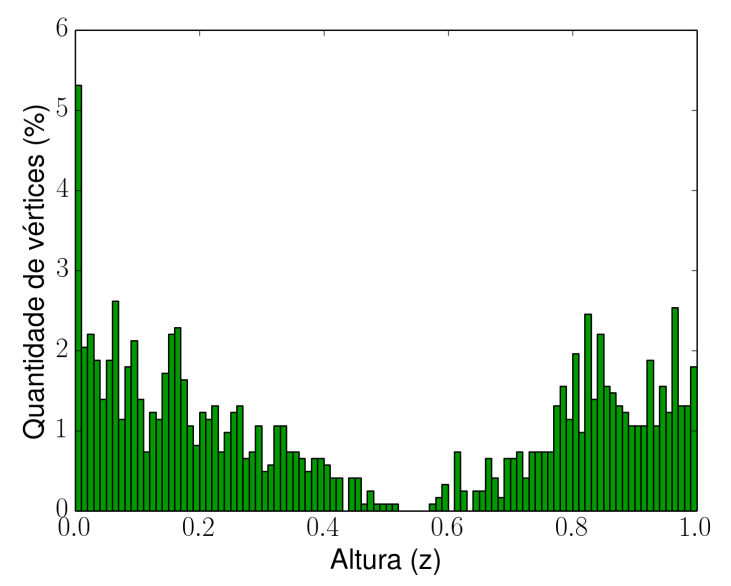

(a)

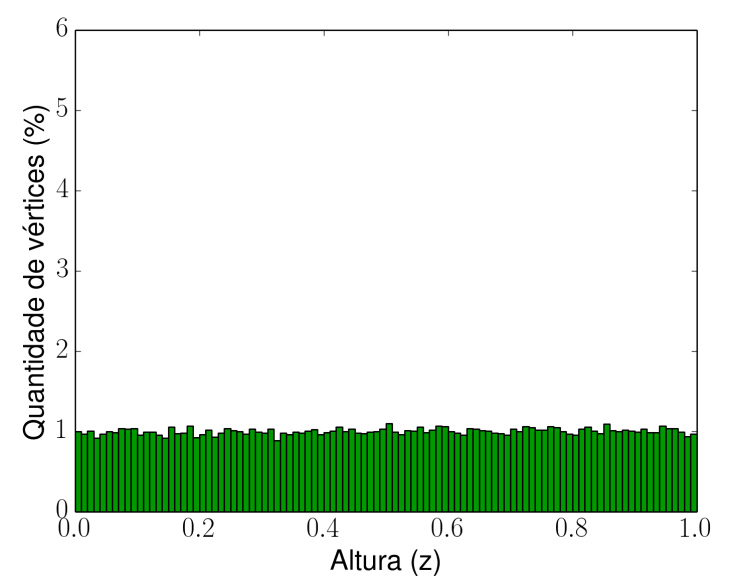

(c)

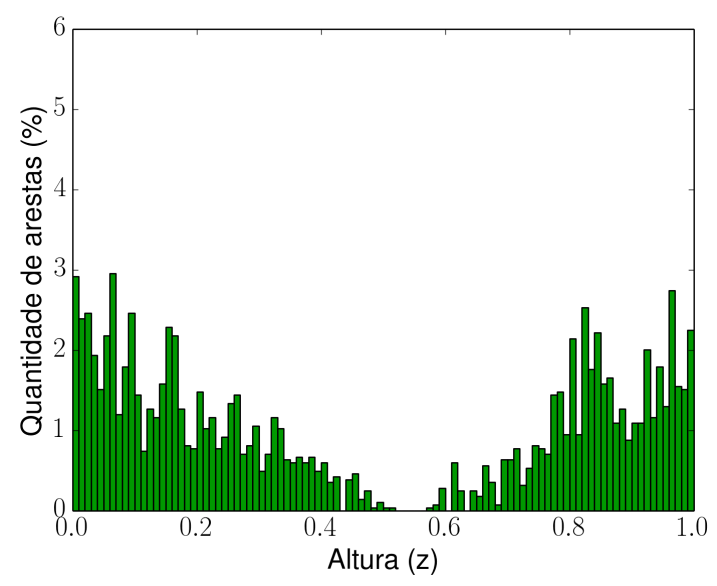

(b)

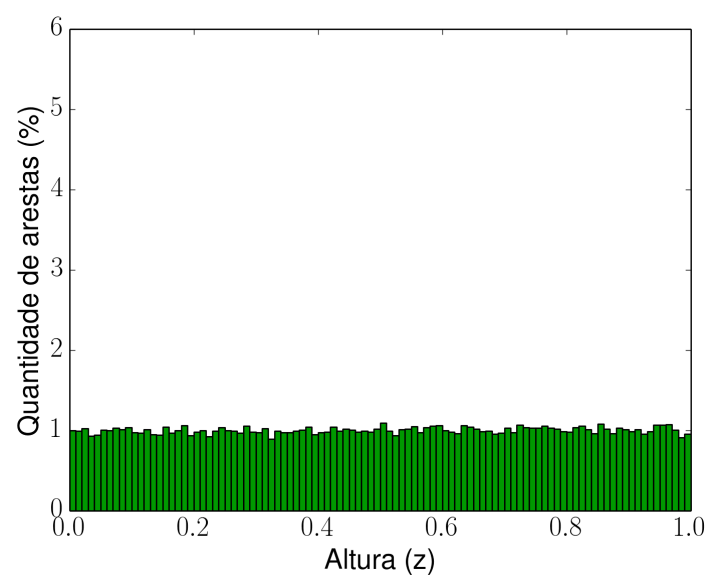

(d)

Figura 3.26 - Distribuição ao longo do eixo longitudinal para a rede $2(a)$ e (b) e para o análogo aleatório $(c) e(d)$.

Fonte: Elaborada pelo autor. 


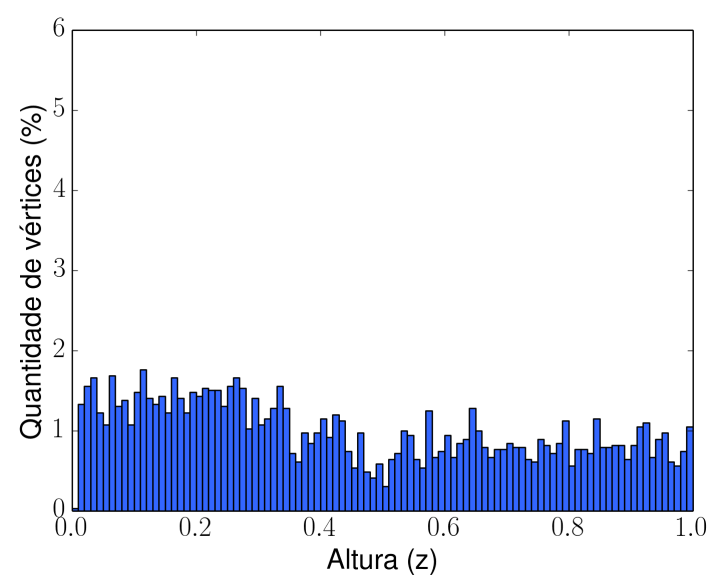

(a)

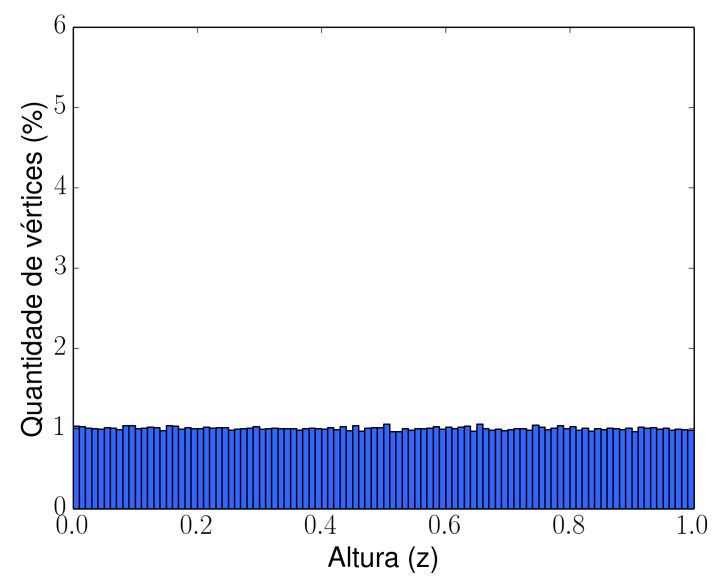

(c)

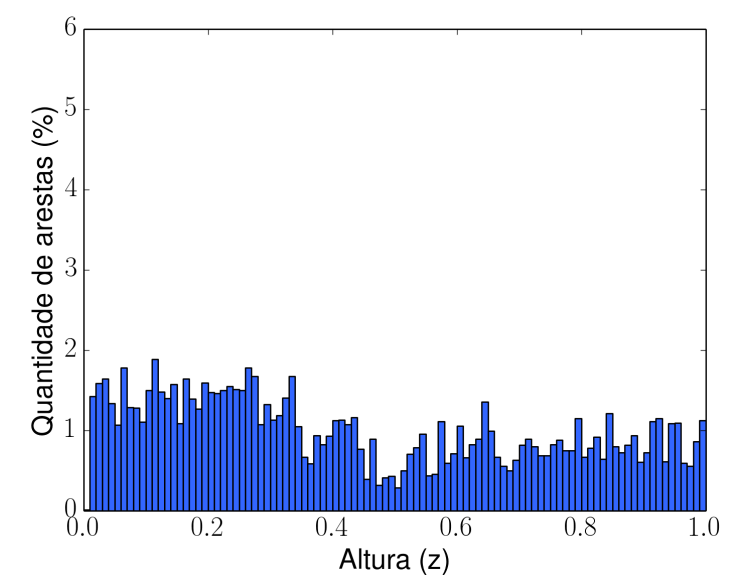

(b)

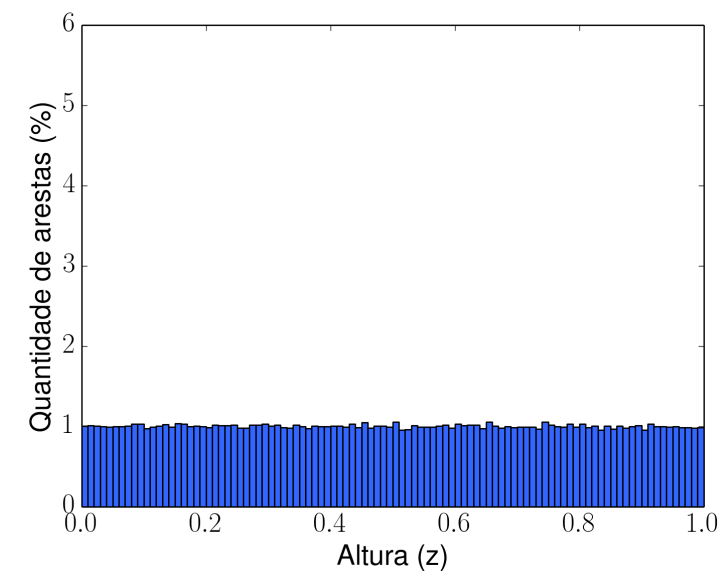

(d)

Figura 3.27 - Distribuição ao longo do eixo longitudinal para a rede 1 (a) e (b) e para o análogo aleatório $(c) e(d)$.

Fonte: Elaborada pelo autor. 


\subsection{Ataques}

Realizamos sobre as redes um conjunto de ataques aleatórios (falhas) e um conjunto de ataques sistemáticos em cascata como definidos em Crucitti et al. (47) O modelo em cascata consiste em escolhermos aleatóriamente um nó incial e remove-lo, em seguida removemos seus vizinhos, e depois os vizinhos dos seus vizinhos, e asim sucessivamente. Utilizaremos como medida de robustez o número de vértices e o número de arestas da maior componente da rede (vide figura 3.30 para as falhas e a figura 3.32 para os ataques em cascata). Para os ataques em cascata, também utilizamos como medida de robustez o fluxo máximo entre o vértice com maior valor de $z$ e o vértice com menor valor de $z$ (fig. 3.33). Os ataques serão realizados até que as redes sejam completamente destruidas.

Em seguida realizamos os mesmos ataques porém removendo arestas em vez de vértices (figura 3.31), note entretanto que não temos uma definição para vizinhos de uma aresta logo não podemos realizar ataques em cascata neste caso. Em todos os casos os resultados foram comparados com redes aleatórias (para calcular de fluxo máximo das redes aleatórias seus vértices tiveram posições geradas aleatóriamentes como na seção anterior). Note que a remoção de um vértice ou aresta pode gerar vértices com valência $k=0$ ou $k=2$, entretanto como já discutido na seçã̃ 3.5 esses dois casos não são válidos. Desse modo verificamos por esses casos depois de cada ataque; os vértices com $k=0$ são removidos (vide figura 3.28) e os vértices com $k=2$ são substituidos por uma aresta ligando seus dois vizinhos (vide figura 3.29).

Para as falhas as redes de canais apresentam robustez ligeiramente menor (até 20\%) que a apresentada pelas redes aleatórias. Para ataques em cascata, a robustes das redes de canais é de quatro a cinco vezes maior que as redes aleatórias, note também que o número total de ataques necessários para aniquilar as três redes é aproximadamente o mesmo apesar de a rede 1 ser aproximadamente conco vezes maior que as outras duas. 


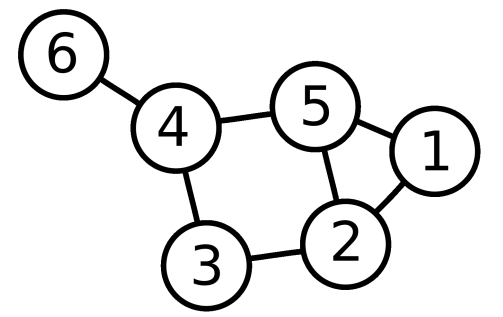

(a)
(6)

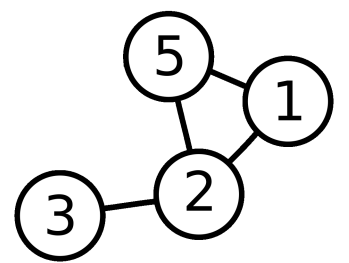

(b)

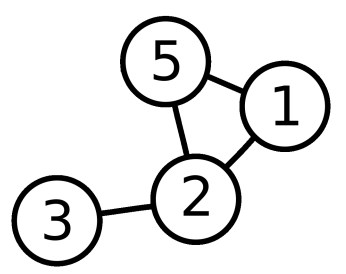

(c)

Figura 3.28 - Durante o processo de ataques alguns vértices podem tornar-se isolados. O exemplo abaixo apresenta uma rede (a) que tem o vértice 4 removido deixando o vértice 6 sem vizinhos (b). Neste caso os vértices isolados são removidos do grafo (c)

Fonte: Elaborada pelo autor.

6

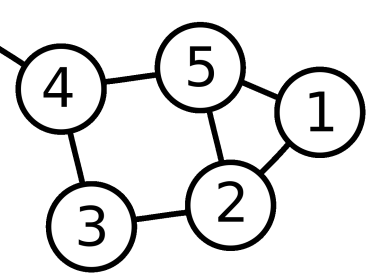

(a)

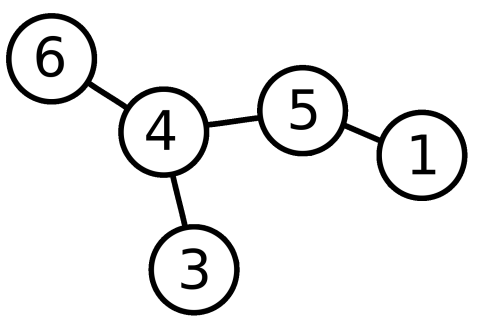

(b)

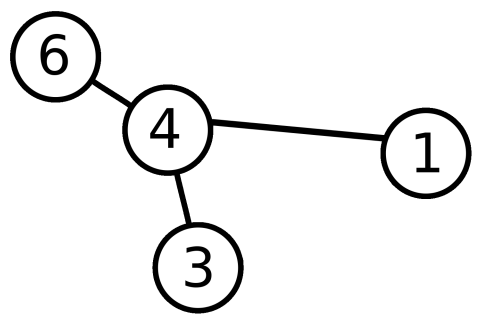

(c)

Figura 3.29 - A remoção de vértices da rede pode acarretar em alguns vértices com $k=2$. Como já discutido na seção 3.5 este caso não é válido. No exemplo abaixo o vértice 2 é removido da rede original (a) deixando o vértice 5 com apenas dois vizinhos (b). Note que para a rede de canais essa situação é análoga a uma ligação direta entre o vértice 1 e o vértice 4 (c).

Fonte: Elaborada pelo autor. 


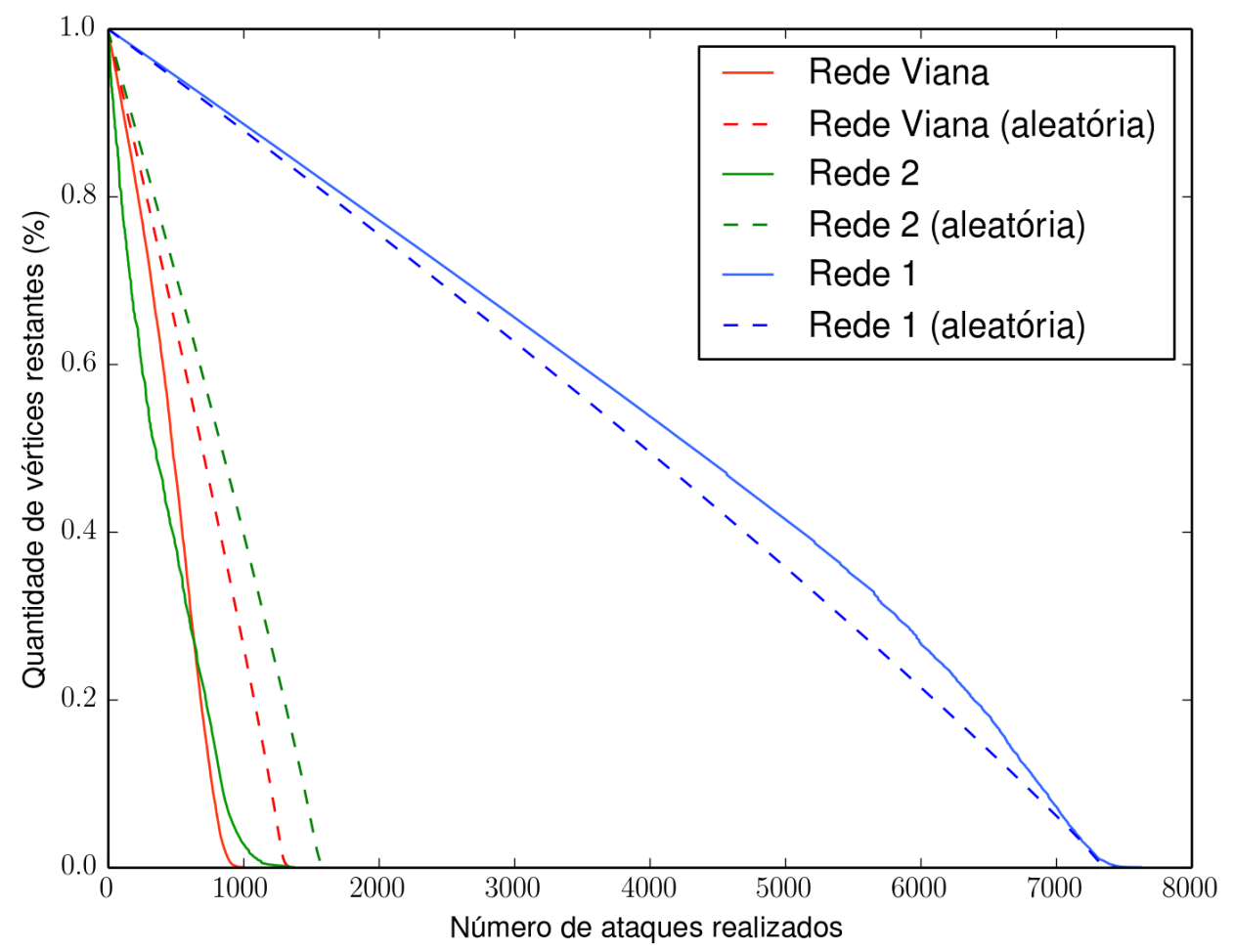

(a)

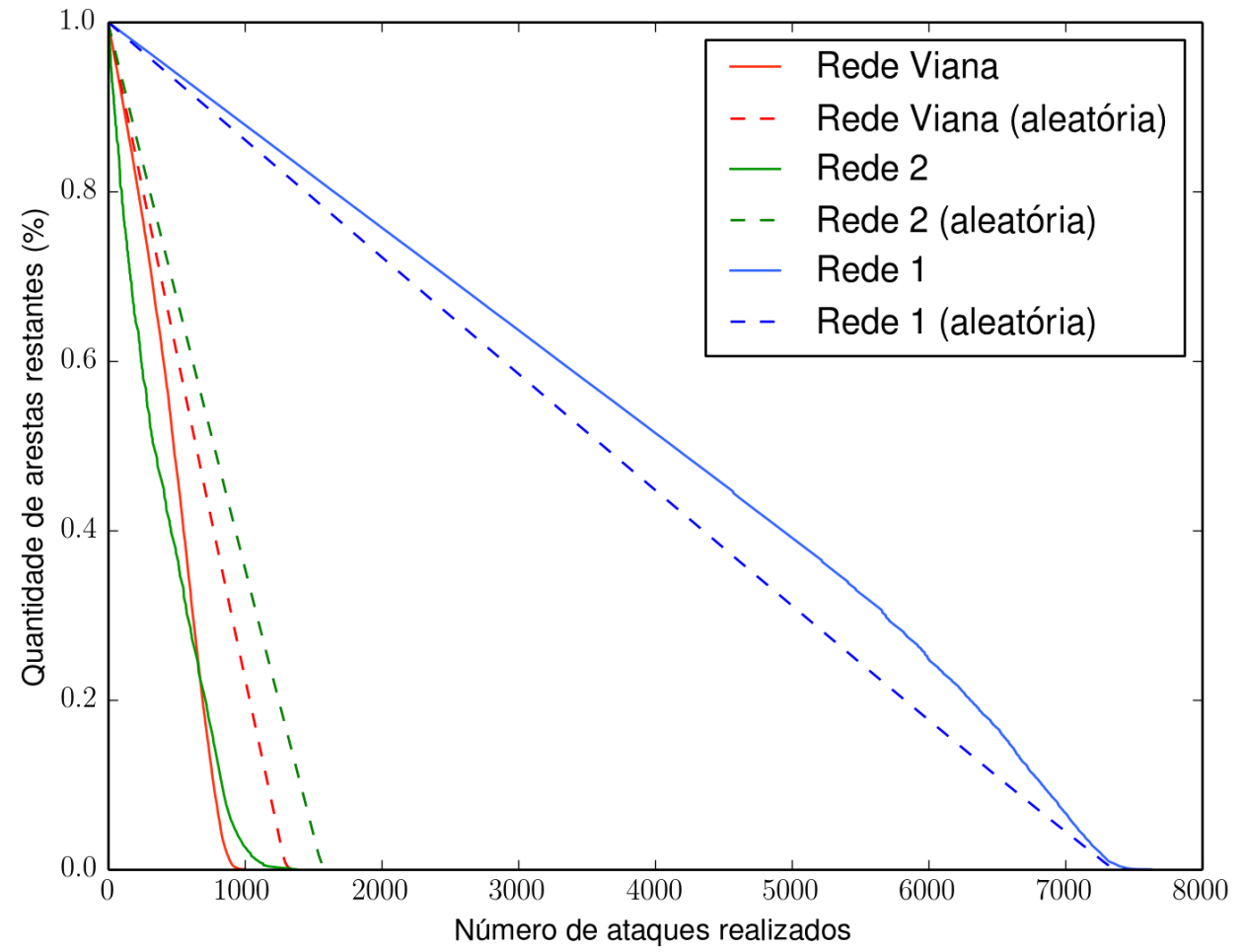

(b)

Figura 3.30 - Falhas em vértices.

Fonte: Elaborada pelo autor. 


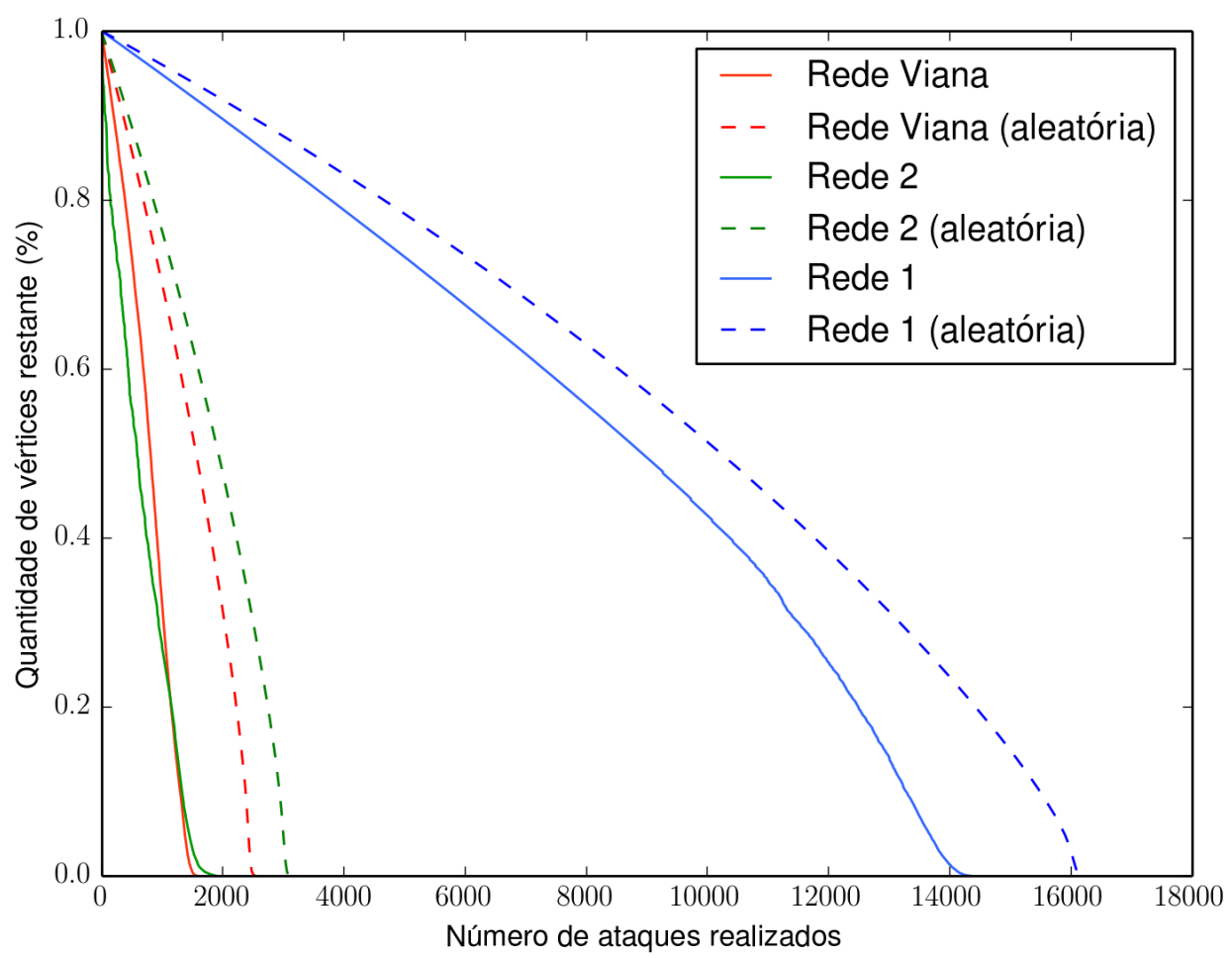

(a)

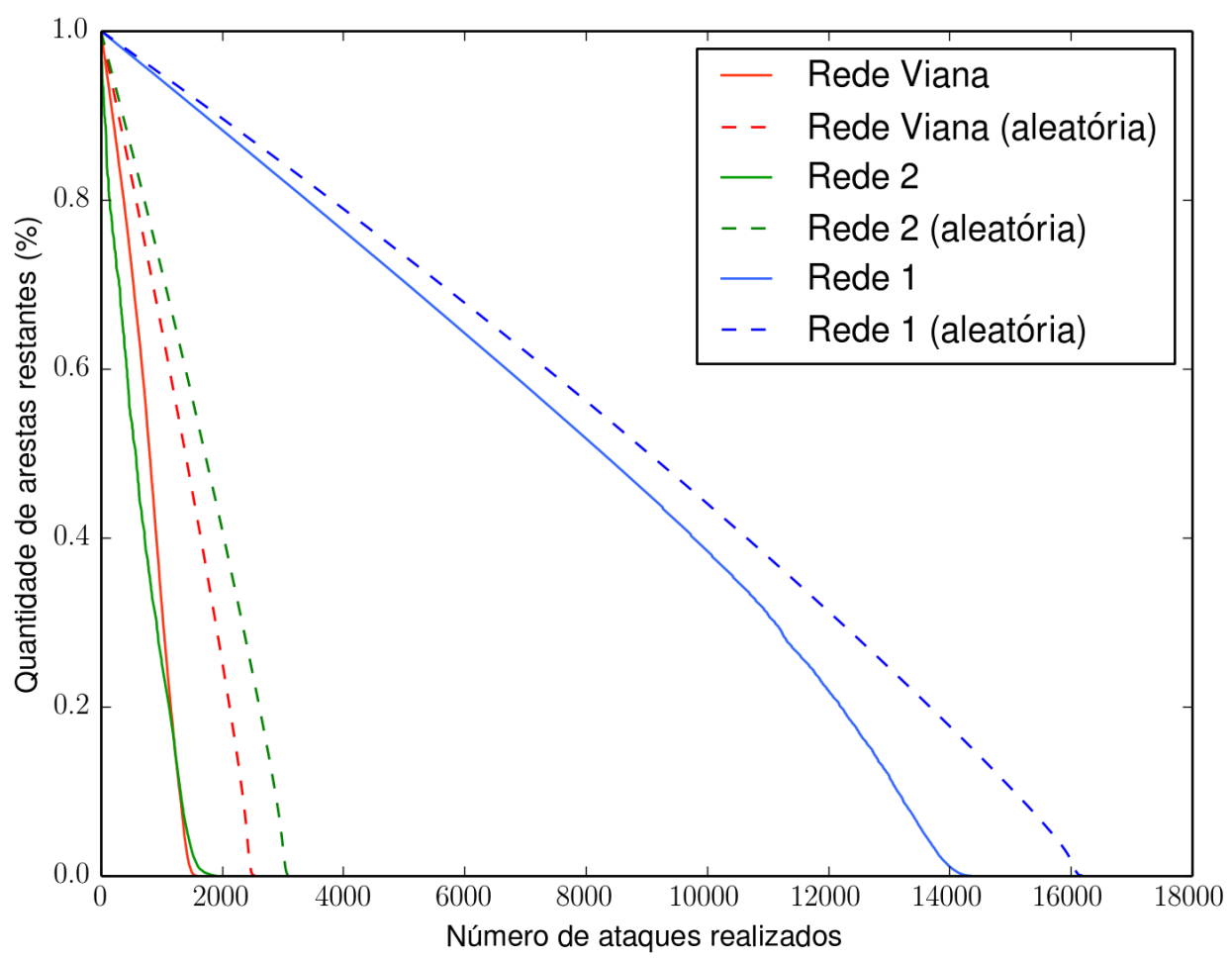

(b)

Figura 3.31 - Falhas em arestas.

Fonte: Elaborada pelo autor. 


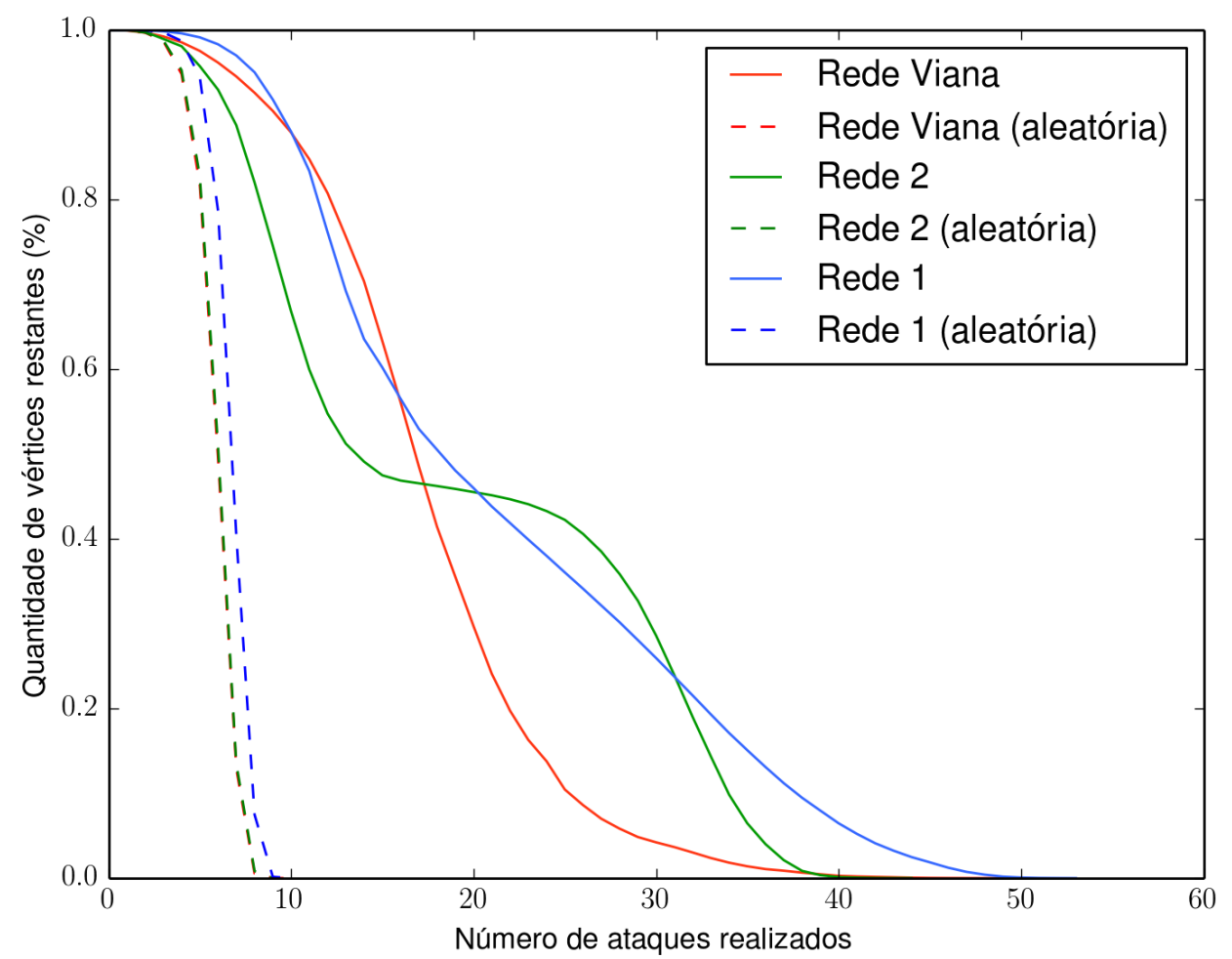

(a)

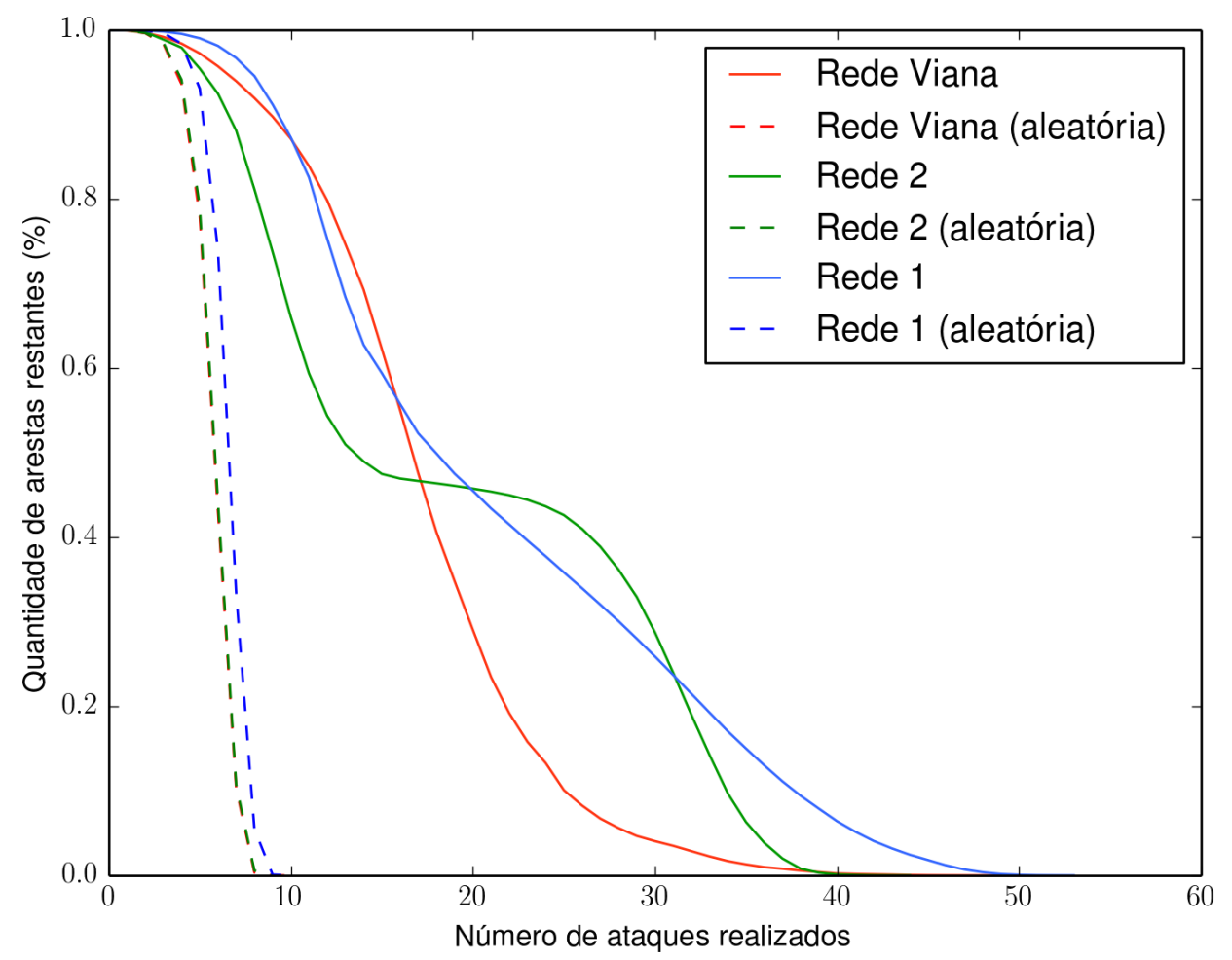

(b)

Figura 3.32 - Ataques em cascata.

Fonte: Elaborada pelo autor. 


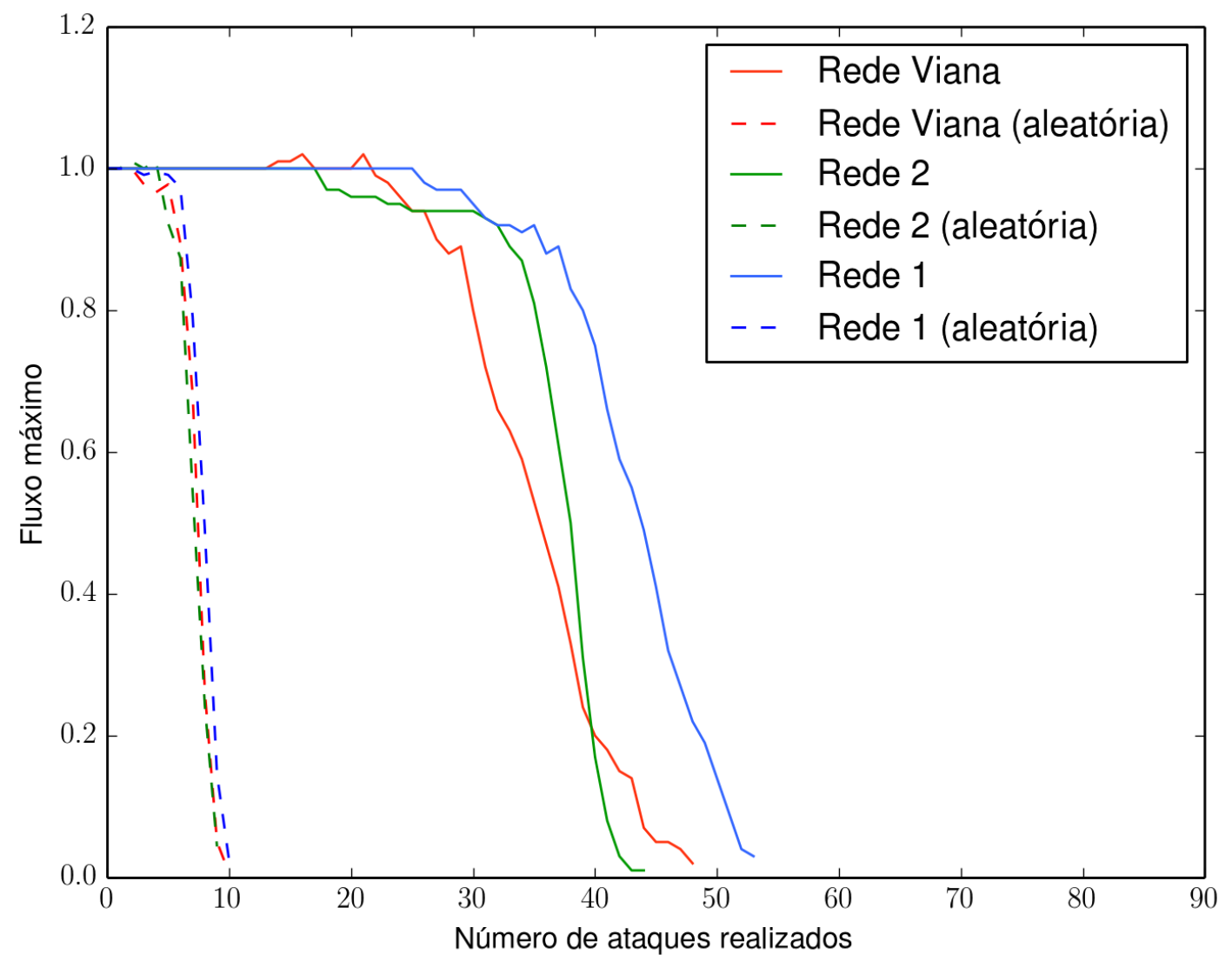

Figura 3.33 - Fluxo máximo.

Fonte: Elaborada pelo autor. 


\subsection{Comunidades}

Para identificar as comunidades presentes em um grafo $G(\vartheta, \varepsilon)$ queremos encontrar a configuração que maximiza o valor de $Q$ (vide seção 2.3.6). Para isso começamos com um grafo $H(\vartheta, \epsilon)$ com $|\vartheta|$ vértices isolados formando um total de $|\vartheta|$ comunidades (note que nesse caso $Q=0$, e $\epsilon=\varnothing$ para o grafo $H(\vartheta, \epsilon))$.

Em seguida buscamos pela aresta $[u, v] \in \varepsilon$ que quando aplicada ao grafo $H(\vartheta, \epsilon)$ produz a maior variação no valor de $Q$. Os dois nós $u$ e $v$ que foram conectados no passo anterior passam a compor uma mesma comunidade e consequentemente teremos um total de $|\varepsilon|-1$ comunidades. Continuamos conectando os nós em $H(\vartheta, \epsilon)$ até que todas as arestas $\epsilon \varepsilon$ sejam aplicadas em $H(\vartheta, \epsilon)$ e consequentemente $\epsilon=\varepsilon$. Ao final definimos as comunidades de $G(\vartheta, \varepsilon)$ como as componentes $H(\vartheta, \epsilon)$ no estado com o valor máximo de $Q$.

Aplicamos o algoritmo acima nas três redes de canais, os resultados estão na tabela 3.34.

Tabela 3.34 - Resumo para o quantidade de vértices, quantidade de arestas e valência média de cada rede.

\begin{tabular}{l|ccccc} 
& $\begin{array}{c}\text { Número de } \\
\text { grupos }\end{array}$ & $\begin{array}{c}\text { Tamanho do } \\
\text { menor grupo }\end{array}$ & $\begin{array}{c}\text { Tamanho do } \\
\text { maior grupo }\end{array}$ & $\begin{array}{c}\text { Tamanho médio } \\
\text { dos grupos }\end{array}$ & $\begin{array}{c}\text { Modularidade } \\
\text { máxima }\end{array}$ \\
\hline Rede 1 & 65 & 9 & 1522 & 392.292 & 0.922911 \\
Rede 2 & 51 & 11 & 422 & 122.569 & 0.9142 \\
Rede Viana & 61 & 9 & 410 & 81.36 & 0.9385
\end{tabular}

Fonte: Elaborada pelo autor.

As três redes apresentam aproximadamente a mesma quantidade de grupo apesar da diferença de tamanho entre ela (a rede 1 posssui $30 \%$ mais grupos que a rede Viana apesar de ser 5,1× maior). Além disso, todas as redes apresentam um grupo muito pequeno da ordem de 10 vértices. O tamanho do maior grupo se mostra proporcional ao tamanho total da rede (entre 
$6 \%$ e $8 \%$ do tamanho total da rede). Em todos os casos as redes apresentam uma modularidade aproximada de 0,9. Em (32) Clauset et al. citam um valor de 0,3 como um forte indício de comunidades na estrutura, isso demonstra uma organização altamente modular da rede de canais. 


\section{Capítulo 4}

\section{Conclusões}

Começamos este trabalho propondo um método automatizado para a reconstrução tridimensional dos canais de Havers e Volkmann e para a representação dos mesmo como redes complexas.

Descrevemos todo o procedimento para a obtenção das imagens dos ossos a partir de corte histológico. Em seguida, desenvolvemos um conjunto de procedimentos para processameto de imagens que pode ser aplicado a qualquer conjunto de imagens (outros ossos, células, tecidos) independente do método de aquisição (tomografia, raios-x, etc.) para reconstruirmos a rede de canais de Havers e Volkamann. O método é inteiramente automatizado e diminui o tempo de trabalho, diminui a interferência e possibilidade de erro humano (por cansaço ou repetição), e aumenta significativamente a precisão e qualidade da reconstrução e da rede.

Apresentamos um método para transformar volumes em redes complexas. Ao mesmo tempo mostramos que métodos e medidas consagrados pela literatura de grafos podem ser utilizados para quantificar vários parâmetros da rede de canais. Observamos a preferência pela divisão dicotômica de canais sanguineos pela análise da valência da rede, observamos que as redes são particularmente resistentes a ataques em cascata através do fluxo máximo e do tamanho da rede, e por análise de comunidades mostramos que a redes apresentam uma estrutura altamente 
modular indicando a presença de estruturas com funções específicas.

Mostramos mais um caso onde a representação de um fênomeno por redes complexas é bem sucedida, ratificando o uso de redes complexas como modeladores de fenômenos biológicos. A representação por redes complexas nos permite criar base de dados possibilitando comparar várias redes de diferentes espécimes ou de diferentes ossos. Além disso, uma base de dados nos permite expandir o conjunto de medidas utilizadas, por exemplo podemos utilizar "betweenness" e coeficiente de agrupamento.

Por último, um possível trabalho futuro a ser realizado nessa pesquisar é considerar aspectos geométricos (especialmente o diametro dos canais) da rede de canais incorporando esses aspectos como pesos nas arestas das redes complexas. 


\section{REFERÊNCIAS}

1 VIANA, M. P. et al. Modularity and robustness of bone networks. Molecular BioSystems, v. 5, n. 3, p. 255, 2009. Disponível em: <pubs.rsc.org/en/content/articlepdf/2009/ $\mathrm{mb} / \mathrm{b} 814188 \mathrm{f}>$. Acesso em: 2 set. 2014.

2 COSTA, L. F.; VIANA, M. P.; BELETTI, M. E. Complex channel networks of bone structure. Applied Physics Letters, v. 88, n. 3, p. 033903, 2006. Disponível em: <http://arxiv.org/pdf/q-bio/0412042v1.pdf>. Acesso em: 2 set. 2014.

3 VIANA, M. P. Metodologia das redes complexas para caracterizacao do sistema de Havers, 2007. 109 p. Dissertação (Mestrado em Ciências) — Instituto de Física de São Carlos, Universidade de São Paulo, São Carlos, 2007. Disponível em: <www . teses.usp.br/teses/ disponiveis/76/76132/tde-15032007-135024/publico/tese.pdf>. Acesso em: 18 set. 2014.

4 RÜEGSEGGER, P. et al. Quantification of bone mineralization using computed tomography 1. Radiology, v. 121, n. 1, p. 93-97, 1976.

5 BOIVIN, G. et al. Relationship between bone fluoride content and histological evidence of calcification defects in osteoporotic women treated long term with sodium fluoride. Osteoporosis International, v. 3, n. 4, p. 204-208, 1993.

6 NOGUEIRA, L. et al. 3d histomorphometric quantification of trabecular bones by computed microtomography using synchrotron radiation. Micron, v. 41, n. 8, p. 990-996, 2010.

7 CURREY, J. D. Bones: structure and mechanics. Princeton: Princeton University Press, 2002.

8 JOWSEY, J. Studies of haversian systems in man and some animals. Journal of Anatomy, v. 100 , pt. 4, p. 857, 1966.

9 COSTA, L. F. et al. Analyzing and modeling real-world phenomena with complex networks: a survey of applications. Advances in Physics, v. 60, n. 3, p. 329-412, 2011.

10 COHEN, R. et al. Breakdown of the internet under intentional attack. Physical review letters, v. 86, n. 16, p. 3682, 2001. 
11 RUBINOV, M.; SPORNS, O. Complex network measures of brain connectivity: uses and interpretations. Neuroimage, v. 52, n. 3, p. 1059-1069, 2010.

12 EUBANK, S. et al. Modelling disease outbreaks in realistic urban social networks. Nature, v. 429, n. 6988, p. 180-184, 2004.

13 GURUHARSHA, K. et al. A protein complex network of drosophila melanogaster. Cell, v. 147, n. 3, p. 690-703, 2011.

14 NATIONAL CANCER INSTITUTE. Structure of bone tissue. 2015. Disponível em: <training. seer. cancer.gov/anatomy/skeletal/tissue>. Acesso em: 27 abr. 2015.

15 BELETTI, M. E.; COSTA, L. F.; VIANA, M. P. A comparison of morphometric characteristics of sperm from fertile bos taurus and bos indicus bulls in brazil. Animal reproduction science, v. 85, n. 1, p. 105-116, 2005.

16 COSTA, J. O. et al. Bhalternin: functional and structural characterization of a new thrombin-like enzyme from bothrops alternatus snake venom. Toxicon, v. 55, n. 7, p. 1365-1377, 2010.

17 BRADLEY, O. C. The structure of the fowl. 1915. Disponível em: <www. library. cornell. edu>. Acesso em: 21 set. 2014.

18 OTSU, N. A threshold selection method from gray-level histograms. IEEE Transactions on Systems, Man, and Cybernetics, v. 9, n. 1, p. 62-66, 1979 doi: 10.1109/TSMC.1979.4310076.

19 SUZUKI, S. et al. Topological structural analysis of digitized binary images by border following. Computer Vision, Graphics, and Image Processing, v. 30, n. 1, p. 32-46, 1985.

20 TEH, C.-H.; CHIN, R. T. On the detection of dominant points on digital curves. IEEE Transactions on Pattern Analysis and Machine Intelligence, v. 11, n. 8, p. 859-872, 1989.

21 FRIEL, J. J. et al. Practical guide to image analysis. Materials Park, Ohio: ASM International, 2000.

22 SAGAN, H. Space-filling curves. New York: Springer Science \& Business Media, 2012.

23 COSTA, L. F.; CESAR JUNIOR, R. M. Shape Classification and Analysis: Theory and Practice. Boca Raton: CRC Press, 2009.

24 GONZALEZ, R. C.; WOODS, R. E. Digital Image Processing. Upper Saddle River, N.J Harlow: Prentice Hall, 2007.

25 BONDY, J. A.; MURTY, U. S. R. Graph theory with applications. London: Macmillan, 1976.

26 WEST, D. B. et al. Introduction to graph theory. Upper Saddle River: Prentice Hall, 2001.

27 FORD, L.; FULKERSON, D. R. Flows in networks. Princeton: Princeton University Press, 1962. 
28 EDMONDS, J.; KARP, R. M. Theoretical improvements in algorithmic efficiency for network flow problems. Journal of the ACM (JACM), v. 19, n. 2, p. 248-264, 1972.

29 EDMONDS KARP ALGORITHM. 2015. Disponível em: <en.wikipedia.org/wiki/ Edmonds-Karp_algorithm>. Acesso em: 6 ago. 2015.

30 DINITS, E. Algorithm of solution to problem of maximum flow in network with power estimates. Doklady Akademii Nauk SSSR, v. 194, n. 4, p. 754, 1970.

31 DINIC'S ALGORITHM. 2015. Disponível em: <en.wikipedia.org/wiki/Dinic's_ algorithm>. Acesso em: 6 ago. 2015.

32 CLAUSET, A.; NEWMAN, M. E. J.; MOORE, C. Finding community structure in very large networks. Physical Review E, v. 70, n. 6, 2004. doi: 10.1103/PhysRevE.70.066111.

33 ERDÖS, P.; RÉWYI, A. On random graphs 1. Publicationes Mathematicae, v. 6, p. 290-297, 1959. Disponível em: <renyi .hu/ p_erdos/1959-11.pdf>. Acesso em: 20 ago. 2014.

34 PANORAMA TOOLS. 2014. Disponível em: <panotools. sourceforge. net>. Acesso em: 20 ago. 2014.

35 PANORAMA TOOLS. 2014. Disponível em: <wiki.panotools.org>. Acesso em: 20 ago. 2014.

36 HUGIN. 2014. Disponível em: <hugin. sourceforge.net>. Acesso em: 20 ago. 2014.

37 STACKREG. 2014. Disponível em: <bigwww. epfl.ch/thevenaz/stackreg>. Acesso em: 3 set. 2014.

38 TURBOREG. 2014. Disponível em: <bigwww.epfl.ch/thevenaz/turboreg>. Acesso em: 3 set. 2014.

39 THÉVENAZ, P.; RUTTIMANN, U.; UNSER, M. A pyramid approach to subpixel registration based on intensity. IEEE Transactions on Image Processing, v. 7, n. 1, p. 27-41, 1998. doi:10.1109/83.650848.

40 ThÉVENAZ, P.; RUTTIMANN, U.; UNSER, M. A Pyramid Approach to Subpixel Registration Based on Intensity - erratum. 2014. Disponível em: <bigwww.epfl .ch/ publications/thevenaz9801>. Acesso em: 3 set. 2014.

41 IMAGEJ. 2014. Disponível em: <rsbweb.nih.gov/i j>. Acesso em: 3 set. 2014.

42 PYTHON. 2015. Disponível em: <python. org >. Acesso em: 29 jun. 2015.

43 NETWORKX. 2014. Disponível em: <networkx.github.io>. Acesso em: 24 nov. 2014.

44 NUMPY. 2014. Disponível em: <numpy.org>. Acesso em: 24 nov. 2014. 
45 MATPLOTLIB. 2014. Disponível em: <matplotlib.org>. Acesso em: 24 nov. 2014.

46 MAYAVI. 2014. Disponível em: <mayavi.sourceforge. net>. Acesso em: 24 nov. 2014.

47 CRUCITTI, P.; LATORA, V.; MARCHIORI, M. Model for cascading failures in complex networks. Physical Review E, v. 69, n. 4, p. 045104, 2004. 